\title{
Plant Celluloses, Hemicelluloses, Lignins, and Volatile Oils for the Synthesis of Nanoparticles and Nanostructured Materials
}

Ahmed Barhoum ${ }^{1,2},{ }^{*}$ Jaison Jeevanandam ${ }^{3}$, Amit Rastogi $^{4}$, Pieter Samyn ${ }^{5}$, Yaman Boluk, ${ }^{6}$

Alain Dufresne, ${ }^{7}$ Michael K. Danquah" ${ }^{8,}$ Mikhael Bechelany ${ }^{2 *}$

${ }^{1}$ Chemistry Department, Faculty of Science, Helwan University, Ain Helwan, 11795 Cairo, Egypt.

2 Institut Européen des Membranes, IEM, UMR-5635, Univ Montpellier, ENSCM, CNRS, Place Eugène Bataillon, 34095 Montpellier, France.

${ }^{3}$ CQM - Centro de Química da Madeira, Universidade da Madeira, Campus da Penteada, 9020-105 Funchal, Portugal.

${ }^{4}$ Cytogene Research and Development, Jankipuram, Lucknow, Uttar Pradesh 226021, India. ${ }^{5}$ Applied and Analytical Chemistry Department, Institute for Materials Research, Hasselt University, Agoralaan Gebouw D, B-3590 Diepenbeek, Belgium.

${ }^{6}$ Department of Civil and Environmental Engineering, University of Alberta, Edmonton, Alberta, T6G 2H9, Canada.

7 University of Grenoble Alpes, CNRS, Grenoble INP, LGP2, F-38000 Grenoble, France ${ }^{8}$ Chemical Engineering Department, University of Tennessee, Chattanooga, 615 McCallie Ave, Chattanooga, TN 37403, United States.

\section{Corresponding Author: ahmed.barhoum@science.helwan.edu.eg; mikhael.bechelany@umontpellier.fr}

\begin{abstract}
A huge variety of plants are harvested worldwide and their different constituents can be converted into a broad range of bionanomaterials. In parallel, much research effort in materials science and engineering is focalized on the formation of nanoparticles and nanostructured materials originating from agricultural residues. Cellulose (40-50\%), hemicellulose (20-40\%), and lignin (20-30\%) represent major plant ingredients and many techniques have been described to separate the main plant components for the synthesis of
\end{abstract}


nanocelluloses, nano-hemicelluloses, and nanolignins with divergent and controllable properties. The minor components, such as essential oils, could also be used to produce nontoxic metal and metal oxide nanoparticles with high bioavailability, biocompatibility, and/or bioactivity. This review describes the chemical structure, physical and chemical properties of plant cell constituents, different techniques for the synthesis of nanocelluloses, nanohemicelluloses, and nanolignins from various lignocellulose sources and agricultural residues, and the extraction of volatile oils from plants as well as their use in metal and metal oxide nanoparticles production and emulsion preparation. Further, details about the formation of activated carbon nanomaterials by thermal treatment of lignocellulose materials, few examples of mineral extraction from agriculture waste for nanoparticles fabrication and the emerging applications of plant-based nanomaterials in different fields, such as biotechnology and medicine, environment protection and remediation, or energy production and storage were also included. The review also briefly discusses the recent developments, toxicity, regulations, and challenges of nanomaterials obtained from plant residues.

Keywords: Cellulose; Hemicellulose; Lignin; Plant essential oils; Residues; Nanoparticles; Nanofabrication; Surface functionalization; Applications; Biomedical; Environment; Energy and storage

\section{Introduction}

Plants are widely available throughout the world and offer a wide range of renewable, cheap, non-toxic, and biocompatible nanostructured materials for various industrial applications. ${ }^{1}$ The main components of plant residues (i.e. By-products of farming activities) are cellulose (40-50\%), hemicellulose (20-40\%), and lignin (20-30\%). Proteins, lipids, pectins, sugars, and minerals also are present as minor components that can be extracted (i.e. Phytochemicals) and contribute as reducing and stabilizing agents to nanoparticles (NPs) synthesis..$^{2-4}$ Recently, the demand for plant cellulose, hemicellulose, lignin, volatile oils, and inorganic salts for industrial applications has been increasing as they are non-petroleum material with high biodegradability, carbon neutrality, low environmental risk, and better safety profile for humans and animals compared with chemical compounds. ${ }^{5-9}$ Moreover, 
plants constitute the primary origin of cellulose, hemicellulose, and lignin for the textile industry, ${ }^{10,} 11$ polymer production, ${ }^{12,} 13$ paper making, ${ }^{14,15}$ food packaging, ${ }^{16,} 17$ and drug manufacturing applications. ${ }^{18,} 19$

Nanobiotechnology is a rapidly expanding field worldwide, for the fabrication of nontoxic, sustainable NMs. ${ }^{20}$ Plant extract-based nanoparticle synthesis yields non-toxic nanoparticles, with high bioavailability, biocompatibility, and bioactivity. Considering the wealth of nanomaterials that can be derived from the plants "building blocks" (cellulose, hemicellulose, lignin, and volatile oils), this review aims at describing the various uses of nanocelluloses, nanohemicelluloses, nanolignins, and advanced materials containing oil extracts for synthesizing and stabilizing of metal and metal oxide nanoparticles. ${ }^{21-23}$ Then, the types of nanomaterials that can be synthesized using these extracts, their mechanism of formation, and their potential applications in various fields will be discussed. In complement to previous works, ${ }^{24}, 25$ the present review covers all aspects related to cellulose, hemicellulose, lignin, and volatile oil constituents of core plants in order to be applied as NPs or nanostructured materials (NSMs), from the experimental production set-up to their potential industrial applications. Specifically, this review details the different techniques to design nanocelluloses, nanohemicelluloses, nanolignins, their types and classifications, and their specific physicochemical properties, toxicity and regulations, bulk and surface functionalization for tailored applications. In order to further improve and broaden their application and commercialization in different fields, novel routes in the future of research in nanocelluloses, nanohemicelluloses, nanolignins are particularly covered.

In this review, the chemical structure, composition, properties, classification, and application of various agricultural plant residues and non-wood plant residues for nanoparticles and nanostructured materials will be described. First, recent studies on the development of environmentally friendly techniques to produce a broad variety of cellulose nanomaterials will be discussed, such as mesoporous nanocelluloses, thin films with high flexibility, hydrogels, and aerogels. Next, the different types and unique characteristics of hemicellulose and lignin will be presented for the synthesis of nanoparticles, including metal nanoparticles, metal oxide nanoparticles, carbon nanoparticles, and their nanocomposites. Finally, the extraction of volatile oils and their application in the biosynthesis of nanoparticles, the spinning of nanofibers, or control of nano-emulsion properties are 
incorporated. The application of all these nanomaterials in biomedical and healthcare applications, environmental protection and remediation, energy production, food packing, among others, will be highlighted.

\section{Agricultural plant residues}

Agricultural residues are a by-product of different crops. Due to their economic value, it has been suggested that they should be called agricultural residues rather than agricultural wastes. Indeed, these materials regenerated after the process of extracting and making food from different crops could be considered a product with a high valorization potential, especially in countries and regions with limited natural forests to be exploited or that are looking for alternatives to wood material. These residues have structure, composition, and properties similar to those of wood fibers. This makes them suitable for textile, pulp, paper, and composite applications. The demand for agricultural residues as alternatives to woody cellulosic fibers has increased recently due to the environmental concerns of burning the residues, increased awareness of global deforestation, and also because of the low cost of the residues compared to other wood fibers. Agricultural plant residues are broadly classified in non-wood and wood-based plant fibers, depending on the plant parts from which they are obtained as shown in Figure 1. This classification is useful for identifying valuable plant residues (e.g. Plant fibers), and for using them in various applications. 


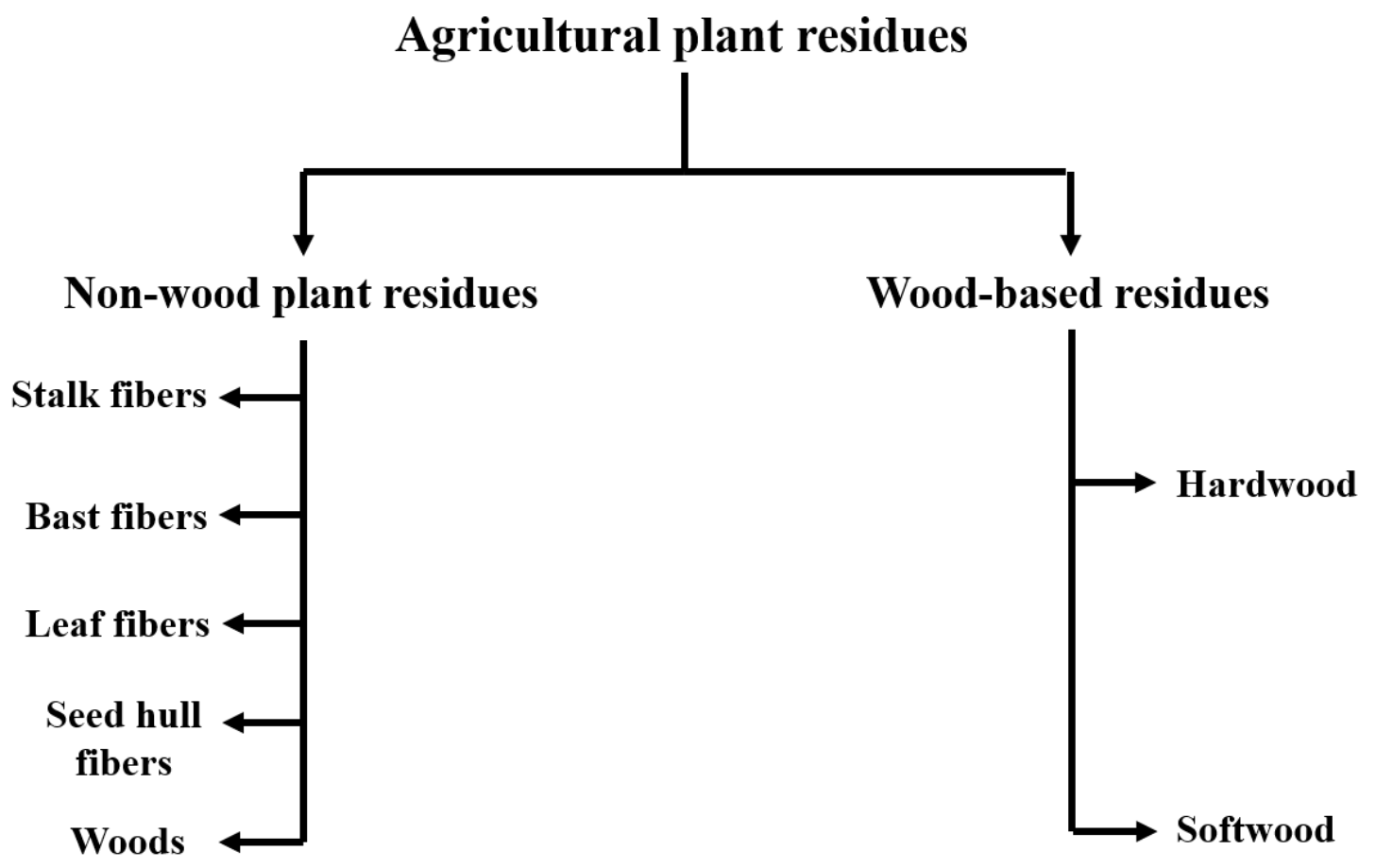

Figure 1. Types of agriculture plant residues

\subsection{Non-wood plant residues}

Non-wood lignocellulosic biomass is abundantly available, cheap, has short harvest cycles, and can be processed easily. Non-wood lignocellulosic biomass can be categorized as agricultural residues, native, and plant fibers. ${ }^{26}$ Non-wood lignocellulosic residues are usually extracted from flowers, leaves, and stalk. The presence of cellulose in the flower cell wall in high percentages plays a crucial role in increasing tissue rigidity and can be removed through biomass processing. The Cirsium horridulum flowers contain about $19-26.5 \%$ of alpha-celluloses distributed in the cell wall of the floral parts (apical and basal style, filament and corolla), ${ }^{27}$ which can be isolated by using the cell wall degradation approach described by Updegraff. The extracts of mono- and oligosaccharide fractions from Apios americana medikus flowers contain 56\% of alpha-cellulose and 36\% hemicelluloses in their cell wall 27 . Moreover, the flowers of Madhuca species, which include M. indica, M. latifolia and M. longifolia, contain $40-47 \%$ of alpha-cellulose in dry weight. ${ }^{28}$ The various lignocellulosic fractions are found in Birdsfoot trefoil, alfalfa, and red clover flowers with respectively 28.7, 14.7 , and $25 \%$ of cellulose, $25.5,13$, and $20.6 \%$ of hemicellulose, and 30, 17.4 and $34 \%$ of lignin as dry weight. ${ }^{29}$ Similarly, Bauhinia variegata flowers contain $12.9 \%$ of hemicellulose in the cell wall. ${ }^{30}$ 
The leaves of floral residues also large quantities of lignocellulosic components. For instance, the stalks of large tobacco leaves contain 30-34\% of alpha-cellulose (determined using the Updegraff and Kurschner-Hanack methods). ${ }^{31}$ Pandanus tectorius leaf extract contains $37.3 \%$ of alpha-cellulose, $24 \%$ of lignin, $15.7 \%$ of pentosans, $34.4 \%$ of hemicelluloses, and $2.5 \%$ of extracts. ${ }^{32}$ Moreover, the leaves of the perennial grass Lolium perenne contain 22.7$36.8 \%$ of cellulose, whereas each cellulosic fraction contains about $61.7-71.6 \%$ of glucose. The leaves were lignin-free with the presence of $28.4-38.3 \%$ of residual hemicelluloses. ${ }^{33}$ Lignocellulosic biomass is also present in other plant parts, such as seeds, ${ }^{34,35}$ and fruits. ${ }^{36,37}$

\subsection{Wood-based residues}

Wood consists of tissues made mainly of cellulose, but also contains lignin, halfcelluloses, and other peptic materials together with various carbohydrates. The live sections of wood contain significant biological substances and materials stored in cells, such as starch, semisynthetic materials, sugars, and fats. The wood dead sections contain the remains of the nitrogenous living matter, and sometimes unused stored materials, such as dyes, resin materials, and oils, in large quantities. Wood lignocellulosic biomasses generally contain 35$50 \%$ of celluloses, $20-35 \%$ of hemicelluloses, and $10-25 \%$ of lignin, as well as proteins, oils, and ash as residual functional components. ${ }^{38,39}$ Table 1 lists the chemical composition and main constituents of various wood types including hard- and softwood. 38,39

Table 1. Chemical composition of lignocellulosic wood biomass 38 OElsevier (2010) and 39 OElsevier (2012).

\begin{tabular}{|l|c|c|c|c|}
\hline $\begin{array}{c}\text { Lignocellulosic } \\
\text { biomass }\end{array}$ & $\begin{array}{c}\text { Plant } \\
\text { Name }\end{array}$ & $\begin{array}{c}\text { Cross and } \\
\text { Bevan cellulose } \\
\mathbf{( \% )}\end{array}$ & $\begin{array}{c}\text { Hemicellulose } \\
\mathbf{( \% )}\end{array}$ & $\begin{array}{c}\text { Total lignin } \\
\mathbf{( \% )}\end{array}$ \\
\hline Hardwood & Poplar & $50.8-53.3$ & $26.2-28.7$ & $15.5-16.3$ \\
\hline Hardwood & Oak & 40.4 & 35.9 & 24.1 \\
\hline Hardwood & Eucalyptus & 54.1 & 18.4 & 21.5 \\
\hline Softwood & Pine & $40.0-50.0$ & $24.0-27.0$ & 20.0 \\
\hline Softwood & Douglas fir & 44.0 & 11.0 & 27.0 \\
\hline Softwood & Spruce & 45.5 & 22.9 & 27.9 \\
\hline
\end{tabular}


The organization of different polymers as found in the cell wall of trees and plant parts is schematically represented in Figure 2. The cell wall surrounds the other plant cell organelles. The cell wall consists of an interlinked polymer network of polysaccharides and glycoproteins that become organized into a complex order during their biosynthesis. ${ }^{40}$ The primary wall develops in the early stage of the plant cell life and is made of different polysaccharides, including cellulose. Specifically, it is a structure of cellulose with glycans as a cross-linker. Depending on the cross-linker type, equal amounts of glucan and xyloglucan may be contained within a pectin matrix (Type I primary wall), or glucuronoarabinoxylans are present in absence of pectin or structural proteins (Type II primary wall). ${ }^{41}$ The core components of the secondary wall, which is formed after the plant cell has completed growth, are lignin, cellulose, and hemicellulose. Only some plant cell types contain inferior (secondary) walls for additional support, defense, or water conduction. The primary cell wall is composed of a few layers, and it is considered to be a rather flexible structure.42, 43 Conversely, the secondary cell wall is thicker and the presence of ordered cellulose structures provides more rigidity.

Cellulose fibrils are directly synthesized near the plasma membrane, while the matrix polysaccharides are enzymatically formed through glycosyltransferase reactions. ${ }^{44}$ The identification and analysis of a broad range of poly- and monosaccharides in plant cells and cell walls has been possible by the development of advanced analytical methods, such as gas chromatography-mass spectroscopy, 45 and Raman microspectroscopy ${ }^{46}$. However, more studies are needed to determine the molecular mechanisms of polysaccharide assembly and how their biosynthesis are regulated. ${ }^{47}$ The cellulose in fibril form is composed of a bundle of extremely thin elementary fibers that are ordered in a matrix with supplementary polysaccharides and lignin. Crystalline cellulose fibrils can be visualized in the cell wall using spectroscopy and microscopy techniques. ${ }^{48}$ 


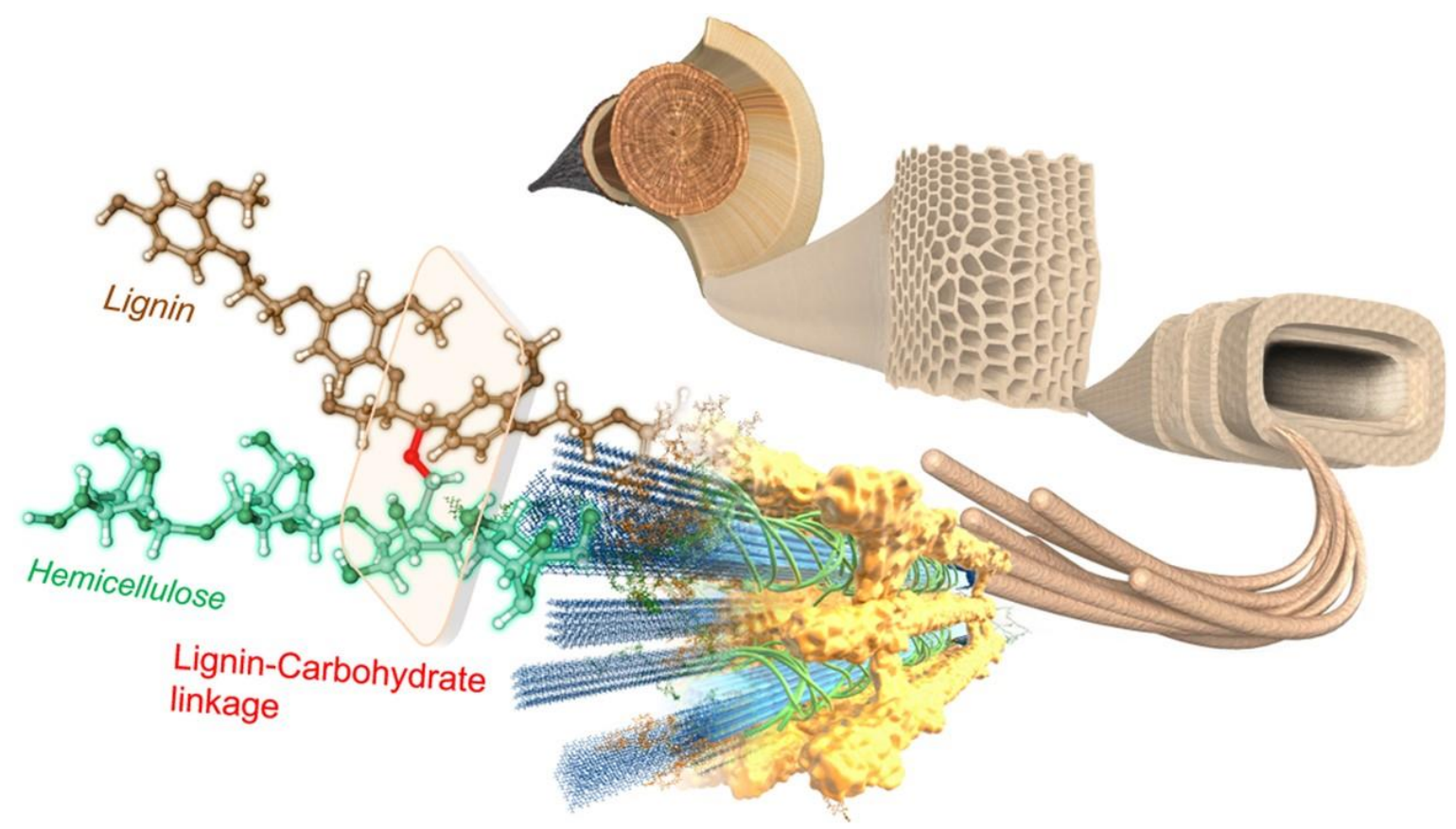

Figure 2. The plant cell wall as an ordered polymer structure at a molecular scale. The singlecell wall with primary and secondary wall layers and bundle of cellulose microfibrils surrounded by lignin and hemicellulose matrices. @ Nature, 2018.

\section{Cellulose and Cellulose-Based Nanomaterials}

Cellulose was discovered by Anselme Payen in 1838 who described its chemical formula and Staudinger delineated the structure of the cellulose polymer in 1920.50-55 Cellulose is an essential material in the plant cell wall in order to maintain the mechanical properties of plant stiffness and strength. Cellulose can be considered as a completely natural and renewable biopolymer that can be obtained from agricultural/crop residues and forest biomass residues. ${ }^{56} \mathrm{It}$ is organic in nature $\left(\mathrm{C}_{6} \mathrm{H}_{10} \mathrm{O}_{5}\right)_{\mathrm{n}}$, and contains a linear backbone of beta (1-4) linked D-glucose units (see Figure 3). In its primary form, the natural occurrence of celluloses corresponds to a cellulose I structure with high crystallinity. In its alternative form, the celluloses can be regenerated from solution processing and have a different structure of cellulose II. As the transition of cellulose, I into cellulose II is irreversible, both structures are metastable and highly stable. Supplementary edifices, such as cellulose III and IV, can be obtained through various chemical treatments. ${ }^{57}$ Cellulose is made of carbon (44.4\%), hydrogen (6.1\%), and oxygen (49.4\%). Usually, cellulose from plant origin is found in 
mixtures with hemicellulose, pectin, lignin, and other elements. Conversely, cellulose extracted from other sources, such as microbes, is quite pure with high water content and high mechanical strength due to the elongated chains. ${ }^{58}$ In general, the cellulose has no taste and odor, is insoluble in most organic solvents, is chiral, and biodegradable.59, 60 It is noteworthy that the first thermoplastic cellulose material was produced in 1870 by the Hyatt Manufacturing Company. Later, the cellulose-based cellophane was developed in 1912, while the regenerated fibers of Lyocell (i.e., rayon) were discovered in the 1980s and are manufactured by spinning from solution. 58

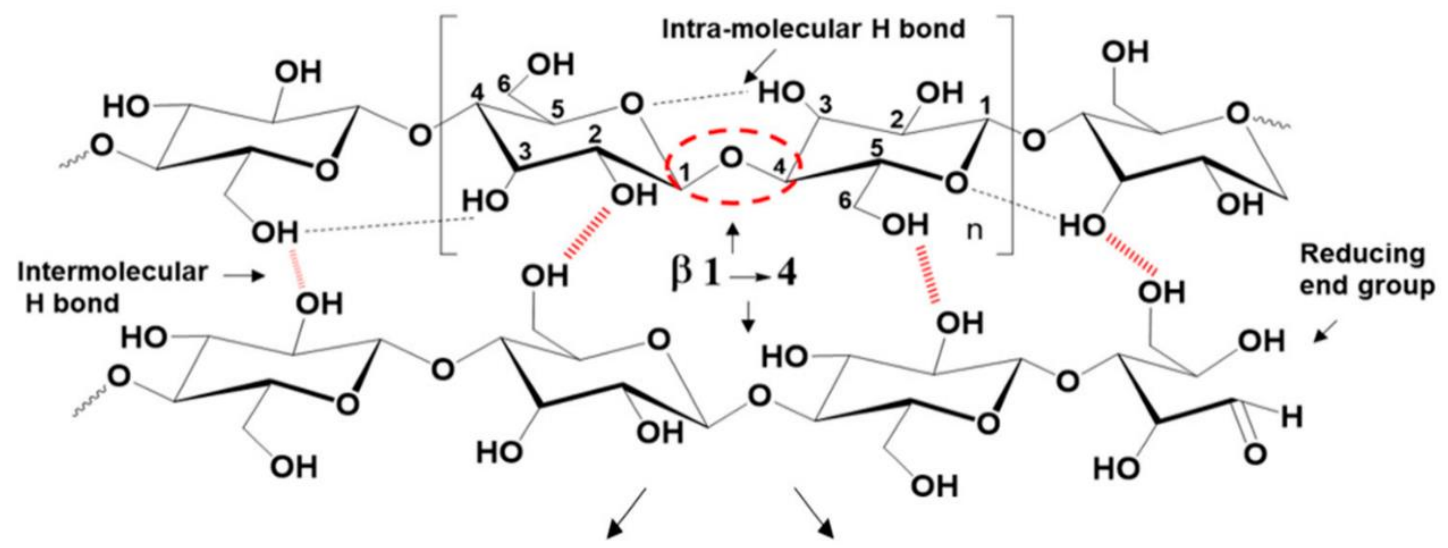

Figure 3. The intrinsic formation of stable cellulose structure through an intra/intermolecular hydrogen bond. reproduced with permission from ${ }^{61}$, 0 MDPI (Basel, Switzerland) (2018).

The most significant sources of cellulose are plants, whereas bacteria and tunicates (sea animals) are used to obtain nanocelluloses..$^{25}$ The selected plant fibers for the production of cellulose can be distinguished according to six main clusters, i.e. Bast, core, grass and reed, leaf, seed, or other fibers. Wood pulp fibers or residual paper fibers are common sources for the conversion into cellulose NMs due to the relatively high purity of cellulose after bleaching, ductility, and excellent physical properties. ${ }^{62}$ The nanocelluoses are favorable for the production of lightweight automotive and aircraft parts, for the reinforcement of building materials and incorporation in high-tech electronics, due to its high strength and stiffness. The excellent barrier properties of nanocelluloses will provide packaging materials that can provide longer life to the foods. Conversely, Bacterial cellulose (BC) has a nanofiber network with higher purity and is suitable to fabricate bio-compatible carrier tissues, vascular grafts, and medical implants. Indeed, the properties and attributes required for these applications 
are available in the building blocks of cellulose, which is the most common structural molecule in nature. Recent studies suggest that plant celluloses can be used to produce various environmentally friendly cellulose-based nanomaterials, including mesoporous cellulose nanostructures, transparent thin films with high flexibility, hydrogels, and aerogel. ${ }^{63}$ Several groups have successfully tested cellulose-based nanomaterials (NMs) for different applications, especially in membranes for batteries, ${ }^{64}$ fuel cells, ${ }^{65}$ ultrafiltration devices, ${ }^{66}$, and biomedical applications. ${ }^{67}$ The different forms of nanocelluloses either from natural sources or bacteria are inherently safe, non-toxic, and "environment friendly" and might revolutionize applications in material and biomedical sciences.

\subsection{Nanocellulose types and classification}

Nanocelluloses are nanomaterials with unique characteristics, including different morphologies, biocompatibility and biodegradability, nano-dimensions geometry, high crystallinity, and low toxicity. The main characteristics are explained by a combination of a large specific surface area and formation of a fiber network with high intrinsic strength and stiffness of the single fibers. ${ }^{68}$ The nanocellulose materials can be divided into various types depending on its appearance, including short crystal-like shapes, long fibrils with micro- or nano-fiber diameters, or spherical particles. ${ }^{69}$ The specific and exclusive properties of the different nanocellulose types and their derivatives are summarized in Table 2, while different morphologies of nanocelluloses are visualized in Figure 4, starting from original cellulose pulp fibers (Figure 4a).

1. Microfibrillated celluloses (MFC) and cellulose microfibers (CMF) are micro-sized fibers that can be obtained from bark, wood, or leaves. The fiber size distribution ranges from several microns to sub-microns, with structured networks and interconnections (Figure 4b). ${ }^{67}$ Generally, MFC and MCF are fabricated using mechanical methods for fibrillation under high shear loads mostly in combination with an enzyme or chemical pretreatment step to improve the accessibility of the fibrils. As a result, the MFC and CMF contain hemicellulose and lignin fractions in different percentages, thus altering their mechanical properties as a function of the fiber type and chemical structure. The obtained material displays a thin, 3D-fiber 
network with crystalline and amorphous regions. MFCs show high yield stress and viscosity, shear-thinning, and water holding capacity. The main MFC and CMF applications are in papermaking and textile industries due to their properties similar to those of engineered fibers and represent an alternative for biocomposites and polymer composites.

2. Nanofibrillated cellulose (NFC) and cellulose nanofibers (CNFs) are cellulose nanofibrils with a high aspect ratio (length to width ratio), in which the fiber diameter ranges from $\sim 5$ to $20 \mathrm{~nm}$ and the length from 0.5 to $2 \mu \mathrm{m}$ (Figure $4 \mathrm{c}$ ). ${ }^{70}$ It is possible to isolate cellulose nanofibrils with lateral dimensions of 3 to $10 \mathrm{~nm}$. Due to their high intrinsic properties (strength of 1 to $3 \mathrm{GPa}$ and crystal modulus of $138 \mathrm{GPa})$, combined with their low density $\left(\approx 1.5 \mathrm{~g} \mathrm{~cm}^{-3}\right)$, they are an attractive material for load-bearing applications. ${ }^{71} \mathrm{CNFs}$ can be produced using mechanical methods (e.g., High-pressure, grinding, homogenization, cryo-crushing and refining) and chemical processes (e.g., Alkali treatment of fibers, steam explosion of alkali-treated fibers, bleaching, and acid treatment). ${ }^{72}$ The CNFs have both amorphous and crystalline parts and present a web-like structure. CNF slurries are viscous and shear thinning aqueous gels with very low dry content (between 2 and $7 \%, \mathrm{w} / \mathrm{w})$. This is one of their two main characteristics, and the other is the ability to form a transparent film once dried. CNFs are more flexible and have a larger surface area than any other fiber type. They are currently fabricated in different dimensions and morphologies for food packaging, tissue-engineering, polymer reinforcement, and pharmaceutical applications.

3. Bacterial cellulose $(B C)$ fibers are typically produced as ribbon-shaped fibrils with a width of $\sim 100 \mathrm{~nm}$ and a diameter of $\sim 2$ to $4 \mathrm{~nm}$, forming an ultra-dense porous network (Figure 4d). Generally, BC fibers can be synthesized from several types of bacteria (most common Gluconacetobacter xylinus and Acetobacter xylinum) and are particularly interesting due to its high yield and purity. The fibrils have interesting inherent properties such as high crystallinity (84-89\%), uniaxial orientation, high elastic modulus ( 78 GPa), elevated water holding capacity, and a high degree of polymerization (up to 8000). ${ }^{73}$ However, BC nanofibrils pack tightly to create a dense mesh, thus limiting the opportunities for cell growth. ${ }^{74}$ Furthermore, BCs 
exhibit a highly planar orientation when compressed into sheets, ${ }^{75}$ and can be disintegrated by some bacterial strains, including Trichoderma viride at $\mathrm{pH} 4.5$ to 6 . Unlike plant-derived NFCs, BC fibers are extremely hydrated and do not require chemical processing for lignin and hemicellulose elimination. ${ }^{76,} 77$ Thus, BC contains pure cellulose without specific functional groups, except alcohol: ${ }^{78-81}$ the BC nanofibers are therefore preferred for critical biomedical applications, especially tissue and bone growth.

4. Nanocrystalline cellulose (NCC), Cellulose nanocrystals (CNCs), or Cellulose nanowhiskers (CNWs) are crystalline cellulose nanoparticles having needle-like morphology with diameters of $\sim 3-7 \mathrm{~nm}$ and length of $\sim 100 \mathrm{~nm}$ (Figure 4e). ${ }^{72}$ The elastic modulus of CNC (up to $140 \mathrm{GPa}$ ) is comparable to CNF because of their high hydrogen-bonding capacity, but the CNCs are less flexible due to their shorter length and higher crystallinity. CNCs are typically produced by acid hydrolysis of the less organized amorphous regions of cellulose that are more susceptible to the catalytic action during the breakdown of glycosidic bonds. Thus, the particles released during hydrolysis of isolated cellulose represent a highly crystalline material. ${ }^{68}$ Unlike BC nanofibers, CNCs are fabricated from many sources, including microcrystalline, hemp, bacterial, wood, and algal cellulose. ${ }^{82} \mathrm{CNCs}$ are gaining interest as reinforcement in polymeric nanocomposites and for membrane applications due to their high surface area and rod-like morphology ${ }^{83}$ Moreover, $\mathrm{CNCs}$ can be grown in precise conditions to form single crystals with high purity. ${ }^{84}$

5. Spherical cellulose nanoparticles (SCNPs) are amorphous or crystalline cellulose nanoparticles with spherical morphology and diameter smaller than $100 \mathrm{~nm}$ (Figure 4f). SCNPs are obtained by acidic or enzymatic hydrolysis of cellulose microfibers, followed by precipitation in water to regenerate the dissolved amorphous cellulose by disintegration using an ultrasound disperser. ${ }^{85}$ Due to their amorphous structure, SCNPs display higher functional group content, good accessibility, better sorption ability, high hydrophilicity, high viscosity, and stabilizing effect on the phase-separation of water dispersions. These particles typically have low polymerization ability and high content of sulfonic groups, and they can be completely hydrolyzed into glucose using enzymes. SCNPs are 
exploited, particularly for the immobilization of therapeutic substances with basic functional groups (due to their high concentration of acidic functional groups), fillers in cosmetics, and medicinal remedies, such as pastes, creams, or sprays for skincare and cure. ${ }^{86}$ Moreover, soft amorphous nanospheres have been produced in an organic solvent-free environment by carboxymethylation of the cellulose II precursor. These nanospheres can be used as toughening additives in composites or supporting materials for catalysis and enzymes. ${ }^{87}$ The unique processing and regeneration of cellulose from ionic liquid with the addition of non-solvent acetonitrile resulted in a uniform amorphous SCNPs without aggregation with good control over moisture content and solvent exchange. .8

6. Cellulose Nanoyarns (NYCs) are fibril-like structures (100 to $1000 \mathrm{~nm}$ in width and over $1 \mu \mathrm{m}$ in length) that are made by spinning the nanocellulose components into continuous fibers using different processes (e.g., Wet spinning, dry spinning, melt spinning or electrospinning). ${ }^{89-93}$ The NYCs are mainly produced from soluble cellulose derivatives such as cellulose acetate and hydroxypropyl cellulose. The cellulose acetate is frequently used with spinning techniques to form nanofibers by deacetylation or bound with other groups for functionalization. ${ }^{94}$ Moreover, the crystallinity strength can be controlled and the cellulose edifice can be transformed (from type I to type II), by modulating the spinning conditions of cellulose in $\mathrm{N}$ methylmorpholine- $\mathrm{N}$-oxide hydrate..$^{95}$ The selection of appropriate solvents and co-solvents is a critical issue that needs to be optimized in parallel with the processing parameters to obtain $\mathrm{CNYs}$ with reproducible sizes and properties. The wet-spinning of CNYs offers promising opportunities to fabricate complex fiber structures and filaments showing high alignment and mechanical strength. ${ }^{96}$ For example, with a coaxial wet-spinning set-up, CNFs can be introduced in a coreshell structure with various shell materials. In this system, the orientation and densification of the CNF core structure can be determined by controlling the coagulation process and interfacial interactions.${ }^{97}$ Alternatively, the wet-spinning of aqueous $\mathrm{CNC}$ suspensions can result in fibers with oriented nanofibers that solidify in a gel-like structure during coagulation. The fiber properties can be enhanced by (2,2,6,6-Tetramethylpiperidin-1-yl) oxyl (TEMPO)-mediated 
oxidation of the CNC surfaces, leading to the formation of additional hydrogen bonds. ${ }^{98}$ The CNCs can be arranged into oriented nanofibers using the wet spinning method (Figure 5), in which continuous fiber yarns are obtained from colloidal cellulose crystals.

7. Cellulose aerogels (CAG) are foam-like materials with an open porous structure and a high specific surface area. They are fabricated by the dissolution of cellulose in a favorable solvent, followed by gelation and the formation of the pore structure, solvent exchange for pore adjustment, and drying. As cellulose coagulation and the formation of a 3D fibrous structure mostly occur during the solvent exchange process, the gelation step is often not necessary. Therefore, immediate drying is performed by freeze-drying or in supercritical $\mathrm{CO}_{2}$ conditions. ${ }^{99}$ Figure 6 shows the schematic representation of the stepwise synthesis approach to fabricate elastic aerogel magnets and stiff magnetic cellulose nanohybrid aerogels. CAGs can be made from natural cellulose sources with a natural network structure (i.e. nanocellulose or bacterial cellulose), regenerated cellulose that is more stable, or cellulose derivatives to fabricate functionalized aerogels. ${ }^{100}$ The gel morphology can be modified by adapting the processing route, solvent systems, and drying conditions to obtain macroporous gels $(\emptyset \geq 50 \mathrm{~nm})$ or mesoporous gels $(2 \mathrm{~nm} \leq \emptyset \leq 50 \mathrm{~nm}) .{ }^{101}$ The solidification is the most critical step that defines the CAG morphology and can be controlled by the phase exchange or isolation of the cellulose chains. The gelation kinetics are influenced through the use of various additives that may simultaneously induce internal cross-linking and functionalization. The sorption properties can be altered by hydrophobization obtained by vapor deposition of methyltrimethoxysilane, ${ }^{102}$ or by plasma modification using trimethylchlorosilane. ${ }^{103}$

8. Anisotropic cellulose nanofibers films (ACF) are highly aligned CNFs that can be fabricated through the direct transformation of an anisotropic wood slice into an anisotropic film by delignification and mechanical pressing approach. This approach allows maintaining the original alignment of CNF in the wood template. ${ }^{104}$ Indeed, during treatment with sodium hypochlorite for lignin removal, the wood macrostructure is not destroyed and retains its well-aligned channel structure. As such, CNFs can be assembled into a film by drying and compression after 
delignification, while hydrogen bonding is induced by the presence of water as structural molecules. ${ }^{105}$ The well-aligned organization of cellulose microchannels in natural wood is also maintained during the in-situ carbonization of wood, possibly in combination with other primary polymer impregnation. ${ }^{106}$ Alternatively, the films with hierarchical alignments of oriented CNFs can also be obtained by direct synthesis of $\mathrm{BC}$, forming long-chain cellulose molecules and nanometer sub-fibrils that are subsequently packed in a highly crystalline parallel orientation. ${ }^{107}$ In general, the alignment of CNFs can be driven by mechanical deformation or shear. In combination with chemical cross-linking, this results in the aggregation into submicron-sized fiber bundles and the formation of a network. ${ }^{108}$ Finally, the CNFs may be aligned by selfassembly in aqueous solution systems through directional control of the cellulose chain aggregation, followed by physical cross-linking of the pre-oriented state and airdrying of the hydrogel 109 .

9. Composite Cellulose Nanoparticles or nanohybrids present additional functionalities through the combination of cellulose with other organic or inorganic materials. The nanocomposite films with controlled mechanical properties can be produced by tuning the ratio of cellulose I and II by partial dissolution of the microcrystalline cellulose powder in a mixture of lithium chloride/N,N-dimethylacetamide.110 The hybrid cellulose aerogels can be fabricated, for instance, by decoration with carbon nanotubes, ${ }^{111}$ silica, ${ }^{112}$ graphene, ${ }^{113}$ or magnetic iron oxide. ${ }^{114}$ CNF coating with silica results in bundles of core-shell hybrid nanofibrils that can be converted, upon freeze-drying, into highly porous silica/cellulose aerogels with higher thermal stability. ${ }^{115}$ The performance of CNF aerogels can be improved by nanocellulose functionalization to form core-shell structures after a uniform silica coating of single fibrils. In this system, cellulose acts as a reaction medium for the in-situ nucleation and growth of condensed silica. ${ }^{115}$ After the burning of the organic cellulose nanofibrils in the core, the silica nanotube aerogels are obtained by using the CNF as an intermediate template.

Table 2. Properties of nanocelluloses and nanocellulose derivatives 


\begin{tabular}{|c|c|c|c|c|}
\hline $\begin{array}{l}\text { Nanocellulos } \\
\text { e derivatives }\end{array}$ & Synthesis method & $\begin{array}{l}\text { Morphological } \\
\text { structure }\end{array}$ & Particle size & References \\
\hline $\begin{array}{l}\text { Microfibrillat } \\
\text { ed cellulose } \\
\text { and cellulose } \\
\text { microfibers }\end{array}$ & $\begin{array}{l}\text { Mechanical } \\
\text { treatment, } \\
\text { enzymatic or } \\
\text { chemical pre- } \\
\text { treatment }\end{array}$ & $\begin{array}{l}\text { Long and thin } \\
3 \mathrm{D} \text { fiber } \\
\text { networks with } \\
\text { crystalline and } \\
\text { amorphous } \\
\text { regions }\end{array}$ & $\begin{array}{l}\text { Wide size } \\
\text { range (micro } \\
\text { to nano sizes) }\end{array}$ & 116 \\
\hline $\begin{array}{l}\text { Nanofibrilate } \\
\mathrm{d} \text { cellulose } \\
\text { and cellulose } \\
\text { nanofibers }\end{array}$ & $\begin{array}{l}\text { Pressure- } \\
\text { incremented } \\
\text { homogenization, } \\
\text { enzymatic and/or } \\
\text { chemical treatment }\end{array}$ & $\begin{array}{l}\text { Consists of both } \\
\text { specific and } \\
\text { accumulated } \\
\text { nano-fibrils. }\end{array}$ & $\begin{array}{l}\text { Length: few } \\
\text { micrometers } \\
\text { Fibril width: } \\
10-100 \mathrm{~nm}\end{array}$ & 117,118 \\
\hline $\begin{array}{l}\text { Bacterial } \\
\text { cellulose } \\
\text { nanofibers }\end{array}$ & $\begin{array}{l}\text { Biosynthesis to } \\
\text { produce bacterial- } \\
\text { based nanocellulose }\end{array}$ & $\begin{array}{l}\text { Ribbon-like } \\
\text { nanofibers }\end{array}$ & $\begin{array}{l}\text { Length: few } \\
\text { micrometers } \\
\text { Diameter: } 20- \\
100 \mathrm{~nm}\end{array}$ & 119,120 \\
\hline $\begin{array}{l}\text { Cellulose } \\
\text { nanocrystals } \\
\text { and cellulose } \\
\text { nanowhiskers }\end{array}$ & $\begin{array}{l}\text { Mechanical } \\
\text { treatment without } \\
\text { acid hydrolysis and } \\
\text { sonication }\end{array}$ & $\begin{array}{l}\text { Crystalline } \\
\text { needle-like } \\
\text { cellulose } \\
\text { particles with } \\
54-88 \% \\
\text { crystallinity }\end{array}$ & $\begin{array}{l}\text { Length: 100- } \\
500 \mathrm{~nm} \\
\text { Diameter: } \\
<100 \mathrm{~nm} \text {; }\end{array}$ & 72 \\
\hline $\begin{array}{l}\text { Spherical } \\
\text { cellulose } \\
\text { nanoparticles }\end{array}$ & $\begin{array}{l}\text { Acidic treatment to } \\
\text { precipitate and } \\
\text { regenerate the } \\
\text { dissolved } \\
\text { amorphous } \\
\text { cellulose }\end{array}$ & Spherical shape & $\begin{array}{l}\text { Diameter: } 50 \text { - } \\
100 \mathrm{~nm}\end{array}$ & 85 \\
\hline
\end{tabular}




\begin{tabular}{|c|c|c|c|c|}
\hline $\begin{array}{l}\text { Cellulose } \\
\text { nanoyarns }\end{array}$ & Electrospinning & $\begin{array}{l}\text { Fibril-like } \\
\text { structures }\end{array}$ & $\begin{array}{l}\text { Length: } \\
\text { Several } \\
\text { microns; } \\
\text { Diameter: } \\
\text { 100-1000 } \mu \mathrm{m}\end{array}$ & 121 \\
\hline $\begin{array}{l}\text { Oriented } \\
\text { cellulose } \\
\text { nanoyarns }\end{array}$ & $\begin{array}{l}\text { Wet spinning of } \\
\text { cellulose } \\
\text { nanowhiskers }\end{array}$ & $\begin{array}{l}\text { Highly oriented } \\
\text { cellulose } \\
\text { nanowhisker } \\
\text { fibers }\end{array}$ & $\begin{array}{l}\text { Length: } \\
\text { Several } \\
\text { microns; } \\
\text { Diameter: 50- } \\
200 \mathrm{~nm}\end{array}$ & 98 \\
\hline $\begin{array}{l}\text { Cellulose } \\
\text { aerogel }\end{array}$ & $\begin{array}{l}\text { Dissolution, } \\
\text { gelation, and } \\
\text { freeze-drying or } \\
\text { supercritical drying }\end{array}$ & $\begin{array}{l}\text { Network } \\
\text { structure }\end{array}$ & $\begin{array}{l}\text { Network } \\
\text { structure } \\
\text { with fiber } \\
\text { diameter: } 50- \\
200 \mathrm{~nm}\end{array}$ & 101 \\
\hline $\begin{array}{l}\text { Anisotropic } \\
\text { cellulose } \\
\text { hydrogel }\end{array}$ & $\begin{array}{l}\text { Dissolution and } \\
\text { controlled } \\
\text { aggregation in gel- } \\
\text { state }\end{array}$ & $\begin{array}{l}\text { Self-assembled } \\
\text { aligned } \\
\text { nanofibers }\end{array}$ & $\begin{array}{l}\text { Aligned fiber } \\
\text { diameter: } 50- \\
200 \mathrm{~nm}\end{array}$ & 109 \\
\hline $\begin{array}{l}\text { Cellulose } \\
\text { nanohybrids } \\
\text { and } \\
\text { nanocomposit } \\
\text { es }\end{array}$ & $\begin{array}{l}\text { Melt extrusion and } \\
\text { casting techniques, } \\
\text { such as hydro- } \\
\text { soluble, emulsion, } \\
\text { and non-hydro- } \\
\text { soluble systems }\end{array}$ & Various shapes & $\begin{array}{l}\text { Length: few } \\
\text { micrometers } \\
\text { Diameter: 50- } \\
200 \mathrm{~nm}\end{array}$ & 122 \\
\hline
\end{tabular}


(a)

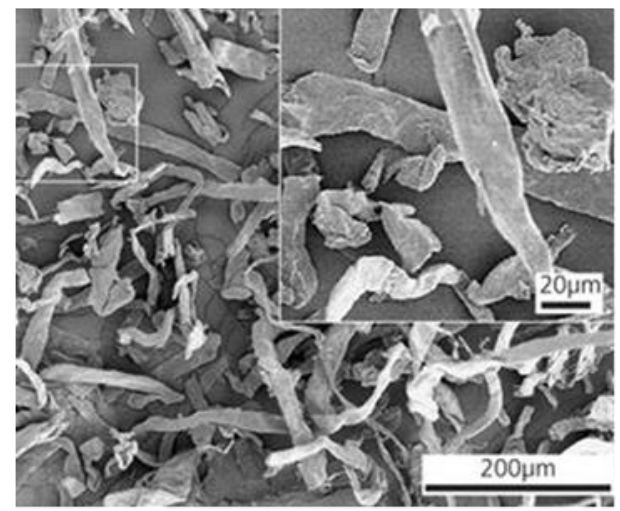

(c)

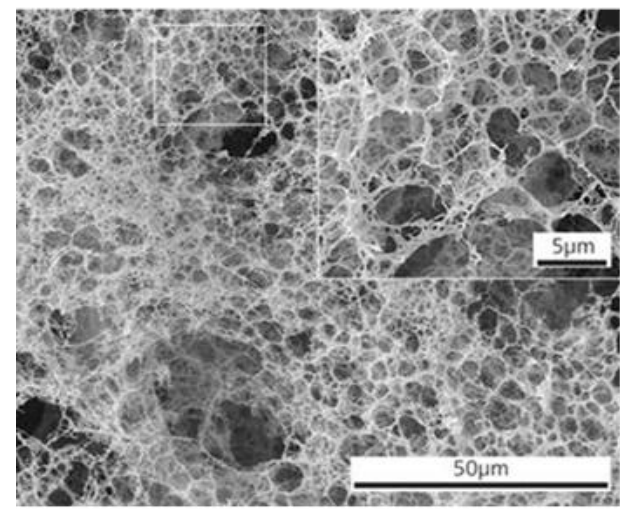

(e)

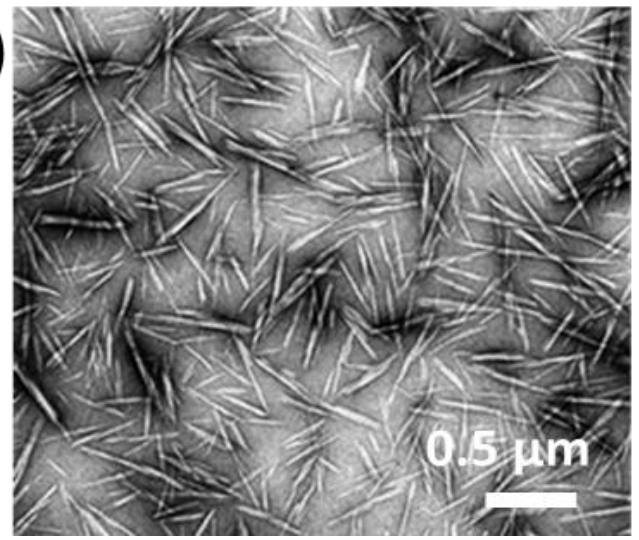

(b)

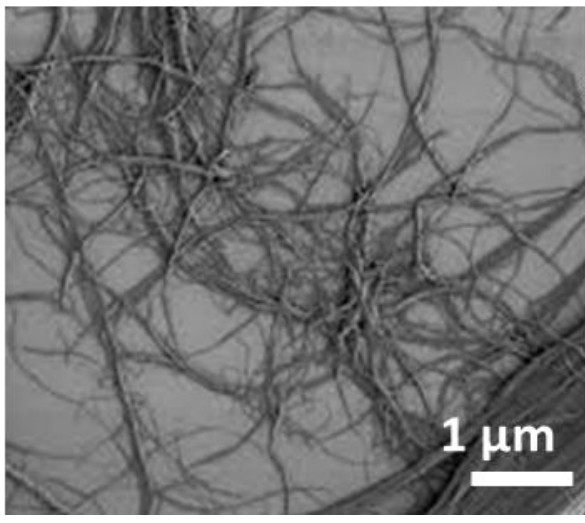

(d)
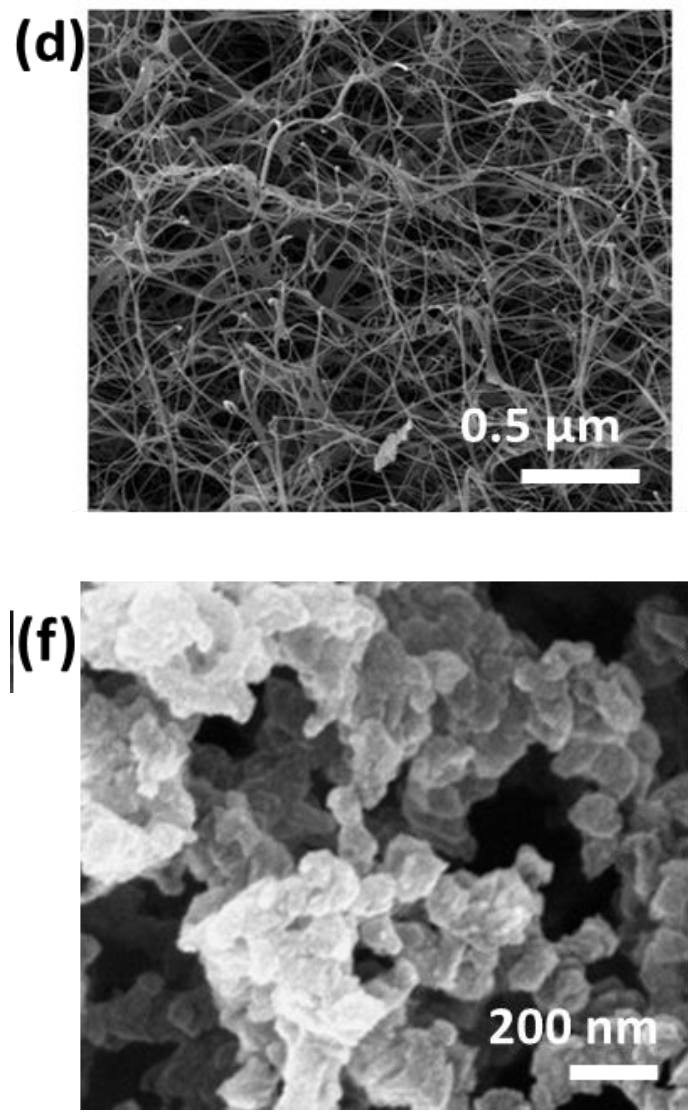

Figure 4. Illustration of morphologies for different forms of cellulose fibers and nanoparticles through scanning electron microscopy (SEM), or transmission electron microscopy (TEM): (a) SEM of cellulose pulp fibers, (b) SEM of microfibrillated cellulose (MFC), (c) SEM of cellulose nanofibers (CNFs), (d) SEM of bacterial cellulose (BC), (e) TEM of cellulose nanocrystals (CNCs), (f) SEM image of spherical cellulose nanoparticles (SCNPs). ${ }^{120-121}$ @Elsevier (2007), @Royal Society of Chemistry (2016). 


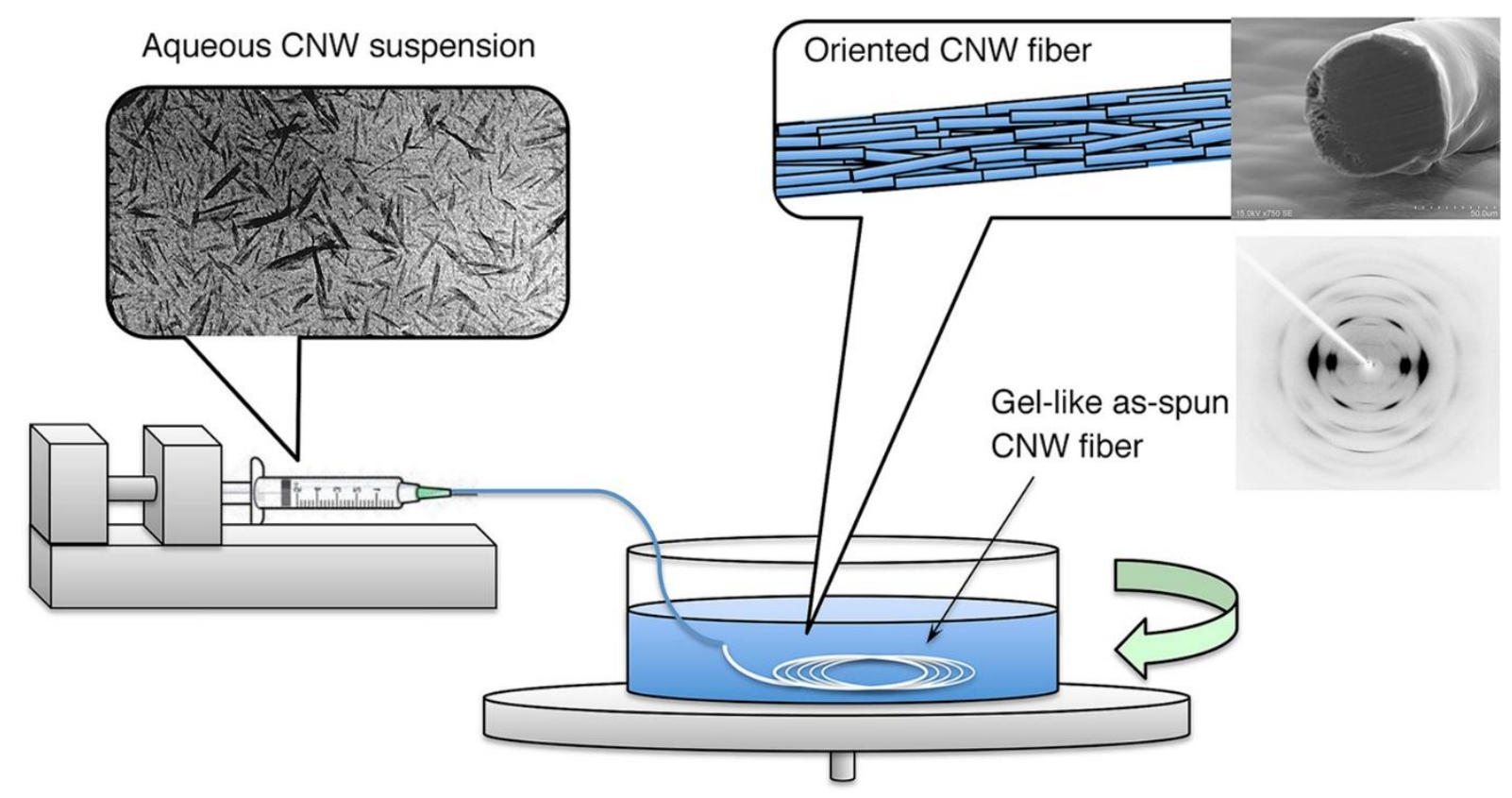

Figure 5. Procedure of wet spinning for cellulose nanocrystals (CNCs) from colloidal aqueous suspension into highly oriented fiber yarns with unidirectional mechanical properties. ${ }^{98}$ @Elsevier (2020).

a 1. Bacterial cellulose hydrogel

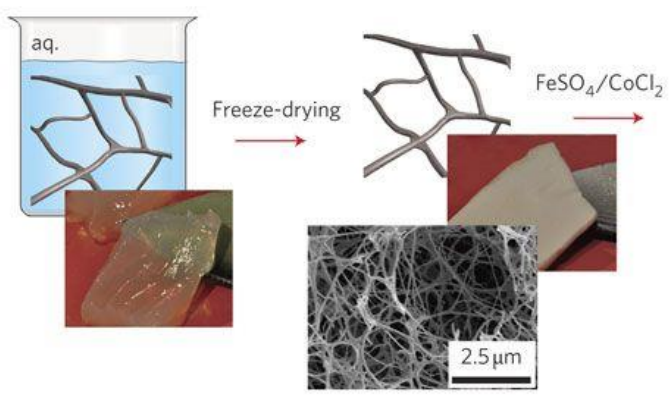

b 5 . Ultraflexible magnetic aerogel

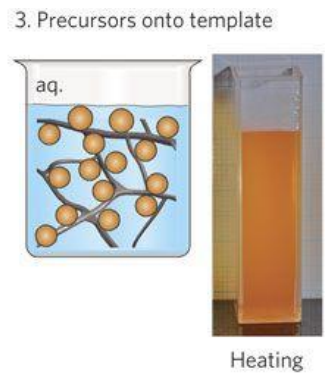

4. Magnetic nanoparticles

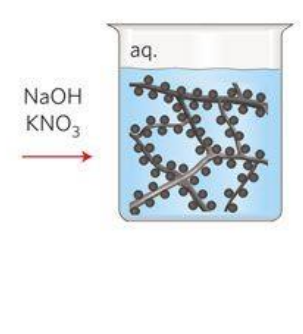

c 6. Stiff magnetic nanopaper
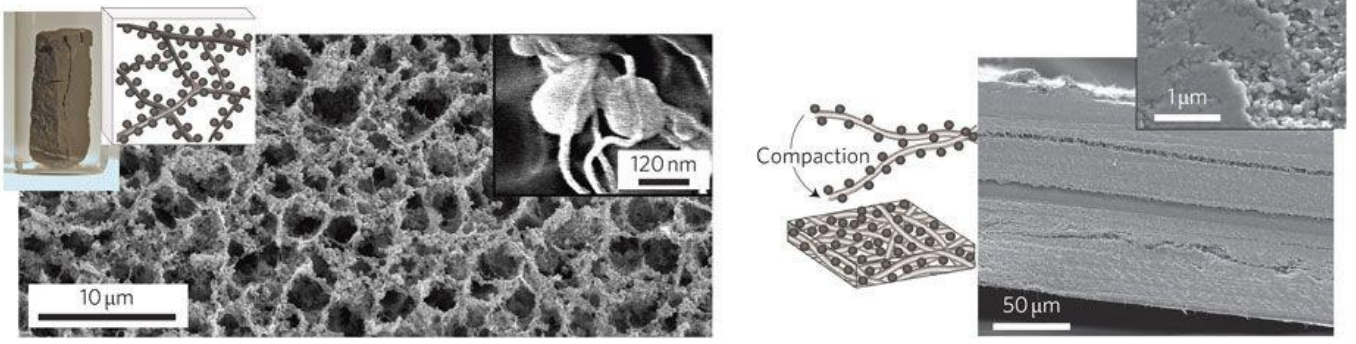

Figure 6. Formulation of cellulose nanohybrid aerogel with tunable elasticity and magnetic properties, including bacterial cellulose (BC) and cobalt ferrite nanoparticles. (a) BC hydrogel produced from Acetobacter xylinum and functionalized with magnetic nanoparticle precipitates, (b) SEM image of freeze-dried magnetic aerogel with $98 \%$ porosity with detail of nanoparticles 
surrounding the nanofibrils (right inset), and schematic drawing of the aerogel (left inset). (c) SEM image of stiff magnetic nanopaper after drying and compression with high magnification image (right inset), and schematic on compacted structure (left inset). ${ }^{123}$ CNature (2010).

\subsection{Nanocellulose fabrication}

Researchers have tested many techniques including mechanical, physical, chemical, and biological treatment for the fabrication of nanocelluloses from a broad variety of plant materials (summarized in Table 2). Cellulose is not only present in plants, but it can also be found in many different species such as marine invertebrate animals (tunicates), bacteria, fungi, and algae. Structure, morphology, and properties of nanocelluloses vary with origin and processing protocols. Thus, it is challenging to produce nanocelluloses with predetermined and constant properties. The creation of cellulose nanomaterials mainly involves two steps: (i) purification or homogenization, and (ii) cellulose material separation to form components of microfibrillar crystals. Generally, two main approaches (bottom-up and top-down) can be followed for the biosynthesis of cellulose nanoparticles, nanocelluloses, and cellulose-based nanomaterials 124,125 .

- Bottom-up approaches in which the nanostructure fabrication starts from a molecularscale material source such as plant-isolated cellulose, to form nanoscale particles of a bigger size, e.g. Self-assembly from a cellulose suspension or precipitation of dissolved cellulose derivatives.

- Top-down approaches where the bulk plant material is pulverized in smaller size particles and cellulose nanostructures are isolated. The three top-down methods are mechanical techniques, chemical hydrolysis, and enzymatic digestion.

In summary, the different methods to fabricate nanocellulose from plant parts are listed in Table 3. The separate production methods are discussed in the following sections, considering the advantages and disadvantages of each method.

Table 3. Production routes of different nanocellulose types from various plant materials

\begin{tabular}{|l|l|l|l|l|l|}
\hline $\begin{array}{l}\text { Final } \\
\text { product }\end{array}$ & Raw Materials & Method & Morphology & Applications & $\begin{array}{l}\text { Referenc } \\
\text { e }\end{array}$ \\
\hline
\end{tabular}




\begin{tabular}{|c|c|c|c|c|c|}
\hline \multirow[t]{5}{*}{$\begin{array}{l}\text { Cellulose } \\
\text { nanoparticle } \\
\text { s }\end{array}$} & Wood pulp & $\begin{array}{l}\text { Mechanical } \\
\text { treatment by } \\
\text { homogenization }\end{array}$ & $\begin{array}{l}\text { Length: 1-2 } \\
\mu \mathrm{m} \\
\text { Diameter: 5- } \\
30 \mathrm{~nm}\end{array}$ & $\begin{array}{l}\text { Environmentall } \\
\text { y friendly } \\
\text { nanoparticles }\end{array}$ & 126 \\
\hline & $\begin{array}{l}\text { Blue agave } \\
\text { bagasse }\end{array}$ & $\begin{array}{l}\text { Chemical } \\
\text { treatment by } \\
\text { organosolv } \\
\text { pulping and } \\
\text { chlorine-free } \\
\text { bleaching }\end{array}$ & $\begin{array}{l}\text { Length: 350- } \\
500 \mathrm{~nm} \\
\text { Diameter: } \\
20-45 \mathrm{~nm}\end{array}$ & $\begin{array}{l}\text { Production of } \\
\text { value-added } \\
\text { products }\end{array}$ & 127 \\
\hline & Wood pulp & $\begin{array}{l}\text { Biological } \\
\text { treatment by } \\
\text { enzymes (e.g. } \\
\text { endoglucanase) }\end{array}$ & $\begin{array}{l}\text { Length: } 5 \mathrm{~nm} \\
\text { Diameter: } \\
\text { 20-30 nm }\end{array}$ & $\begin{array}{l}\text { Surface- } \\
\text { modified } \\
\text { reinforcement } \\
\text { material for } \\
\text { nanocomposite } \\
\text { s }\end{array}$ & 128 \\
\hline & Sisal pulp & $\begin{array}{l}\text { Combined } \\
\text { mechanical } \\
\text { sheering, acid } \\
\text { and enzymatic } \\
\text { hydrolysis }\end{array}$ & $\begin{array}{l}\text { Length: } 150- \\
650 \mu \mathrm{m} \\
\text { Diameter: } \\
20-25 \mu \mathrm{m}\end{array}$ & $\begin{array}{l}\text { Strong } \\
\text { nanocomposite } \\
\text { films for food } \\
\text { packaging and } \\
\text { electronics }\end{array}$ & 129 \\
\hline & $\begin{array}{l}\text { Residues of } \\
\text { cotton fibers }\end{array}$ & $\begin{array}{l}\text { Enzymatic } \\
\text { hydrolysis and } \\
\text { sonication }\end{array}$ & $\begin{array}{l}\text { Spherical } \\
\text { shape }<100 \\
\text { nm }\end{array}$ & $\begin{array}{l}\text { Value addition } \\
\text { to waste }\end{array}$ & 130 \\
\hline \multirow[t]{2}{*}{$\begin{array}{l}\text { Cellulose } \\
\text { nanocrystals }\end{array}$} & $\begin{array}{l}\text { Sugarcane } \\
\text { bagasse }\end{array}$ & $\begin{array}{l}\text { Mechanical } \\
\text { treatment by ball } \\
\text { milling }\end{array}$ & $\begin{array}{l}\text { Average } \\
\text { size: } 148 \mathrm{~nm}\end{array}$ & $\begin{array}{l}\text { Thermally } \\
\text { stable materials }\end{array}$ & 131 \\
\hline & $\begin{array}{l}\text { Seaweed } \\
\text { (Gelidiella } \\
\text { aceroso) }\end{array}$ & $\begin{array}{l}\text { Chemical } \\
\text { treatment by } \\
\text { microwave- } \\
\text { assisted alkali } \\
\text { treatment, }\end{array}$ & $\begin{array}{l}\text { Length: } 408 \\
\mathrm{~nm} \\
\text { Diameter: } 32 \\
\mathrm{~nm}\end{array}$ & $\begin{array}{l}\text { Green polymer } \\
\text { composite } \\
\text { material }\end{array}$ & 132 \\
\hline
\end{tabular}




\begin{tabular}{|c|c|c|c|c|c|}
\hline & & $\begin{array}{l}\text { bleaching, and } \\
\text { acid hydrolysis }\end{array}$ & & & \\
\hline & Cotton linter & $\begin{array}{l}\text { Biological } \\
\text { enzymatic } \\
\text { treatment using } \\
\text { cellulase C and } \\
\text { sulfuric acid } \\
\text { hydrolysis }\end{array}$ & $\begin{array}{l}\text { Average } \\
\text { particle size: } \\
200 \mathrm{~nm}\end{array}$ & $\begin{array}{l}\text { Profitable } \\
\text { oligosaccharide } \\
\text { s }\end{array}$ & 133 \\
\hline & $\begin{array}{l}\text { Eucalyptus } \\
\text { Kraft pulp }\end{array}$ & $\begin{array}{l}\text { Enzymatic } \\
\text { treatment with } \\
\text { endoglucanases } \\
\text { from fungal and } \\
\text { bacterial sources }\end{array}$ & $\begin{array}{l}\text { Length: 400- } \\
600 \mathrm{~nm} \\
\text { Diameter: 6- } \\
10 \mathrm{~nm}\end{array}$ & $\begin{array}{l}\text { Swift } \\
\text { nanocrystal } \\
\text { isolation }\end{array}$ & 134 \\
\hline \multirow[t]{4}{*}{$\begin{array}{l}\text { Cellulose } \\
\text { nanofibers }\end{array}$} & Banana peels & $\begin{array}{l}\text { Mechanical } \\
\text { treatment by a } \\
\text { two-stage high- } \\
\text { pressure } \\
\text { homogenizer }\end{array}$ & $\begin{array}{l}\text { Length: 500- } \\
550 \mathrm{~nm} \\
\text { Diameter: 4- } \\
5 \mathrm{~nm}\end{array}$ & $\begin{array}{l}\text { Non-toxic } \\
\text { reinforcement } \\
\text { composite } \\
\text { material }\end{array}$ & 135 \\
\hline & Jute fibers & $\begin{array}{l}\text { Chemical } \\
\text { treatment with a } \\
\text { nitric } \\
\text { acid/sodium } \\
\text { nitrate mixture }\end{array}$ & $\begin{array}{l}\text { Length: } 100 \text { - } \\
200 \mathrm{~nm} \\
\text { Diameter: } 9 \\
\text { - } 11 \mathrm{~nm}\end{array}$ & $\begin{array}{l}\text { Food packaging } \\
\text { films }\end{array}$ & 136 \\
\hline & $\begin{array}{l}\text { Carrageenan } \\
\text { gel }\end{array}$ & $\begin{array}{l}\text { Biological } \\
\text { treatment by } \\
\text { immobilized } \\
\text { cellulase }\end{array}$ & $\begin{array}{l}\text { Length: } \\
\text { microns } \\
\text { Diameter: } 15 \\
\text { - } 35 \mathrm{~nm}\end{array}$ & $\begin{array}{l}\text { Medicine and } \\
\text { food packages }\end{array}$ & 137 \\
\hline & $\begin{array}{l}\text { Lemongrass } \\
\text { extract }\end{array}$ & $\begin{array}{l}\text { Alkaline } \\
\text { treatment and } \\
\text { enzyme } \\
\text { hydrolysis }\end{array}$ & $\begin{array}{l}\text { Diameter: } \\
\text { 100-105 nm }\end{array}$ & $\begin{array}{l}\text { Nanocomposite } \\
\text {-reinforcing } \\
\text { agent, water } \\
\text { purification, } \\
\text { tissue } \\
\text { engineering, }\end{array}$ & 138 \\
\hline
\end{tabular}




\begin{tabular}{|c|c|c|c|c|c|}
\hline & & & & $\begin{array}{l}\text { and drug } \\
\text { delivery } \\
\text { systems }\end{array}$ & \\
\hline \multirow[t]{4}{*}{$\begin{array}{l}\text { Bacterial } \\
\text { cellulose } \\
\text { nanofibers }\end{array}$} & $\begin{array}{l}\text { Acetobacter } \\
\text { xylinum }\end{array}$ & $\begin{array}{l}\text { Wet drawing and } \\
\text { twisting }\end{array}$ & $\begin{array}{l}\text { Length: } 30 \text { - } \\
50 \mathrm{~nm} \\
\text { Diameter: } 4 \\
-5 \mathrm{~nm}\end{array}$ & $\begin{array}{l}\text { Super strong } \\
\text { and lightweight } \\
\text { nanofibers }\end{array}$ & 139 \\
\hline & $\begin{array}{l}\text { Acetobacter } \\
\text { xylinum }\end{array}$ & $\begin{array}{l}\text { Bacterial culture } \\
\text { and activation } \\
\text { with 3- } \\
\text { methacryoxyprop } \\
\text { y } \\
\text { trimethoxysilane }\end{array}$ & $\begin{array}{l}\text { Macro- } \\
\text { porous } \\
\text { nanostructur } \\
\text { e with a high } \\
\text { surface area }\end{array}$ & $\begin{array}{l}\text { Protein } \\
\text { separation and } \\
\text { hemoglobin } \\
\text { purification }\end{array}$ & 140 \\
\hline & $\begin{array}{l}\text { Gluconacetobacte } \\
\text { r xylinus }\end{array}$ & $\begin{array}{l}\text { Bacterial culture } \\
\text { and extraction }\end{array}$ & $\begin{array}{l}\text { Rod-shaped } \\
\text { microfibril } \\
\text { bundles }\end{array}$ & $\begin{array}{l}\text { Nanofibers in } 7 \\
\text { days }\end{array}$ & 141 \\
\hline & $\begin{array}{l}\text { Acetobacter } \\
\text { xylinum FF-88 }\end{array}$ & $\begin{array}{l}\text { Acetylation and } \\
\text { surface } \\
\text { modification }\end{array}$ & $<500 \mathrm{~nm}$ & $\begin{array}{l}\text { Optically } \\
\text { transparent } \\
\text { composites }\end{array}$ & 142 \\
\hline \multirow[t]{3}{*}{$\begin{array}{l}\text { Cellulose } \\
\text { nanowhisker } \\
\text { s }\end{array}$} & $\begin{array}{l}\text { Microcrystallin } \\
\text { e cellulose }\end{array}$ & $\begin{array}{l}\text { Acid hydrolysis } \\
\text { and acetylation } \\
\text { with vinyl acetate }\end{array}$ & $\begin{array}{l}\text { Length: } 300- \\
350 \mathrm{~nm} \\
\text { Diameter: } 6 \\
-8 \mathrm{~nm}\end{array}$ & $\begin{array}{l}\text { Optical and } \\
\text { electronic } \\
\text { applications }\end{array}$ & 143 \\
\hline & Softwood pulp & $\begin{array}{l}\text { Chemical } \\
\text { treatment by } \\
\text { sulfuric acid } \\
\text { hydrolysis and } \\
\text { bleaching }\end{array}$ & $\begin{array}{l}\text { Length: } 150 \text { - } \\
300 \mathrm{~nm} \\
\text { Diameter: } 4 \\
-8 \mathrm{~nm}\end{array}$ & $\begin{array}{l}\text { Controlled } \\
\text { drug delivery }\end{array}$ & 144 \\
\hline & $\begin{array}{l}\text { Pinewood chip } \\
\text { sawdust }\end{array}$ & $\begin{array}{l}\text { Ethanol } \\
\text { organosolv } \\
\text { treatment with } \\
\text { oxypropylation of } \\
\text { lignin to obtain }\end{array}$ & $\begin{array}{l}\text { Diameter: } \\
300-340 \mu \mathrm{m}\end{array}$ & $\begin{array}{l}\text { Nanocomposite } \\
\text { foams with } \\
\text { high } \\
\text { mechanical and }\end{array}$ & 145 \\
\hline
\end{tabular}




\begin{tabular}{|l|l|l|l|l|l|}
\hline & $\begin{array}{l}\text { reinforced } \\
\text { polyurethane } \\
\text { foam }\end{array}$ & & $\begin{array}{l}\text { thermal } \\
\text { stability }\end{array}$ & \\
\hline
\end{tabular}

\subsubsection{Mechanical disintegration methods}

Mechanical fragmentation is normally used to disrupt the cellulose pulp fibers into smaller particles down to the micro- or nanoscale dimension. The mechanical disintegration is mainly concentrated within the amorphous zones of the microfibrils while leaving the crystal regions strong and intact. Frequently used mechanical methods for the fabrication of fibrillated cellulose materials are aqueous counter collision, cryo-crushing, steam explosion electrospinning, homogenization, refining, and ultrasonication, or a mixture of these methods. ${ }^{83}$ During mechanical processing, the high energy input and the possible creation of suspensions with extremely high viscosity need to be encountered for economic reasons. Figure 7 shows the processes for refining the cork fiber during disk grinding to form CNFs. It is clear from the image that grinding yields CNFs of smaller diameter and disintegrates the cellulose fiber into a CNF structure, while the refining only causes the fibrillation at the fiber surface. ${ }^{125}$

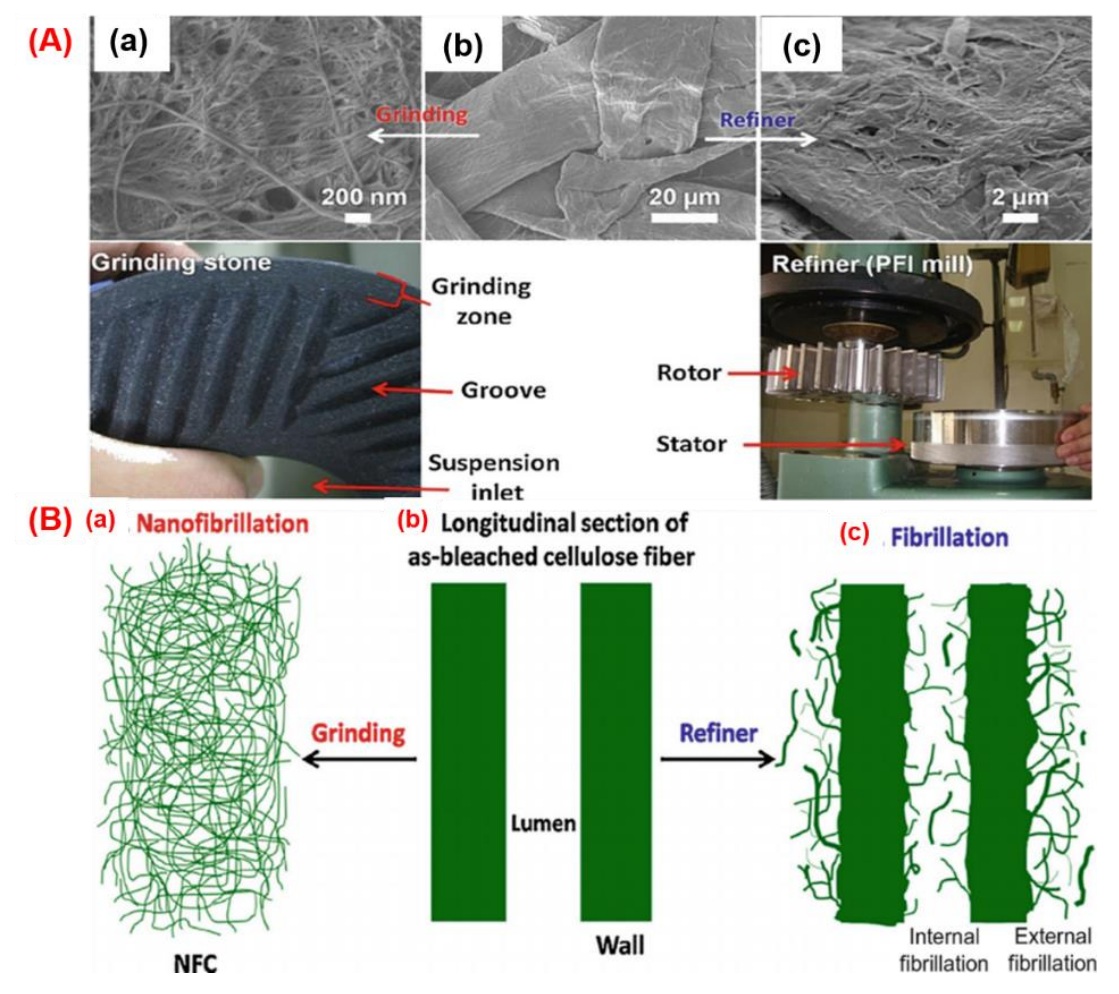


Figure 7. (A) Effect of mechanical processing on fibrillation of the cellulose fiber structure (e.g., Cork fibers) with scanning electron microscopy and (B) Schematic of the fine fiber structure, (a) fibers after disk grinding, (b) as received fibers, and (c) fibers after refining 146, OElsevier (2013).

\subsubsection{Chemical fabrication techniques}

The chemical methods for the fabrication of nanocelluloses can be used as a singlestep or pretreatment step of native cellulose fibers to enable specific accessibility of the cellulose structure (Figure 8). ${ }^{126}$ Various conventional chemical-based pretreatment methods can be used for nanocellulose synthesis, including acid hydrolysis, sulfonation, and ionic liquid approaches. In parallel with the selected chemical treatment and used chemicals, specific functionalities can be incorporated on the cellulose surface. Besides the widespread use of TEMPO-mediated oxidation, the oxidative cellulose sulfonation with periodate and bisulfate is an eco-friendlier route to facilitate the fabrication and functionalization of nanocelluloses with lower ionic charges and the incorporation of additional functional groups. Further, the sulfonation requires less chemicals due to better recycling opportunities and it does not create halogen-containing residues as ecological benefits. Quaternization techniques are used at later stages for providing cationic functionality to the nanocelluloses. ${ }^{83}$

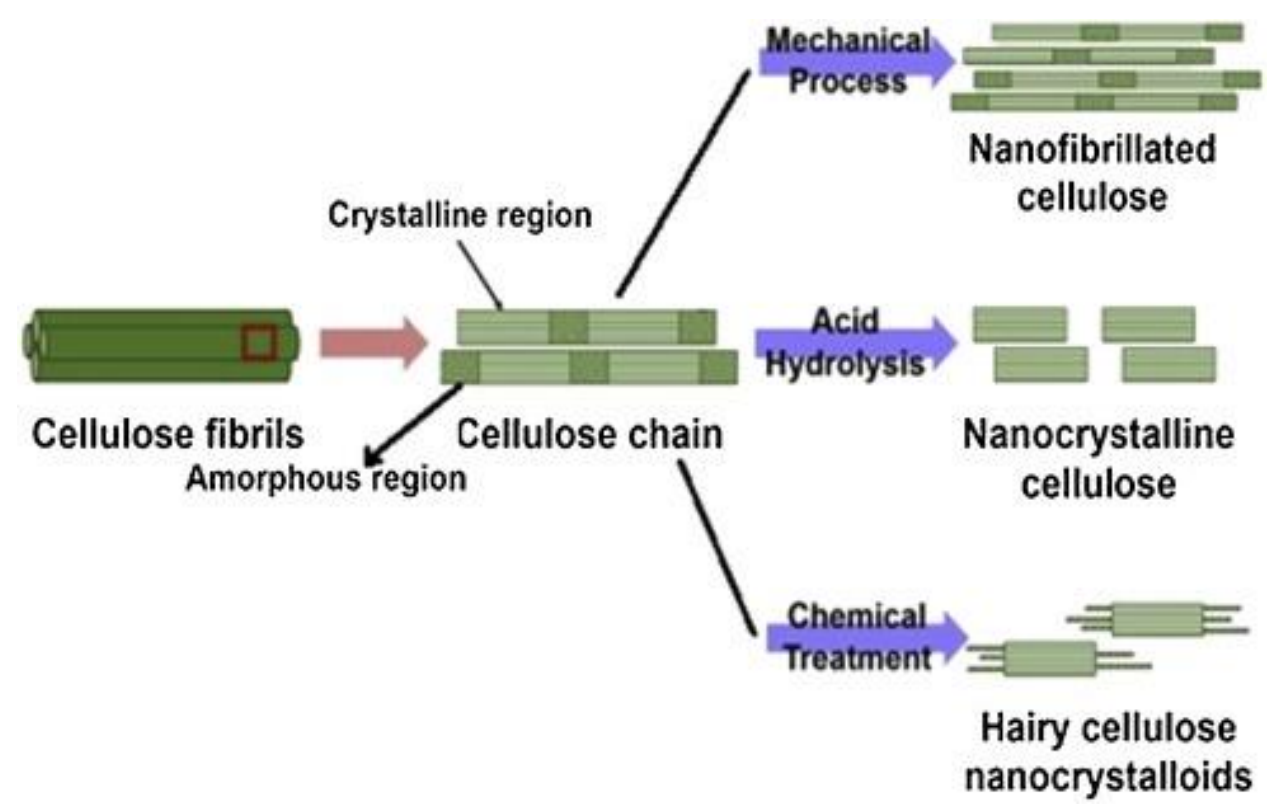

Figure 8. Schematic representation of nanocellulose extraction routes from lignocellulosic biomass combining mechanical and chemical processing steps. ${ }^{147}$ OElsevier (2018). 
The elaboration of cellulose from wood fiber has been established by pulping processes, in order to selectively remove the lignin portions. Soda pulping is used to manufacture wood pulp by treating lignocellulose with sodium hydroxide. The first marketable soda pulping method was developed in 1851, but it is no longer in use. In 1879, sodium sulfate $\left(\mathrm{Na}_{2} \mathrm{SO}_{4}\right)$ was added to soda, and a much stronger pulp was obtained. This procedure is similar to the sulfate process, although it was later discovered that the augmented strength was not due to sodium sulfate, but due to the addition of sodium sulfide $\left(\mathrm{Na}_{2} \mathrm{~S}\right)$. The sulfate process to produce so-called Kraft pulp is currently the main chemical pulping system. The Kraft pulping replaced the traditional soda process, where a combination of sodium hydroxide and sodium sulfide in a mixture of hot water is used as the main chemicals for pulping. The addition of sodium sulfide in Kraft pulping promotes the cleavage of ether and inhibits disagreeable condensation reactions. ${ }^{148}$ During the treatment of wood chips, the linking bonds between lignin, hemicellulose, and cellulose are selectively disrupted. ${ }^{149}$ Specifically, hydroxide and hydrosulfide anions lead to the polymer fragmentation into smaller water/alkali-soluble fragments from which cellulose fibers can be isolated, thus removing approximately $90 \%$ of lignin. ${ }^{150} \mathrm{~A}$ critical limitation of Kraft lignin is its contamination by carbohydrates and some fatty acids in hemicelluloses. ${ }^{151}$ Moreover, a substantial amount of sulfur $(1-3 \% \mathrm{wt})$ is usually linked to the Kraft lignin in thiol via covalent bonds. Kraft lignins are used as dispersants (dye and agrochemical dispersants), ${ }^{152}$ and emulsifiers (asphalt emulsifiers). 153

The further chemical treatment of cellulose fibers through hydrolysis under acidic conditions is used to retrieve $\mathrm{CNC}$, where the amorphous regions are selectively dissolved in favor of the intact crystalline domains. Thus, the entire wood fibers or microfibrils from BC are transformed into CNCs. ${ }^{154,155}$ The latter has been recently used as filler in biopolymer matrices to yield nanocomposites with improved thermal and mechanical properties. In pharmaceutical applications, cellulose derivatives (i.e. Micro-sized cellulose crystals) with high water retention capacity are used as stabilizers, agents to thicken drugs, and for drug tablet reinforcement. 156,157 Recently, several types of ionic liquids were employed for the controlled swelling or full dissolution of cellulose as a primary processing step for nanoparticle formulations. ${ }^{158,159}$ Finally, after the formation of CNFs via chemical processes, 
ultrasonication methods are used to segregate or re-disperse them into individual entities for further incorporation or combination with other materials, as shown in Figure 9.
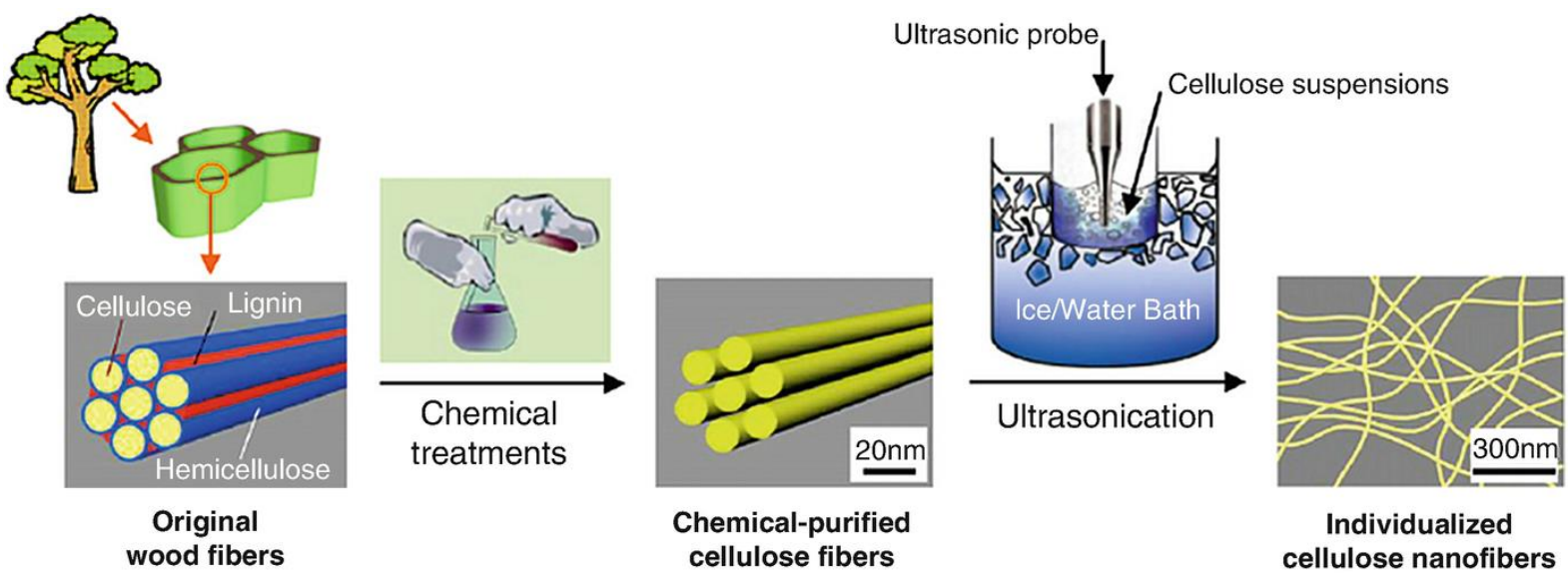

Figure 9. Procedure for the segregation of CNFs from lignocellulose fiber with the effect of ultrasonication on fiber dispersion. ${ }^{160}$ @Elsevier (2011).

\subsubsection{Biological fabrication techniques}

The biochemical reactions involved in the biosynthesis of $\mathrm{BC}$ are very well characterized: they include precise and specifically controlled multi-step processes through the interaction of different enzymes, catalytic, and regulatory protein complexes. ${ }^{161}$ However, the formation of supramolecular structures and molecular mechanisms of glucose polymerization in long and unbranched chains still need to be further investigated. ${ }^{162}$ Schematic representation in Figure 10 illustrates the formation and stabilization of a threedimensional bacterial cellulose biofilm by the foam templating method. The G. xylinus extrudes cellulose that spontaneously migrates toward the air-water interface as the $\mathrm{BC}$ production is influenced by oxygen tension. A suspension of G. xylinus in the growth medium is foamed to construct a bacterial cellulose foam, while the air bubbles are stabilized at the air-water interface with Cremodan. The xanthan is simultaneously added as a thickener to avoid water drainage and enhance the foam stability. During bacterial growth, the foam is progressively stabilized by $\mathrm{BC}$ formation, leading to stable cellulose foam structures in 4 days. ${ }^{163}$ Future research should focus on increasing the stability of nanocellulose fabricated using biosynthesis approaches. Indeed, currently, this limits their large-scale application, compared with chemical synthesis methods. However, biological 
synthesis approaches are widely recommended for nanocellulose fabrication, especially for biomedical applications, because they can yield particles with lower toxicity.
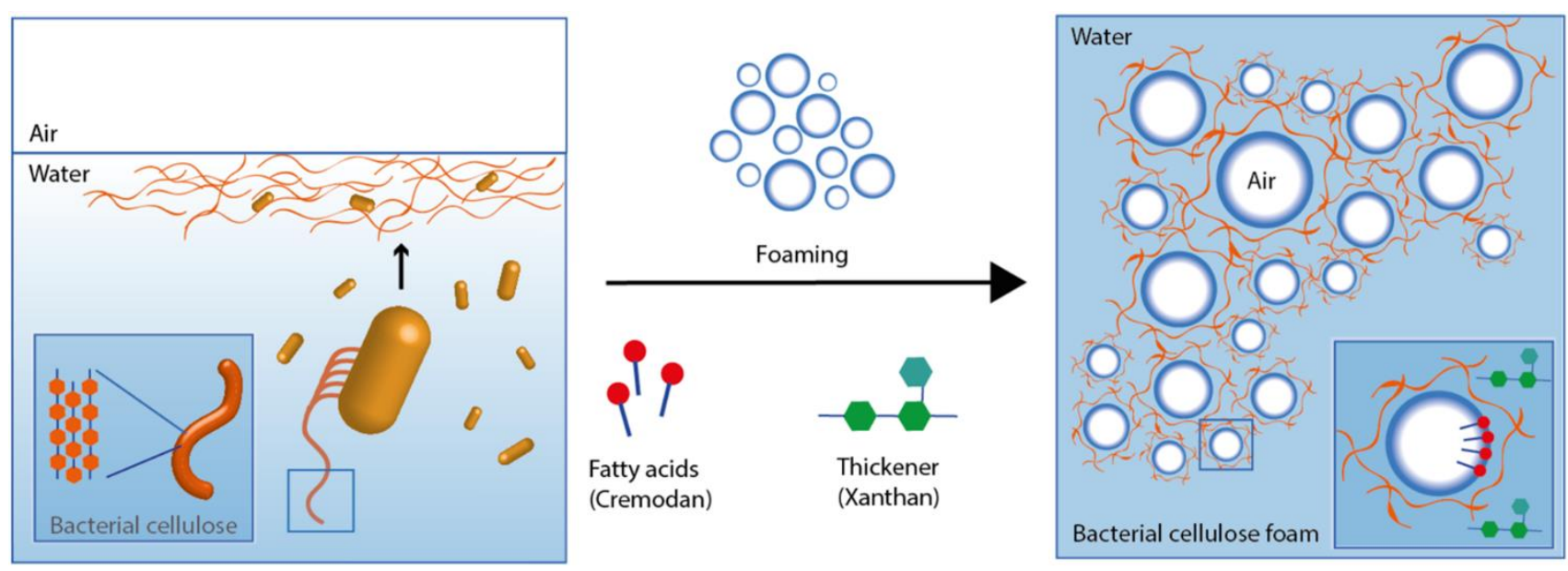

Figure 10. Schematic representation of the formation of 3D bacterial cellulose biofilms and stabilization by foam templating. ${ }^{163}$ ONature (2018).

The enzymatic reactions may enable more favorable synthesis pathways for the fabrication of nanocellulose. Recently, enzymatic hydrolysis have been applied before mechanical cellulose fragmentation. ${ }^{164}$ Enzymatic hydrolysis are considered a supplementary pretreatment step or method to reduce chemical waste and energy consumption. Several enzymes are traditionally used for nanosized cellulose preparation, such as xylanases, cellulases, ligninases, and pectinases. ${ }^{83}$ Moreover, xylanase is used to fabricate nanofibers from chemically-treated banana fibers. Depending on the type of employed enzymes, either the cellulose structure is preferentially degraded (e.g., Cellobiohydrolase), or the native cellulose structure remains intact (e.g. endoglucanase). The use of enzymes generally allows for a milder chemical processing and result in CNFs with a higher aspect ratio. Recently, it has been shown that enzymatically fabricated celluloses can be used to produce CNCs with bigger crystals and compact sulfur content.

\subsection{Emerging Applications of Nanocelluloses}

In the recent times, nanocellulose materials are mainly used in two main categories, either (i) as a reinforcing or filling material into polymers (i.e., As a minor component, e.g., 
Mechanical strengthener), or ii) as a matrix material in combination with other functional materials such as cross-linking agents and functional NSMs to improve their performance (i.e. As a major component, e.g., Membranes). There are numerous mechanical, physical, and chemical techniques to disperse the cellulose nanomaterials into a polymer matrix for the production of nanocomposite materials, which includes melting compounding, injection molding, extrusion, electrospinning, solution casting, in-situ polymerization, and layer-bylayer lamination. ${ }^{69,83}$ Moreover, there are other strategies to prepare novel cellulose-based nanocomposites via casting techniques, such as hydro-soluble, emulsion, and non-hydrosoluble systems. ${ }^{68,82}$ The features of all these composites are dependent on the cellulose nanomaterials network construction. Therefore, cellulose-based nanocomposites show specific and unique mechanical, thermal, and barrier properties. However, enhanced absorption of moisture, limited wettability, discordancy with most polymeric matrices, and limitation of the course temperature are some of the drawbacks of these nanocomposites. Cellulose nanoparticles are excellent environment-friendly nanomaterials that are broadly exploited for the production of novel biopolymer-based composites for industrial applications, as shown in Figure 11 and summarized in Table 4.

The innovative applications of cellulose nanoparticles rely on their exceptional properties and functionality, including elevated aspect ratio, low density, and a hydroxyl reactive side group surface. Nanocelluloses have been used in the following areas (i) nanofillers replace metals and plastics in vehicle manufacture to impart a lightweight and high strength and reduce the cost; (ii) absorbent pads in sensing platforms to help in detection of viruses and biological molecules; (iii) replaces the use of polystyrene-based foams in food packaging material to prevents the spoiling of food contents and entry of oxygen in the food contents; (iv) Food thickener, flavor carriers and suspension stabilizers in food products; (v) strength additive in papermaking industry to improve the fiber to fiber bond strength and acts as a barrier in grease-proof type papers; (vi) wet-end additive in paper making industry to enhance retention; (vii) nanofiller to improve the mechanical properties of rubber latex, thermosetting resins; (viii) fracturing fluid in oil recovery applications; (ix) nanofiller in cosmetics e.g. for hair, eyelashes, eyebrows or nails. (x) nanofiller in the form of tablets for treating intestinal disorders; (xi) filter medium for blood dialysis. Recently, CNCs, BC, CNFs have been used in transparent antimicrobial films, biomedical implants, and also 
as reinforcing polymer fillers and separation membranes. ${ }^{69}, 83$ Moreover, surface modified SCNPs are used in coatings, optically transparent devices, liquid crystals for transparent windows, and watches. CNC-based nanocomposites can be exploited as reinforcing material in food packages, paper industries, light-responsive composites, optical material, in electronic devices, advanced composite-based manufacturing materials, as well as for pharmaceuticals and medical applications. ${ }^{165-171}$ Recently, nanocelluloses have been fabricated and tested for environmental bioremediation, as photocatalysts, adsorbents, membranes, and flocculants. ${ }^{83}$ Moreover, functionalized nanocellulose can be employed for wastewater treatment, biomedical applications, bio-imaging, and catalysis. ${ }^{78,}$, 172-175

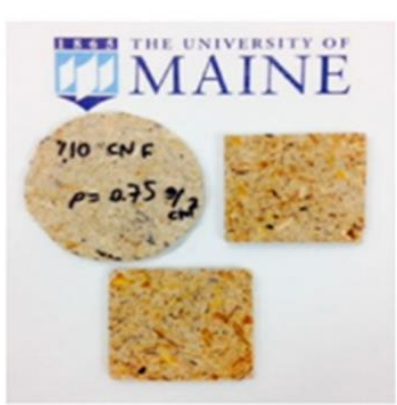

Particle board

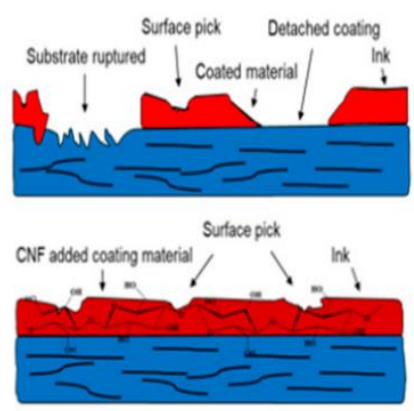

Paper Coating

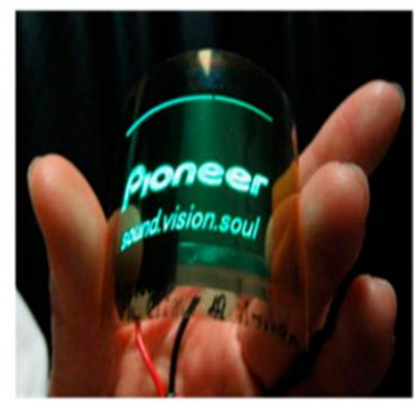

Electronics

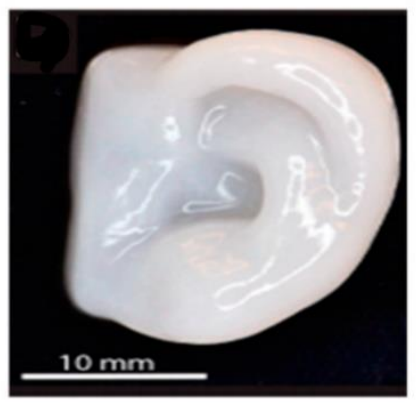

Biomedical

Figure 11. Specific applications of nanocellulose attributed to their exclusive binding nature in (i) particle boards, (ii) paper coating, (iii) electronic devices, and (iv) biomedicine (ear cartilage regeneration). Images labeled as "Electronics" and "Biomedical" are reproduced with permission from 61, CMDPI (Basel, Switzerland) (2018).

Table 4. Significant applications of nanocelluloses. Adapted and reproduced from 176, 177

\begin{tabular}{|c|c|c|}
\hline Field of application & Key application & Reference \\
\hline Electronic devices & $\begin{array}{r}\text { Sensors, windows, electronic (liquid crystal } \\
\text { displays) and optoelectronic materials }\end{array}$ & 178 \\
\hline Construction & Sensors to monitor stress level in bridges & 179 \\
\hline Food packages & Oxygen barrier & 181,182 \\
\hline Food products & Flavor carriers, suspension stabilizers, and \\
& edible celluloses & \\
\hline
\end{tabular}




\begin{tabular}{|c|c|c|}
\hline Paper products & $\begin{array}{l}\text { Grease-proof special paper and artificial } \\
\text { replacement of wood }\end{array}$ & 183 \\
\hline Composites & $\begin{array}{c}\text { To improve the polymer matrix mechanical } \\
\text { properties }\end{array}$ & 184 \\
\hline Oil recovery & Fracturing fluid in oil recovery & 185 \\
\hline $\begin{array}{l}\text { Medical and tissue } \\
\text { engineering }\end{array}$ & $\begin{array}{l}\text { Antimicrobial films, tampons, and sanitary } \\
\text { pads, water-absorbent pads, and wound } \\
\text { dressing }\end{array}$ & $186-188$ \\
\hline Cosmetics & $\begin{array}{l}\text { Composite coating agents for eyebrows, nails, } \\
\text { hair, and eyelashes; stabilizers of emulsions, } \\
\text { such as tonics, conditioners, creams and nail } \\
\text { polishes }\end{array}$ & 189 \\
\hline Automobile & $\begin{array}{l}\text { High strength and lightweight components, } \\
\text { such as side panels, bumpers, and dashboards }\end{array}$ & 190 \\
\hline Textile industry & Tents, sports clothing, and camping equipment & 176 \\
\hline Waste treatment & Oil and miner recycling & 176 \\
\hline Mining and refinery & $\begin{array}{l}\text { Materials for toxic absorption, oil leakage } \\
\text { collecting sponges }\end{array}$ & 176 \\
\hline Communications & $\begin{array}{c}\text { Microphone diaphragms and stereo } \\
\text { headphones }\end{array}$ & 176 \\
\hline Sewage purification & $\begin{array}{l}\text { Water ultrafiltration, urban sewage } \\
\text { purification }\end{array}$ & 176 \\
\hline Energy & Palladium-based membrane fuel cells & 176 \\
\hline Laboratories & $\begin{array}{l}\text { Tissue culture media, protein immobilization, } \\
\text { and chromatographic techniques }\end{array}$ & 176 \\
\hline Biomedical & $\begin{array}{l}\text { Drug delivery, nanofilms, drug excipients, } \\
\text { antimicrobial wound dressing, temporary } \\
\text { artificial skin for ulcers and burns }\end{array}$ & 176 \\
\hline
\end{tabular}

\subsubsection{Biomedical applications of nanocelluloses}


Nanocellulose is considered as the most promising candidate for the biomedical devices, that will be in contact with human cells, due to their intrinsic biocompatibility and biodegradability. ${ }^{191}$ Some uses of nanocellulose in the biomedical field include, BC aerogels in sanitary napkins, tampons, diapers or wound dressings, ${ }^{192}$ composite coating agent in cosmetics for hair, eyelashes, eyebrows or nails, 193 dry filler in the form of tablets for treating intestinal disorders, ${ }^{194}$ absorbent in the rapid test for screening of biological compounds, ${ }^{195}$ filtration membranes for blood dialysis, 196 photoreactive noxious substance purging agents, ${ }^{197}$ matrices for 3D cell culture, ${ }^{198}$ grafting materials for dental implants, ${ }^{176}$ or artificial scaffold substitutes for ligaments and tendons. ${ }^{199}$

Surface of nanocelluloses promotes favorable cellular responses, by favoring cell adhesion and proliferation. Moreover, nanosized cellulose synthesizes novel matrix for tissues, and maintain the appropriate environment, while promoting tissue growth. ${ }^{200}$ Nanocellulose structural properties allow its exploitation as a 'macroscopic' biomaterial or at a smaller 'molecular' scale level. 201 Moreover, the interaction with protein material can be better controlled by the surface functionalization of nanosized cellulose. For instance, a formulation of nanocellulose functionalized with nanosized silver particles has been recently added as an antimicrobial agent in wound dressing, cuffs for nerve surgery, drug delivery, supporting matrix for enzyme immobilization, and cosmetics ${ }^{202}$. BNCs with polysaccharide cellulose can be used for personal care, life sciences, and medicine due to their high purity, absence of hemicellulose and lignin structures, and lack of chemical treatments for their preparation. Therefore, the BC is mainly an interesting material for tissue repair and is currently tested for the development of artificial skin and blood vessels. ${ }^{161}$ In the biomedical field, BC is particularly useful for wound dressings and novel bioactive implants. ${ }^{83}$ The effectivity of BC in biomedical applications was recently confirmed by several clinical trials to improve the ear function, eye lens replacement surgery, and the treatment of allergic rhinitis. ${ }^{203}$ In the future, conventional nanocelluloses might be replaced by three-dimensional printed materials that incorporate nanocelluloses and associated composites as well as stem cells for biomedical applications. ${ }^{204}$

\subsubsection{Environmental protection and improvement}


Simple and ease in the preparation of nanocellulose with different sizes, morphologies, and their easy surface modification provides a vast variety of new materials, composites, films, and gels with fascinating and controllable properties to solve environmental problems and challenges. The combination of analytical science and nanotechnology, particularly, provides smart solutions and green technologies that can circumvent environmental challenges. The nanocelluloses have shown high potential in various fields to improve environmental and climate issues, such as air filtration, drinking water purification, catalytic degradation and removal of hazardous organic pollutants, high capacity absorbents to remove spilled oil from water, highly sensing materials for monitoring waterborne pathogens and organic contaminants. ${ }^{205,206}$ Cellulose nanocomposites coated with metal noble nanoparticles (e.g. Au, Pd, Ag) has been employed as biosensors in many researches. ${ }^{207}$ These studies use the excellent conductivity of noble metal nanoparticles and the network structure of the nanocellulose films to form a flexible electrode to detect analyst species electrochemically. ${ }^{208}$

Future uses of nanocelluloses in wastewater treatment are driven by a fact that less than $1 \%$ of the water in the world is safe to drink, due to pollution or salinity. Consequently, there is an increasing need for clean fresh water. The current water treatment and desalination methods, either chemical or physical, are not economically sustainable, low effectiveness, and environmental harm. The emerging applications of nanocelluloses in ultrafiltration membranes will allow diverting non-potable water sources, such as turbid water, seawater, wastewater, as sources of freshwater. The use of nanocarbon membranes derived from nanocelluloses for treating water is one of the effective nanotechnology solutions. Indeed, these nanofilms are self-cleaning (i.e. No dirt and harmful particles are deposited on them) due to their low viscosity, and this helps to reduce by almost half the amount of energy needed to desalinate water. In parallel, the functionalization of nanocellulose for catalytic purposes is a promising trend for decompositions of organic pollutants in wastewater streams. The nanoparticles for catalytic applications include, e.g. (i) Metal oxide photocatalysts such as $\mathrm{Fe}_{2} \mathrm{O}_{3}, \mathrm{ZnO}, \mathrm{TiO}_{2}$; or (ii) co-catalyst nanoparticles such as $\mathrm{Au}, \mathrm{Ag}$, and Pt. The inorganic-nanocellulose hybrids were introduced as a new photocatalyst type with remarkable properties. For instance, nanocelluloses with embedded metal oxide composites were used as photocatalyst materials to increase the degradation rate of organic 
pollutants as opposed to pure metal oxide materials. Zinc oxide-based nanocomposites are the best example of this catalyst type, showing 79\% of photocatalytic degradation efficiency in 300 minutes. ${ }^{80}$ The nanocellulose materials may act as an ideal substrate with high porosity to incorporate the metal nanoparticles, while simultaneously preventing the aggregation of the catalyst nanoparticles and assisting in the removal of the catalyst nanoparticles after treatment. ${ }^{209}$

Nanocelluloses are used as adsorbent material of residual antibiotics that are normally present in the discharge of industries, and medicinal waste effluents. Nanosized cellulose composites also are efficient adsorbents, for instance, magnetic nanosized celluloses, because they show good performance in eliminating organic pollutants. ${ }^{210,} 211$ Besides, nanocelluloses play a crucial role as absorbent material for the fabrication of environmental sensors ${ }^{212}$. CNFs combined with magnetic nanosized particles is an exceptional composite absorbent. ${ }^{83}$ The pulp of wood-based nanosized celluloses has been used to produce crystals for plummeting 4-nitrophenol and micro-sized microbial and heavy metal filtration membranes. Also, the cotton microfibers have been employed to fabricate CNCs and CNFs adsorbents for the elimination of heavy metals (cadmium and nickel) from wastewaters. Moreover, nanocelluloses can efficiently adsorb heavy metals, dyes, harmful viruses, oils, carbon dioxide, metals, and organic pollutants. Indeed, various nanocellulose types are currently employed for air contaminant adsorption, as wastewater effluent flocculants, and for adsorption regeneration, ${ }^{213}$ as shown in Figure 12.

The benefits and environmental impact of industrial-scale nanocellulose production were assessed by a life cycle analysis of an up-scaled system. It was concluded that largescale produced nanocellulose is a potential material for industrial applications with lower environmental impact, compared with carbon fibers. Moreover, the enzymatic treatment required for nanocellulose synthesis was the main contributor to the environmental friendliness of these materials. ${ }^{214}$ 


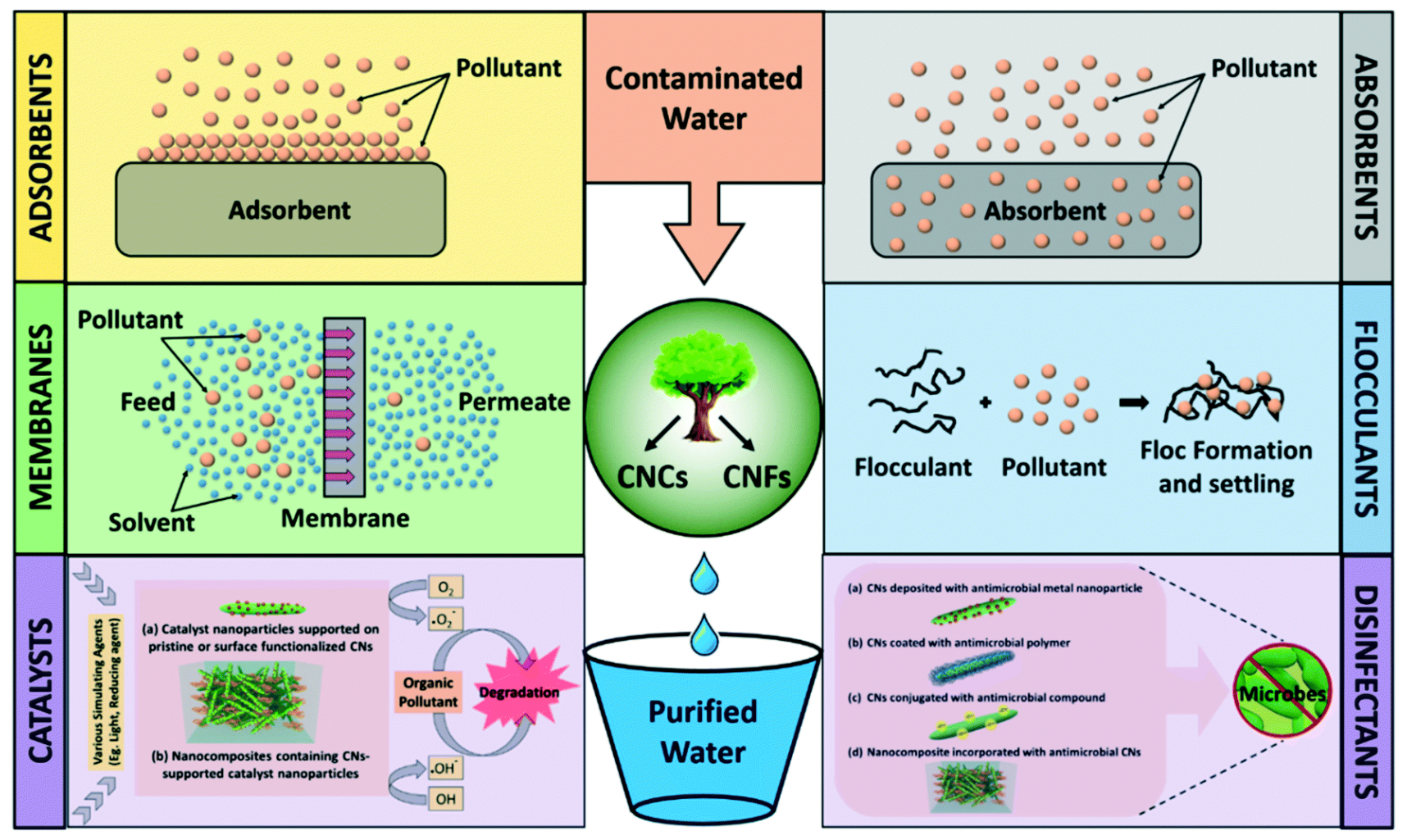

Figure 12. Promising applications of cellulose nanomaterials for water and wastewater treatment with different functionality,215 CRoyal Chemical Society (2018).

\subsubsection{Energy production, conversion, and storage devices}

The solar cells, fuel cells, batteries, and supercapacitors provide promising technologies to revolutionize the energy harvesting and storage in a cleaner way. The emerging applications of nanocelluloses in fabrication electrodes or membranes of the energy devices are a viable contribution towards this objective. There has been significant progress in the utilization of nanocelluloses in the electrochemical energy storage or converting devices, where the material functions as electrodes, separators, electrolytes, or binders. ${ }^{216}$ Moreover, nanocelluloses have been incorporated in fuel cells, solar cells, and nanogenerators. ${ }^{217}$

The advances in practical applications of nanocellulose materials in energy storage applications are summarized in this section, focusing on the production of supercapacitors and batteries made of lithium-ion, lithium-sulfur, and sodium-ion. ${ }^{218}$ Nanocelluloses are also used as a core electrode element, electrolytes, and separator membranes. The nanocellulose aerogels or films are considered as operational substrates for the deposition of electrically conductive films, which form a sheet for electrode and supercapacitor systems as shown in 
Figure 13. ${ }^{219}$ Also, the nanocellulose structure can be used to create 1D, 2D, or 3D bulk electrical energy storage (EES) devices with excellent flexibility. The structures can be incorporated in textile carrier materials for wearable electronics or paper-based EES devices ${ }^{220}$. Furthermore, nanocelluloses can be used as a template for the production of conductive and structured carbon materials via pyrolysis. In parallel, the electrochemical properties of the pyrolyzed nanocellulose can be improved by active functionalization, doping of heteroatoms, and hybridization with other significant materials. ${ }^{216}$ The CNFs with singlewalled nanotube deposits are used to fabricate a unitized separator/electrode assembly as shown in Figure 14, which functions as an excellent cathode and the anode. ${ }^{221}$

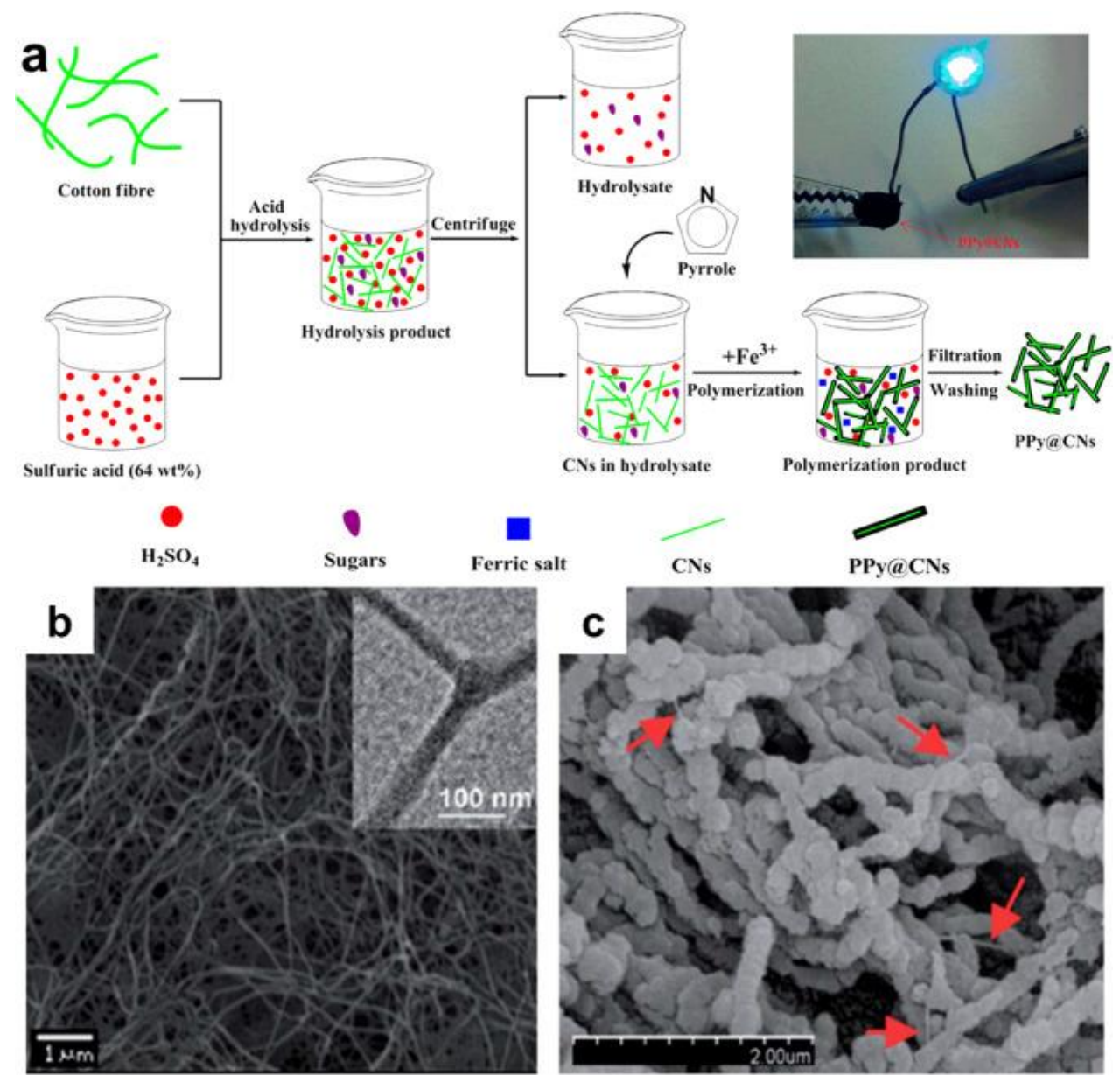

Figure 13. Functionalized nanocellulose-based conductive materials with deposits of polypyrrole and their applications in energy devices functioning as an electrode or supercapacitor. ${ }^{219}$ OElsevier (2017). 


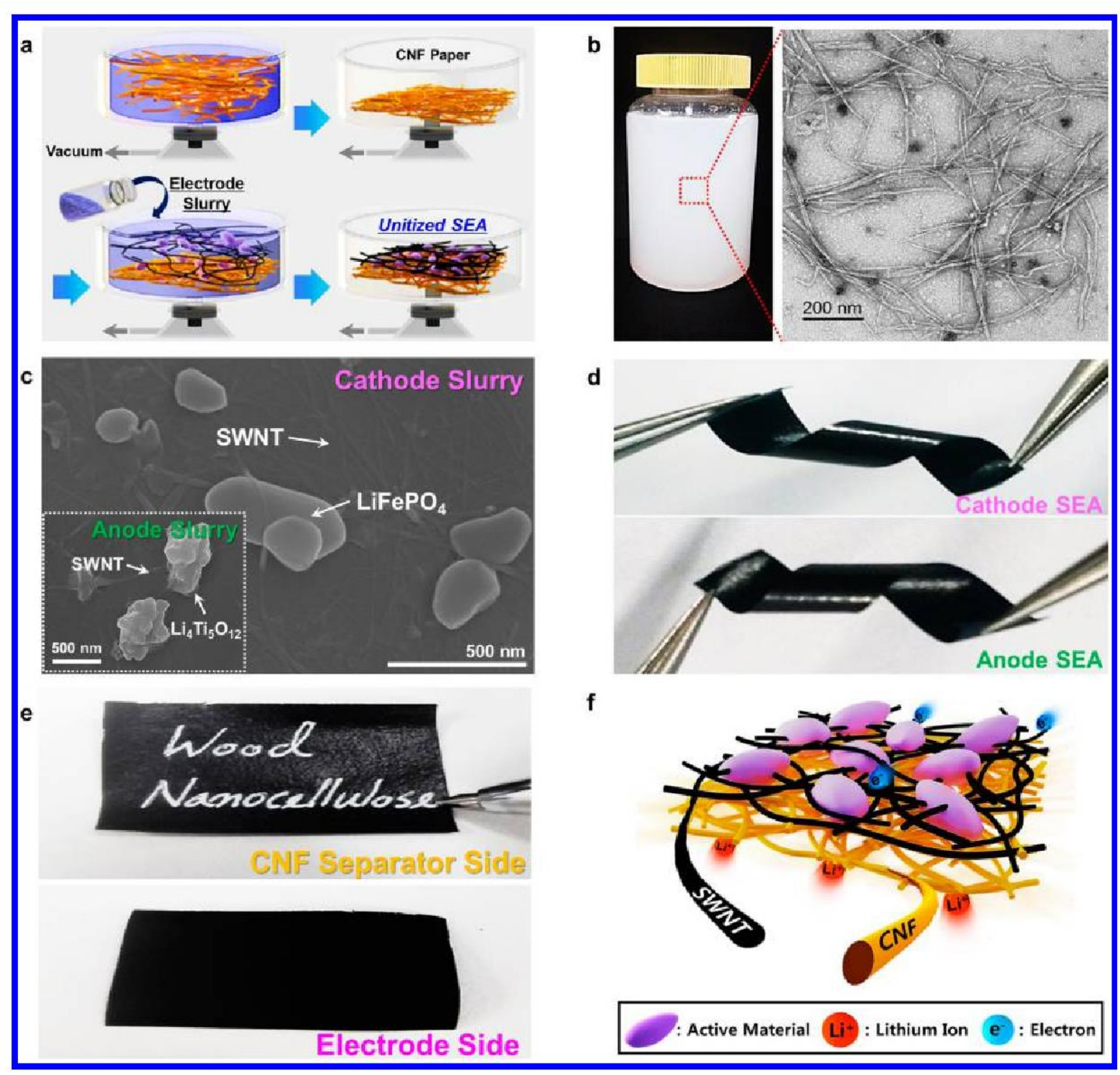

Figure 14. Fabrication of integrated electrode materials as an assembly of CNF (separator material) and single-wall carbon nanotubes (SWNT electrode material). (a) Schematic fabrication procedure for the unitized electrode assembly (b) CNF suspension (left) and a TEM image (right) showing CNFs with nanoscale diameter/length up to a few micrometers. (c) SEM images demonstrating the dispersion state of SWNT and $\mathrm{LiFePO}_{4}$ (or $\mathrm{Li}_{4} \mathrm{Ti}_{5} \mathrm{O}_{12}$ ) powders in the electrode slurries. (d) Self-standing film of flexible $\mathrm{LiFePO}_{4}$ (cathode), and $\mathrm{Li}_{4} \mathrm{Ti}_{5} \mathrm{O}_{12}$ (anode). (e) Two faces of CNF separator (top) and $\mathrm{LiFePO}_{4}$ cathode (bottom). (f) Conceptual illustration for a 1D nanobuilding block (CNF/SWNT)-enabled structural uniqueness of SEAs, 221 CAmerican Chemical Society (2014). 
Supercapacitors have been formed from aerogel-like porous materials with elevated mechanical strength and surface area that can be synthesized in combination with nanocellulose. ${ }^{222}$ The combination of $\mathrm{CNC}$ aerogels with polypyrrole nanofibers provides a flexible energy storage device with good capacitance values during different charging or discharging cycles. ${ }^{223}$ The CNF aerogels with covalent crosslinks display better dimensional stability and preserve their shape under moisture conditions, due to frequent hydrogen bonding in the water-cellulose interface. ${ }^{224}$ Other flexible solid-state aerogel supercapacitors made of CNF with silver and polyaniline nanoparticles have high capacitance, independently of sample bending deformation. ${ }^{225}$ After the carbonization of the nanocellulose material, the excellent structural stability and high conductivity showed by carbon materials (Figure 15), may have substantial applications as supercapacitor electrode materials. ${ }^{226}$ Moreover, doping of the nanocellulose materials and nanocomposites with heteroatoms is expected to lead to a full range of accessible materials for supercapacitors. ${ }^{227}$



Figure 15. Fabrication of conductive hydrogel membrane as an anode with oxygen tolerance to be applied as an implantable glucose fuel cell. (a) Schematic of the platinum nanoparticle/Multiwall carbon nanotube/bacterial cellulose (PtNP/MWCNT/BC) anode. (b) Structure of the glucose fuel cell with PtNP/MWCNT/BC-Pt.228 CRoyal Society of Chemistry (2016).

Fuel cells require the incorporation of conductive membranes, which can be formed by doping of BC membranes with acids yielding with high proton conductivity.229 The proton conductivity can be increased by immersing the $\mathrm{BC}$ film in $\mathrm{H}_{3} \mathrm{PO}_{4}$, and the performance is improved by UV-induced grafting with 2-acrylamido-2-methyl-1- 
propanesulfonic acid. ${ }^{230}$ Ionomer membranes can also be prepared from CNC and CNF through several carriers for charges and sulfuric acid groups, that are present after the acid hydrolysis. 231 Organic solar cells can be immobilized over nanocellulose film substrates, including CNF films with transparent and/or hazy properties ${ }^{232}$. Aerogel membranes can serve as optimum filling of electrolytes and eliminate leakage in dye solar cells. ${ }^{233} \mathrm{~A}$ relative comparison of different nanocellulose substrates showed that the CNC-based devices have better properties than CNF surfaces. ${ }^{234}$ By using transparent nanocellulose paper as a substrate, the flexible perovskite solar cells have been fabricated. 235 However, the water sensitivity of the nanocellulose papers requires an additional coating of acrylic resin to make them waterproof. As such, the modified nanocellulose substrate preserves its morphological stability in water, as illustrated in Figure 16.236 The activity of nanocellulose paper-based solar cells or transparent electrodes can be upgraded either by adding doping materials (e.g., Ag nanowires), or by improving the preparation process (e.g., By increasing the annealing temperature and the number of coating layers).

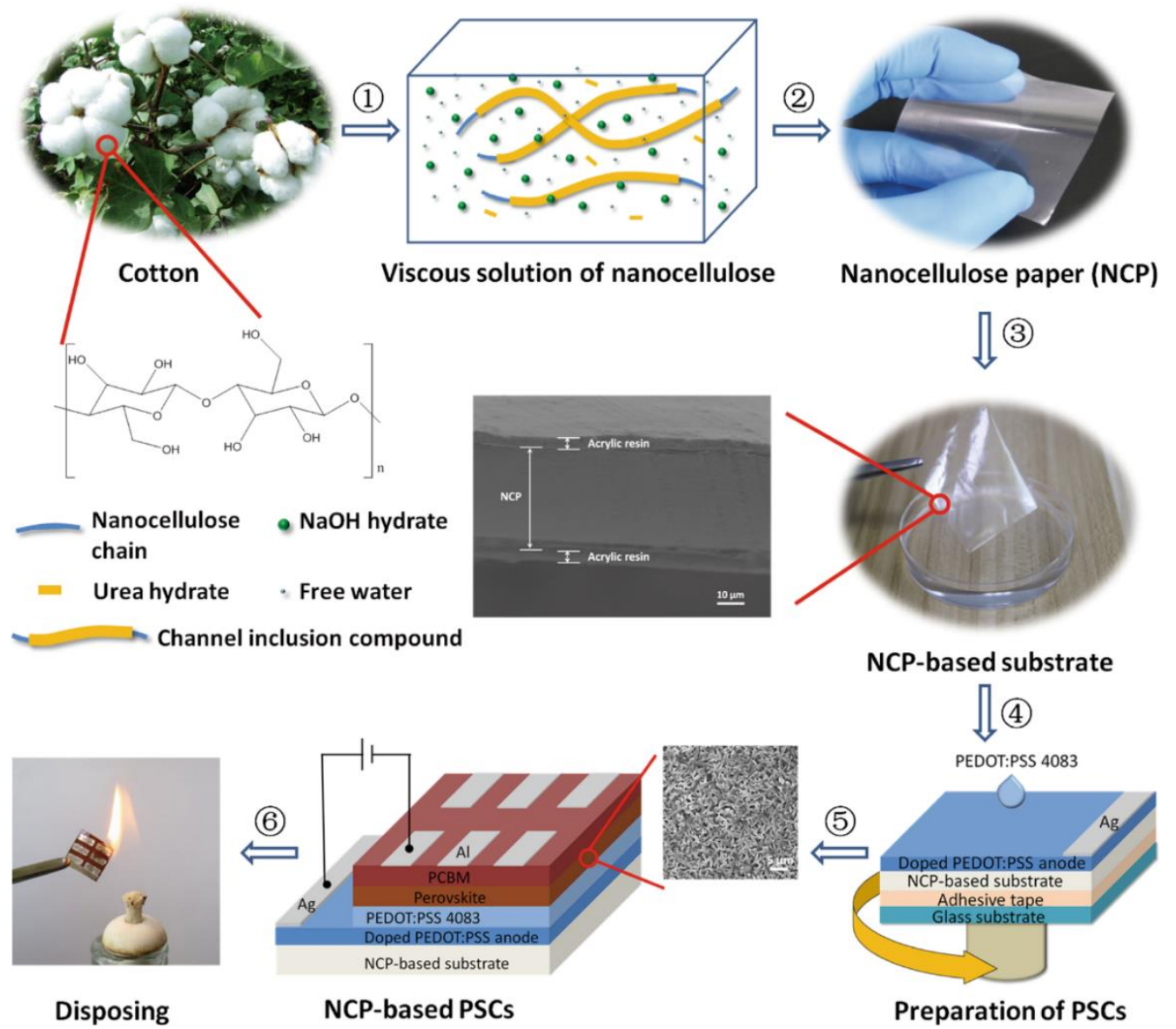

Figure 16. Paper-based perovskite solar cells (PSCs) with nanocellulose paper (NCP) as a substrate. (1) Extraction of nanocellulose from cotton forming a viscous solution. (2) Casting 
the NCP paper substrate. (3) Coating of NCP with acrylic resin to form a hydrophobic surface layer. $(4,5)$ Assembly of different layers in NCP-based PSC. (6) Disposal of flexible and transparent PSC by burning. 236 @Nature (2019).

\subsubsection{Construction Materials}

The nanocellulose is a useful material as reinforcement or functional additive for many construction industries, such as paper manufacture, plastics, food and packaging, textiles, automotive, and aircraft. The nanocellulose composites have been employed under the form of coatings and paints, films, or foams. In paper manufacture, nanocelluloses are expected to provide: (i) dry and wet strength with mechanical reinforcement of the inner paper structure; 237 (ii) gas barrier properties and grease/oil resistance as a coating layer,;238 (iii) retention aid to enhance retention;239 (iv) enhanced surface properties (e.g., smoothness). ${ }^{240}$ However, the processing of nanocellulose suspensions within a coating layer is often limited while using conventional coating techniques, due to the very high viscosity at low fiber concentrations. ${ }^{241}$ Novel coating methods have been created for nanocellulose coatings allowing for better control of the material deposition, using size press, rod coating, spray coating, slot-die coating, and foam coating. ${ }^{42}$ In a similar process to paper manufacturing, the nanocellulose was used for the creation of flexible and transparent papers. ${ }^{243}$ Besides the mechanical improvement of thermoset and thermoplastic polymers, ${ }^{244}$ the use of nanocellulose composites in the construction environment additionally benefited from the fire retardant properties of hybrid cellulose nanofibrils-clay minerals. ${ }^{245}$

Nanocellulose applications in food science focus on exploiting them as potential emulsion stabilizers, thickening agents, and functional ingredients in foods, such as dietary fiber to decrease the caloric content. ${ }^{246}$ The CNFs, CNCs, and BCs are considered as emulsion stabilizers for mayonnaise in combination with NFC/guar gum, ${ }^{247}$ as gelling and water binding additives in bread, ${ }^{248}$ and as dry protective media for probiotics. ${ }^{249}$ Whey protein gels can be tuned with potential gelling properties and their microstructure can be better controlled by adding CNCs in specific heat treatment conditions. The CNCs have decent protein matrix compatibility at comparatively lower concentrations. Furthermore, CNCs can be used as a vigorous dehydrating agent to capture the moisture in the protein matrix, it can endorse protein cross-linking at higher $\mathrm{CNCs}$ concentrations.250 However, only BC is 
regulated by the Food and Drug Administration (FDA) as a nanocellulose material that is "Generally Recognized As Safe (GRAS)". In vitro and in vivo toxicology analyses in physiologically relevant systems of ingested nanocellulose (in case, a CNF suspension) did not detect any harmful effects and it was suggested that consumed nanocellulose has a critical negligible toxic reaction at low concentrations ${ }^{251}$. Therefore, BC is also recognized as a safe food additive by the European Union (EU). Nanocellulose in food packages has been intensively studied in the last decade: the CNC and CNF are effective to provide improved shelf-life. ${ }^{252}$ Nanocellulose composites and bio-based polymer is used as protective food package coatings or individual films for increasing the barrier properties.253 Thus, nanocellulose and its associated nanocomposites have a good perspective to progressively replace current plastics and cellulose-based materials in main industrial applications.

\section{Hemicelluloses and their associated nanomaterials}

Hemicelluloses are present in the plant cell wall to offer structural strength by crosslinking between cellulose with lignin and are considered the second most copious polymer on earth. 254 They are the second vital constituent of wood and make up to $20-35 \%$ of the dry wood weight. Hemicelluloses usually have a relatively low degree of polymerization and provide a broad range of polysaccharides for biotic purposes. ${ }^{255}$ The polymerization level of hemicellulose is lower because they are made of small molecules, compared with cellulose: the hemicellulose contains sugar molecules with a few chains of 500 to 3,000 units, whereas cellulose contains glucose with 7,000 to 15,000 molecules per polymer chain. Unlike cellulose, hemicellulose contains a diversity of glycosidic bonds in a single molecule, which makes them amorphous in nature and soluble in water. The specific molecular composition varies among the different plant types and the parts from which they are extracted. The main categories of hemicellulose structures can be classified into xylan, xyloglucan, mannan, and mixed $\beta$-glucan linkages, depending on the chemical structure. The xylose is the main monomer next to mannose, galactose, and glucose, whereas arabinose and rhamnose are less frequent. After hydrolysis, the hemicellulose can be effortlessly converted into biofuel or biochemicals such as furfural, levulinic acid, or xylitol. 256

\subsection{Hemicellulose types and classifications}


Plant-derived hemicelluloses have many different sugar units, such as xylan, mannans, arabinans, and galatians, all potential biomaterial sources, according to the plant type (Figure 17). Hemicelluloses are heterogeneous polymers with a random amorphous edifice. The main hemicelluloses are arabinoglucuronoxylan and galactoglucomannan in softwoods, and glucuronoxylan in hardwoods, where acetyl groups are usually embedded in galactoglucomannan and glucuronoxylan. Although the properties imparted by hemicelluloses to the cell walls are not clear, they act as an intermediate structure forming cross-links with cellulose via hydrogen bonds that may influence the microfibril properties 257, and also with lignin to offer strength.258, 259 Xylans are present in high quantities in hardwood hemicellulose, but they are also present in cereals and annual plants. Moreover, hemicellulose composition and structure depend on the botanical source from which they are obtained. ${ }^{154}$ Highly pure hemicelluloses can be isolated from various plant sources, for instance, bamboo. Their solubility is the main factor that influences their extraction from the cell walls with neutral and alkaline solutions. ${ }^{260}$ The alkali-based isolation of hemicellulose by deacetylation is gaining scientific interest. Recently, an approach to extract hemicelluloses from bamboo using alkali treatment was described in which the powder was retrieved with a mixture of toluene and ethanol.261 The obtained sample after dewaxing was preserved with sodium chlorite $\left(\mathrm{NaClO}_{2}\right)$ to yield hemicellulose. The resulting hemicellulose was retrieved with distilled hot water and $2 \%$ sodium hydroxide. Finally, two fractions of hemicelluloses (named HA and HB) were obtained with an overall yield of $26.2 \%$. In hemicellulose, the main sugar was xylose, whereas HA and HB contained arabinose and galactose, respectively, as end-products. Hemicellulose polymers with high purity can be obtained also by combining ultra-filtration and chromatography. ${ }^{154}$ 


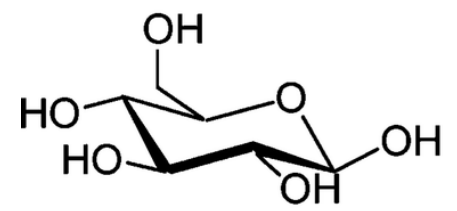

D-glucopyranose

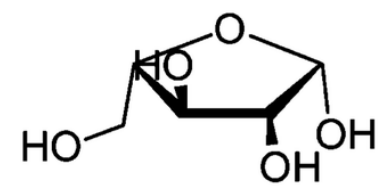

L-arabinofuranose

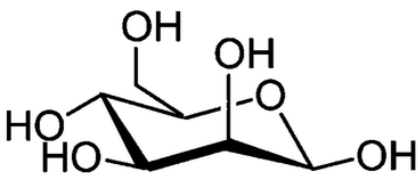

D-mannopyranose

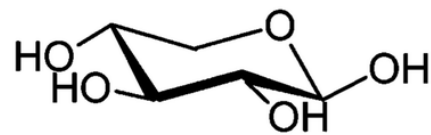

D-xylopyranose

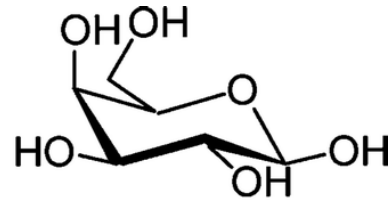

D-galactopyranose<smiles>O=C[C@H](O)[C@@H](O)[C@H](O)[C@H](O)C(=O)O</smiles>

D-glucuronic acid

Figure 17. Plant-derived hemicelluloses are composed of many different sugar units (e.g. xylan, mannans, arabinans, and galatians) that can form different hemicellulose types 262 , (OThe Royal Society of Chemistry (2011).

Hemicellulose-based biomaterials are non-toxic, biocompatible, bioactive, and mostly function as good oxygen barriers. The hemicelluloses can be converted into several biopolymers (e.g., polyhydroxyalkanoates and polylactate), or further hydrolyzed into individual hexose and pentose sugar units as a basic chemical for ethanol fuel and other biobased products. ${ }^{263}$ In industries, hemicelluloses are used to regulate the aqueous phase rheology. Thus, they can be employed as food thickeners, additives, and adsorbents. ${ }^{264}$ Moreover, hemicelluloses are extensively studied for possible medical applications, ${ }^{154}$ such as ulcer protective, ${ }^{265}$ antitussives, ${ }^{266}$ immunostimulatory agents, 267 and antitumor compounds. ${ }^{268}$

\subsection{Fabrication of hemicellulose nanoparticles}

Although bulk and micro-hemicelluloses can be used for various industrial applications, smaller sized hemicelluloses are needed to reduce their toxicity, increase their interaction with cells and their bioactivity for biomedical, pharmaceutical and environmental applications. Different methods have been assessed to fabricate nanosized hemicellulose particles, ${ }^{269}$ involving the use of metallic nanoparticles (e.g. $\left.\mathrm{Au}, \mathrm{Ag}, \mathrm{Pt}, \mathrm{Pd}\right),{ }^{270}$ metal oxide nanoparticles $\left(\mathrm{Fe}_{2} \mathrm{O}_{3}, \mathrm{TiO}_{2}, \mathrm{ZnO}\right),{ }^{271}$ carbon nanoparticles (carbon nanotubes and fullerenes), ${ }^{272}$ and nanocellulose-metal nanocomposites. ${ }^{273}$ For example, xylan-based nanoparticles (120 - $1800 \mathrm{~nm}$ in size) have been fabricated from corn cobs by neutralizing an 
alkaline solution with an acid..74 The xylan-based nanoparticles are extremely valuable for pharmaceutical applications, especially to produce carriers of drugs to target the colon in the form of nanosized particles with a coated film. The size of the obtained nanoparticles can be changed through many factors among the concentration ratio of hemicellulose and counteracting agent, the presence of additives, $\mathrm{pH}$, and the selection of enzymes for polymerization..$^{275}$ The smaller xylan nanoparticles ( 30 to $90 \mathrm{~nm}$ in size) have been fabricated using a simple method to isolate xylan from wheat straw powder. ${ }^{276}$ This approach has several advantages due to the reaction under well-controlled conditions, lower cost, and elevated purity of the resulting nanoparticles. Other methods for the fabrication of nanosized hemicelluloses have been described, such as the dissolution of xyloglucans in dimethyl sulfoxide, acetone, and emulsions. Supercritical antisolvent (SAS) micronization is a recent technology to obtain spherical micro- and nanoparticles from hemicellulose solutions. These nanomaterials possess interesting features, particularly the dynamic compound formulation, controlled release of drug agents, and the possibility of separation by chromatography 275.

The extraction of hemicelluloses from plant sources is extensively applied as a primary step in the preparation of other significant nanoparticles. Using hemicellulose from bamboo as an additive and glucose as a reducing agent, the nanosized silver particles were synthesized 277 , by the addition of hemicellulose at high concentrations resulted in 5 to 20 $\mathrm{nm}$-sized silver particles. Likewise, hemicelluloses are useful as a tumbling agent in nanosized metal (e.g. Pt, Au, and Pd) particle synthesis as shown in Figure 18, where the use of xylan is responsible for the formation of irregularly shaped, 10-80 nm-sized metal nanoparticles. ${ }^{278}$ Different hemicelluloses, in particular xylans extracted from Dendrocalamus membranaceus, can be used to fabricate palladium nanoparticles with sizes of 8-18 nm with agglomerated spherical morphology, which are successfully applied as reusable catalysts for efficient carbon-carbon coupling. ${ }^{279}$ The hemicellulose hydrogels with in situ magnetic $\mathrm{Fe}_{2} \mathrm{O}_{3}$ NPs were produced through the acetyl-galactoglucomannan cross-linking of covalent bonds. ${ }^{280}$ These nanosized iron oxide particles could be used for controlling the hydrogel swelling behavior, thermal stability, magnetization, and macrostructure. Moreover, the hydrogel displayed a controlled release and adsorption properties towards bovine serum 
albumin. Therefore, these magnetic hemicellulose hydrogels might be exploited for magnetic bioseparation, controlled delivery of drugs, and tissue engineering applications.

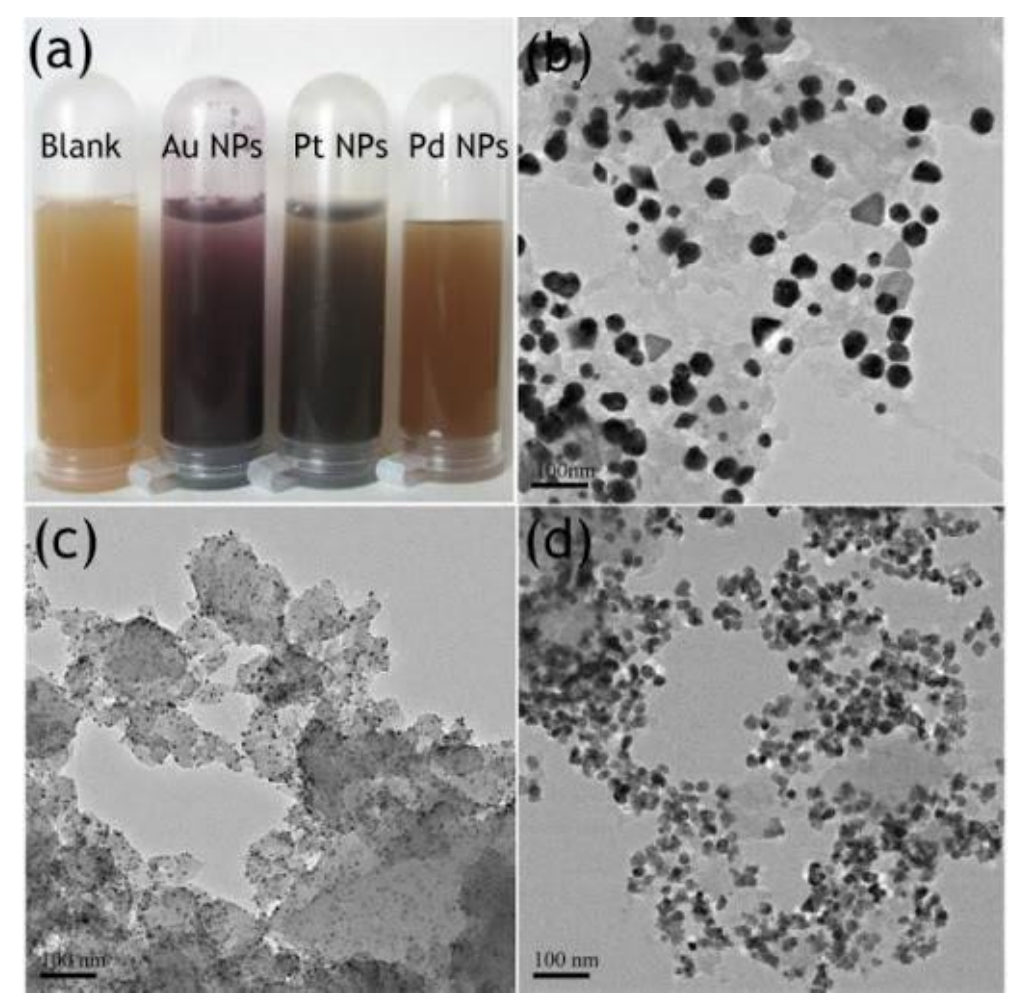

Figure 18. Hemicellulose-mediated synthesis of metal nanoparticles, (a) Optical observation of the nanoparticles, (b-d) TEM images of $\mathrm{Au}, \mathrm{Pt}$, and Pd NPs, respectively 278, OElsevier (2017).

Recently, several processing routes have been developed for the formulation of hemicellulose-based nanocomposites to overcome the limitations of nanosized hemicellulose and its individual nanoparticles. In a simple and effective approach, high-quality nanosized hemicellulose composite films ( 10 to $70 \mathrm{~nm}$ in diameter) were produced by the combinations of CNFs with xylan films using plasticizers. ${ }^{281} \mathrm{~A}$ freeze-thaw technique was used to fabricate innovative hybrid hydrogels from bamboo-retrieved hemicellulose, polyvinyl alcohol, and nanosized chitin whiskers for tissue culture applications. ${ }^{282}$ An intercalated structure of quaternized hemicellulose-based nanocomposites with cationic chitosan biopolymers and montmorillonite was transformed into a film with excellent properties of thermally stability, low permeability to oxygen and water vapor, and with enhanced mechanical strength due to the effective hydrogen bonding and electrostatic interaction. ${ }^{283}$ Similarly, the individual nanoparticles of graphene oxide can be cross-linked within nanocomposites of hemicellulose 
hydrogels in order to improve the toughness and elastic property of the individual nanoparticles. ${ }^{284}$ The fully bio-based composite films were obtained by the addition of hemicellulose xylan and glucomannan to nanosized films of cellulose fibers with enhancement in elasticity, strength, and UV blocking properties. ${ }^{285}$

The presence of distinct monosaccharides, secondary alcohols, and other components in hemicellulose makes them act favorably as a reducing agent. ${ }^{286,287}$ Therefore, hemicelluloses are used for the fabrication of nanoparticles, including nanosized metal nanoparticles (e.g. $\mathrm{Au}, \mathrm{Pt}, \mathrm{Ag}, \mathrm{Pd}$ ), ${ }^{270}$ metal oxides (e.g. $\mathrm{TiO}_{2}$ and $\mathrm{ZnO}$ ) ${ }^{271}$, carbon-based particles (carbon nanotubes and fullerenes), 272 and nanocomposites (nanocellulose-metal nanoparticles). ${ }^{273}$ In the presence of hemicellulose, the palladium-xylan nanocomposites with nitrogen and oxygen ligands showed improved catalytic activity with $100 \%$ yield, compared with palladium catalysts, and retain their activity even after recycling for five times ${ }^{288}$. The xylan-silver nanocomposite films were prepared via a solution casting method in which hemicellulose from oil palm empty fruit bunch was blended with montmorillonite and carboxymethyl cellulose, which might be interesting for novel green food packaging applications. ${ }^{289}$ The composite films display enhanced functional barrier activity, exclusive tensile strength, tensile modulus, and permeability to water vapor. Figure 19 illustrates the possible mechanism underlying the formation of xylan-silver nanocomposites that show a strong integration between different components in the molecular structure. Table 5 summarizes the different nanoparticles and nanocomposites that are fabricated using hemicelluloses extracted from plant sources. 


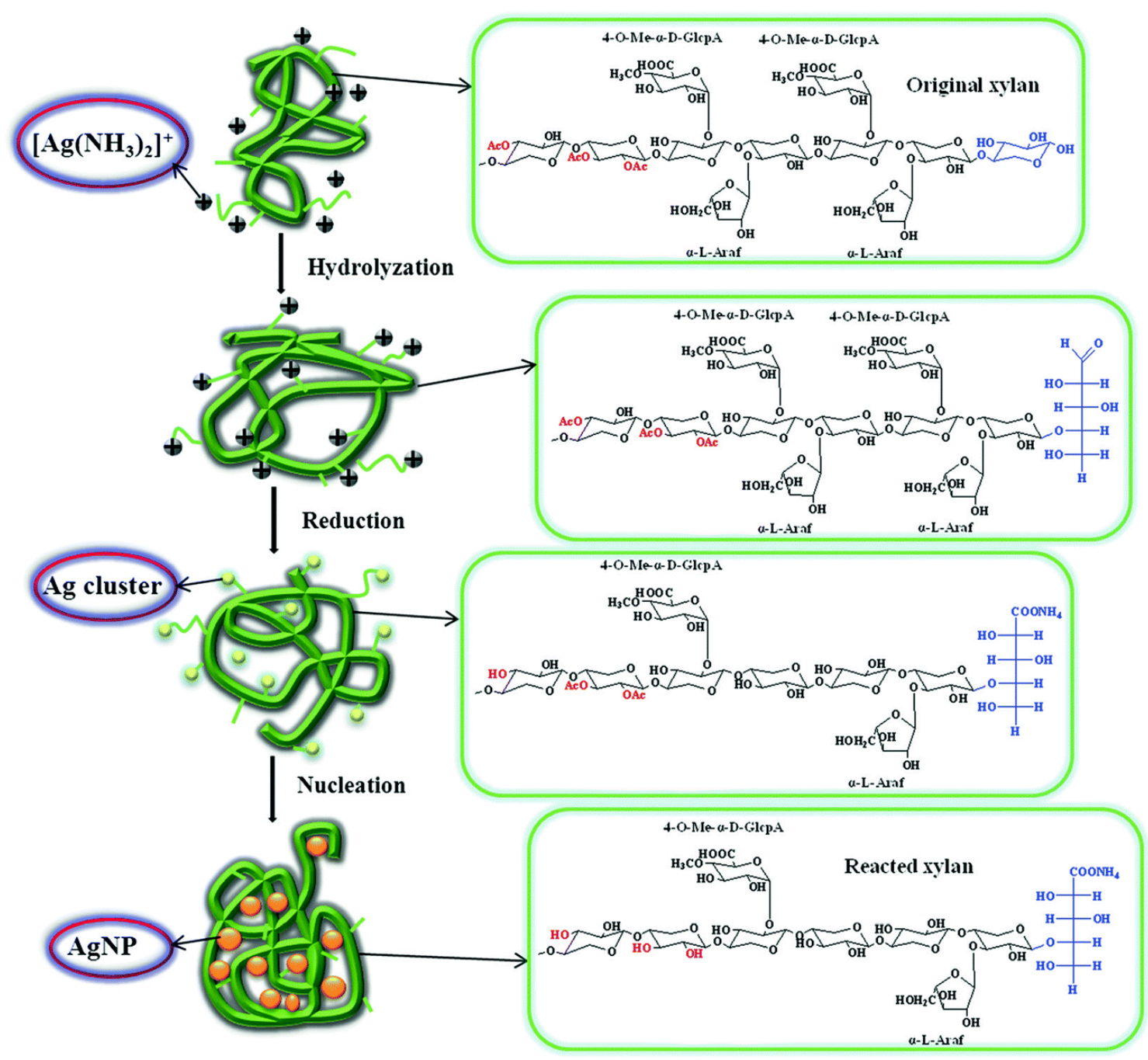

Figure 19. Mechanism of xylan-silver nanocomposites formation, including (i) hydroxylation of the hemicelluloses; (ii) reduction of silver ions in silver metal (clusters); (iii) nucleation and crystal growth of the Ag atoms (clusters) to form Ag nanoparticles ${ }^{289}$, (CNC State University (2019).

Table 5. Production of different nanoparticles using plant-extracted hemicellulose

\begin{tabular}{|l|l|l|l|l|}
\hline \multicolumn{1}{|c|}{ Products } & Plant source & \multicolumn{1}{|c|}{ Method } & Morphology & \multicolumn{1}{|c|}{ Reference } \\
\hline Silver & Bamboo & Microwave- & Shape: & 290 \\
& & assisted method, & spherical & \\
& & glucose as reducer & Size: 8.3-14.8 & \\
& & and hemicellulose & $\mathrm{nm}$ & \\
& & as a stabilizer & & \\
\hline
\end{tabular}




\begin{tabular}{|c|c|c|c|c|}
\hline $\begin{array}{l}\text { Palladium } \\
\text { nanoparticles }\end{array}$ & $\begin{array}{l}\text { Dendrocalamus } \\
\text { membranaceus } \\
\text { Munro }\end{array}$ & $\begin{array}{l}\text { Deposition- } \\
\text { precipitation } \\
\text { method using } \\
\text { xylan-type } \\
\text { hemicellulose }\end{array}$ & $\begin{array}{l}\text { Shape: } \\
\text { spherical } \\
\text { Size: } 8-18 \mathrm{~nm}\end{array}$ & 279 \\
\hline Hydrogels & Picea abies & $\begin{array}{l}\text { Cross-linking of } \\
\text { hemicelluloses, } \\
\text { such as alkaline- } \\
\text { based } \\
\text { polysaccharide } \\
\text { deprotonation of } \\
\text { hydroxyls and } \\
\text { epichlorohydrin } \\
\text { ring formation }\end{array}$ & $\begin{array}{l}\text { Porous } \\
\text { structure }\end{array}$ & 280 \\
\hline $\begin{array}{l}\text { Xylan } \\
\text { nanoparticles }\end{array}$ & Corn cobs & $\begin{array}{l}\text { Neutral extraction } \\
\text { and precipitation } \\
\text { after de- } \\
\text { lignification }\end{array}$ & $\begin{array}{l}\text { Shape: } \\
\text { spherical } \\
\text { Size: } 100-900 \\
\text { nm }\end{array}$ & 274 \\
\hline $\begin{array}{l}\text { Hemicellulose } \\
\text { nanocomposites }\end{array}$ & $\begin{array}{l}\text { Sinocalamus } \\
\text { affinis }\end{array}$ & $\begin{array}{l}\text { Nanoparticle film } \\
\text { by sonication and } \\
\text { rotary vacuum } \\
\text { evaporator }\end{array}$ & $\begin{array}{l}\text { Shape: } \\
\text { nanoplates } \\
\text { Size: } 83-113 \\
\text { nm }\end{array}$ & 283 \\
\hline $\begin{array}{l}\text { Xylan } \\
\text { nanoparticles }\end{array}$ & Beechwood & $\begin{array}{l}\text { Xylan treated with } \\
\text { ibuprofen ester via } \\
\text { perpropionylation, } \\
\text { sulfation and } \\
\text { dialysis }\end{array}$ & $\begin{array}{l}\text { Shape: } \\
\text { spherical } \\
\text { Size: } 162-142 \\
\text { nm }\end{array}$ & 291 \\
\hline $\begin{array}{l}\text { Cellulose } \\
\text { nanofiber-xylan } \\
\text { nanocomposite } \\
\text { film }\end{array}$ & $\begin{array}{l}\text { Dendrocalamus } \\
\text { membranaceous } \\
\text { Mundro }\end{array}$ & $\begin{array}{l}\text { Bleached sisal pulp } \\
\text { with } \\
\text { homogenizing } \\
\text { process }\end{array}$ & $\begin{array}{l}\text { Thickness: 52- } \\
62 \pm 2-3 \mu \mathrm{m}\end{array}$ & 292 \\
\hline
\end{tabular}




\begin{tabular}{|c|c|c|c|c|}
\hline $\begin{array}{l}\text { Graphene } \\
\text { oxide- } \\
\text { polyacrylamide- } \\
\text { aluminum ion- } \\
\text { carboxymethyl } \\
\text { hemicellulose } \\
\text { nanocomposites }\end{array}$ & Wheat straw & $\begin{array}{l}\text { Microwave- } \\
\text { assisted process } \\
\text { with sodium } \\
\text { monochloroacetate }\end{array}$ & $\begin{array}{l}\text { Porous, tough } \\
\text { and elastic }\end{array}$ & 293,294 \\
\hline $\begin{array}{l}\text { Gold } \\
\text { nanoparticles }\end{array}$ & $\begin{array}{l}\text { Japanese } \\
\text { Hinoki wood }\end{array}$ & $\begin{array}{l}\text { Sonicated wood } \\
\text { flour with } \\
\text { hemicellulose as } \\
\text { reducing agent } \\
\text { and gold precursor }\end{array}$ & $\begin{array}{l}\text { Shape: } \\
\text { dispersed } \\
\text { spherical } \\
\text { Size: } 2.3 \pm 0.7 \\
\mathrm{~nm}\end{array}$ & 295 \\
\hline $\begin{array}{l}\text { Xylan stearate } \\
\text { nanoparticles }\end{array}$ & $\begin{array}{l}\text { Local (China) } \\
\text { viscose fiber } \\
\text { mills }\end{array}$ & $\begin{array}{l}\text { Spray drying of } \\
\text { xylan with } \\
\text { dimethyl sulfoxide }\end{array}$ & $\begin{array}{l}\text { Shape: } \\
\text { spherical } \\
\text { unimodal } \\
\text { Size: 194-215 } \\
\mathrm{nm}\end{array}$ & 296 \\
\hline $\begin{array}{l}\text { Silver } \\
\text { nanoparticles }\end{array}$ & $\begin{array}{l}\text { Sugarcane } \\
\text { bagasse }\end{array}$ & $\begin{array}{l}\text { Soxhlet extraction } \\
\text { to obtain sugar, } \\
\text { especially } \\
\text { hemicellulose, as } \\
\text { reducing agent, } \\
\text { with silver } \\
\text { precursor }\end{array}$ & $\begin{array}{l}\text { Shape: semi- } \\
\text { spherical } \\
\text { Size: } 8-30 \mathrm{~nm}\end{array}$ & 297 \\
\hline
\end{tabular}

\subsection{Applications of hemicellulose nanomaterials}

Due to their enhanced bioavailability, biocompatibility, bioactivity, and lower toxicity towards healthy cells and the environment, nanosized hemicellulose materials and particles are currently extensively investigated for a broad range of biomedical, food or food packaging, energy and environmental applications, shown as an overview in Table 6. 
Table 6. Applications of nano-hemicellulose nanomaterials

\begin{tabular}{|c|c|c|}
\hline Field of application & Description & References \\
\hline Drug delivery & $\begin{array}{l}\text { Drug carrier for oral drug delivery to the intestine } \\
\text { and controlled drug release of theophylline and } \\
\text { acetylsalicylic acid }\end{array}$ & 298,299 \\
\hline Tissue engineering & $\begin{array}{l}\text { Wound healing of muscle tissue, and bone tissue } \\
\text { engineering }\end{array}$ & 300 \\
\hline Biomedical scaffolds & $\begin{array}{l}\text { Fabrication of scaffolds to support bone and tissue } \\
\text { growth }\end{array}$ & 301 \\
\hline Bioimaging & $\begin{array}{l}\text { Nitrogen-doped carbon quantum dots with xylan as } \\
\text { fluorescent probes to detect tetracycline }\end{array}$ & 302 \\
\hline Water treatment & $\begin{array}{l}\text { Hemicellulose-based hydrogels are an ideal } \\
\text { adsorbent for heavy metal removal, such as lead } \\
\text { from contaminated water }\end{array}$ & 303 \\
\hline Batteries & $\begin{array}{l}\text { Anode material and hard carbon performance in } \\
\text { lithium-ion and sodium-ion batteries }\end{array}$ & 304,305 \\
\hline Supercapacitors & $\begin{array}{l}\text { Hemicellulose-derived aqueous hydrolysis products } \\
\text { as electrode materials for supercapacitors }\end{array}$ & 306,307 \\
\hline Cosmetics & Antiaging ingredient for cosmetic formulations & 308 \\
\hline Foods & $\begin{array}{l}\text { Coating material with Arabic gum for food } \\
\text { microencapsulation }\end{array}$ & 309 \\
\hline Packing & $\begin{array}{l}\text { Acetylated and high-strength hemicellulose } \\
\text { nanocomposite films for active food packages }\end{array}$ & 283,310 \\
\hline Biofuel & Production of bioethanol and alcohol-based fuel & 311 \\
\hline
\end{tabular}

\subsubsection{Biomedical applications}

Hemicelluloses can particularly offer specific biological functions, such as antioxidative, anti-tumor, and immunomodulating activity. ${ }^{312}$ Therefore, the combination of hemicelluloses into cellulose nanofiber scaffold networks may improve their performance in biomedical applications. When added in combination with a nanocellulose hydrogel, the hemicelluloses do not only serve as a crosslinker to tune the structural and mechanical 
properties, but they also positively stimulate the cellular growth during wound healing applications. ${ }^{313}$ The amount and type of the incorporated hemicellulose and the hydrogel swelling time affect the pore structure, and the mechanical strength of the composite hydrogel scaffolds ${ }^{300}$. The hemicellulose hydrogels were created from a hydrophilic network of xylan-rich hemicellulose, epichlorohydrin, and aniline pentamer terminated by a carboxyl group. The hydrogel features of a very stable macro-porous structure, tunable conductivity, and improved swelling behavior suggest their high potential as drug carriers and delivery media in biomedical applications. ${ }^{313}$

The nanoparticles and nanocomposites of hemicellulose are useful for biomedical applications, such as targeted delivery of drugs, antimicrobial agents, biosensors, and disease treatment, as illustrated in Figure 20. The fabrication of nanosized hemicellulose particles from microcrystalline cellulose, corn starch, and hemp fiber is enhanced in the presence of trifluoroacetic acid: ${ }^{315}$ these and targeted encapsulation and release of curcumin from those nanoparticles can be controlled via a pH-dependent mechanism, and show about $65 \%$ of delivery capacity. The xylan-based nanoparticles can generally act as a pro-drug to release ibuprofen, a drug used to reduce fever or pain, at the target site. ${ }^{291}$ Several laboratories are currently working on production methods to fine-tune the properties of hemicellulose-based nanocomposites, depending on the desired applications, particularly for the pharmaceutical and biomedical fields. The hemicellulose assisted in the fabrication of silver nanoparticles (25-30 nm in size) using liquor from Eucalyptus wood after hydrolyzation, in which high quantities of polyphenols, hemicellulose, and their derivatives are present as metabolites. ${ }^{314}$ The antimicrobial activity of the resulting nanosized particles (i.e. Inhibition of the bacterium Pseudomonas aeruginosa and the fungi Penicillium chrysogenum and Cladosporium oxysporum) showed high potential as effective an antimicrobial agent. The core-shell structure of quaternized xylan-iron oxide nanoparticle with surface modifications via folic acid and polylysine might be employed in magnetism-mediated target delivery of drugs, especially for cancer treatment. ${ }^{315}$ Similarly, the silica nanoparticles with the presence of high hemicellulose content can be fabricated from rice husks for various biomedical applications. $^{316}$ 


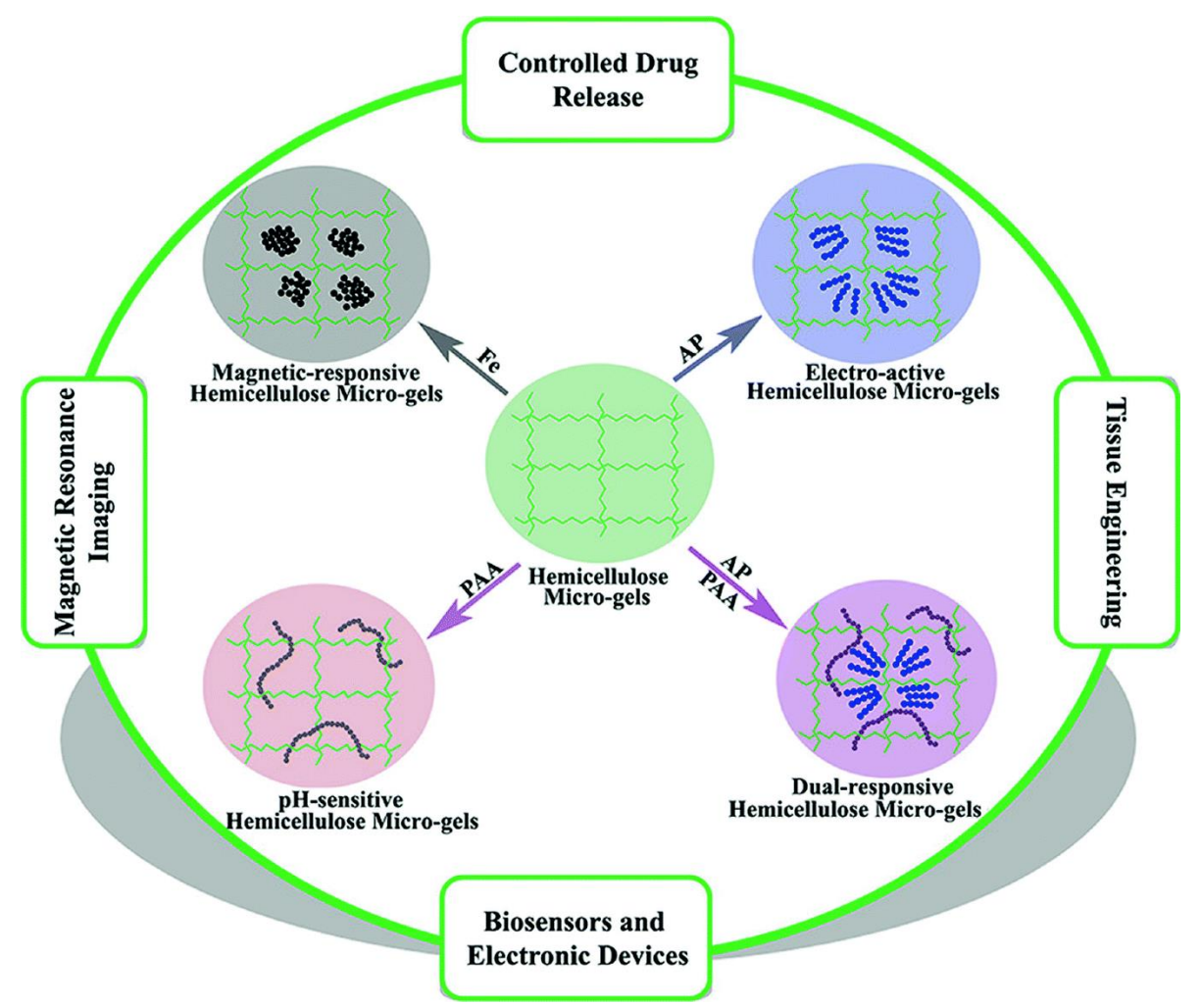

Figure 20. Hemicellulose microgel types and their potential biomedical applications, ${ }^{317}$ (C)American Chemical Society (2015).

\subsubsection{Food packaging application}

Hemicellulose-based nanoparticles and nanomaterials are commonly used as a bioplastic packaging material due to their favorable barrier resistant properties combined with high strength and stiffness and resistance against abrasion. Specifically, hemicellulosebased nanosized films are employed as food packages to replace conventional petroleumbased composite films (Figure 21). ${ }^{318}$ A novel method was developed to fabricate hemicellulose nanocomposite films with high strength for food packaging applications.283 The nanocomposites fabricated with xylan-rich hemicellulose nanofibers yield highly durable food packages due to their improved mechanical properties as a single film, ${ }^{292}$ or coating material. ${ }^{319}$ In particular, the xyloglucan type of hemicellulose-based polymers and nanocomposites act as an extremely good oxygen barrier, ${ }^{320}$ either derived from softwood hemicellulose, 321 or plasticized hardwood xylans. ${ }^{322}$ The combination of modified hemicellulose nanocomposites with nanosized clay platelets in organic-inorganic nanocomposite films further enhanced the barrier performance. ${ }^{323}$ Indeed, food packages 
produced using these novel composites can control the oxygen interaction with food and simultaneously regulate pathogen growth.
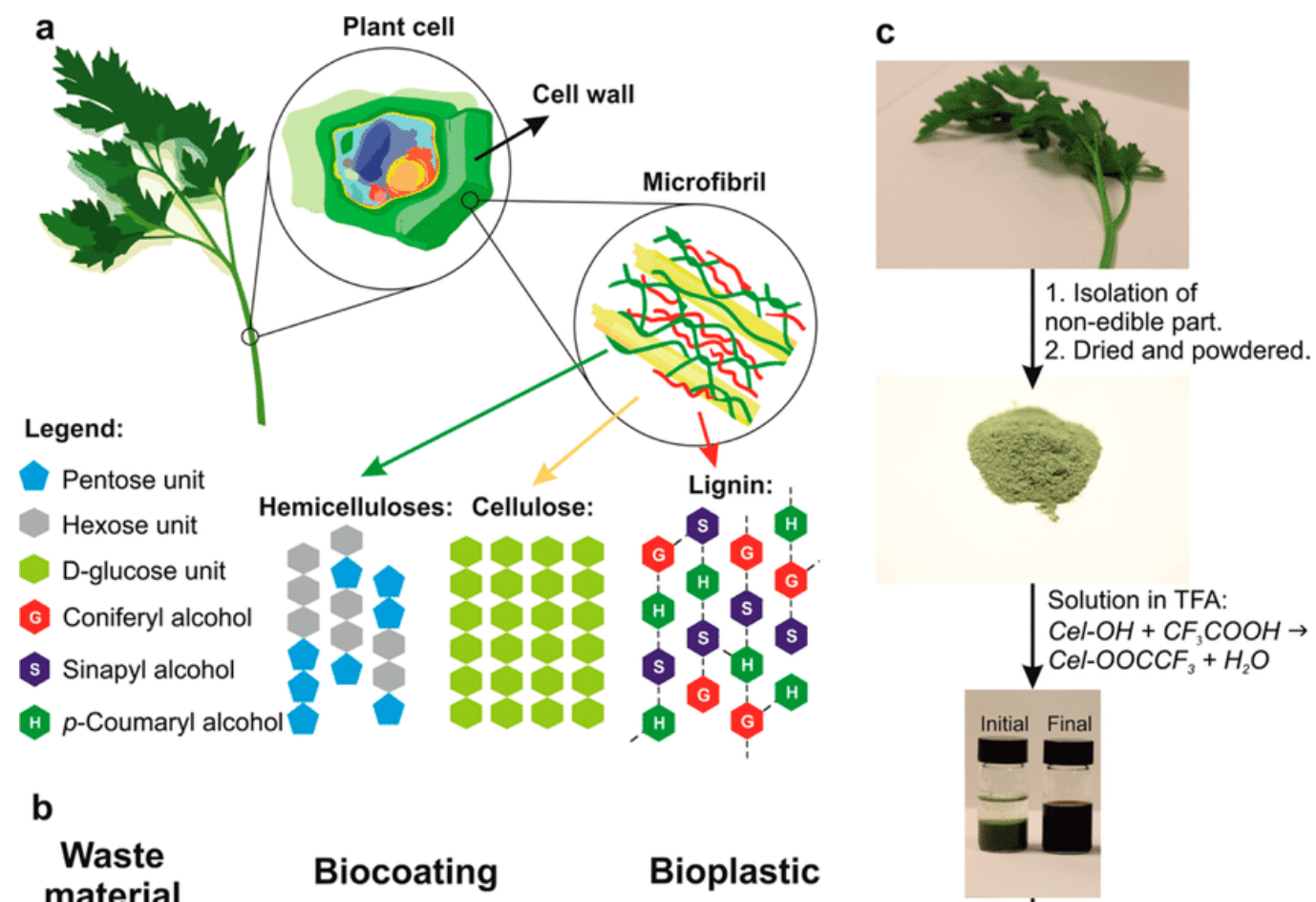

Bioplastic
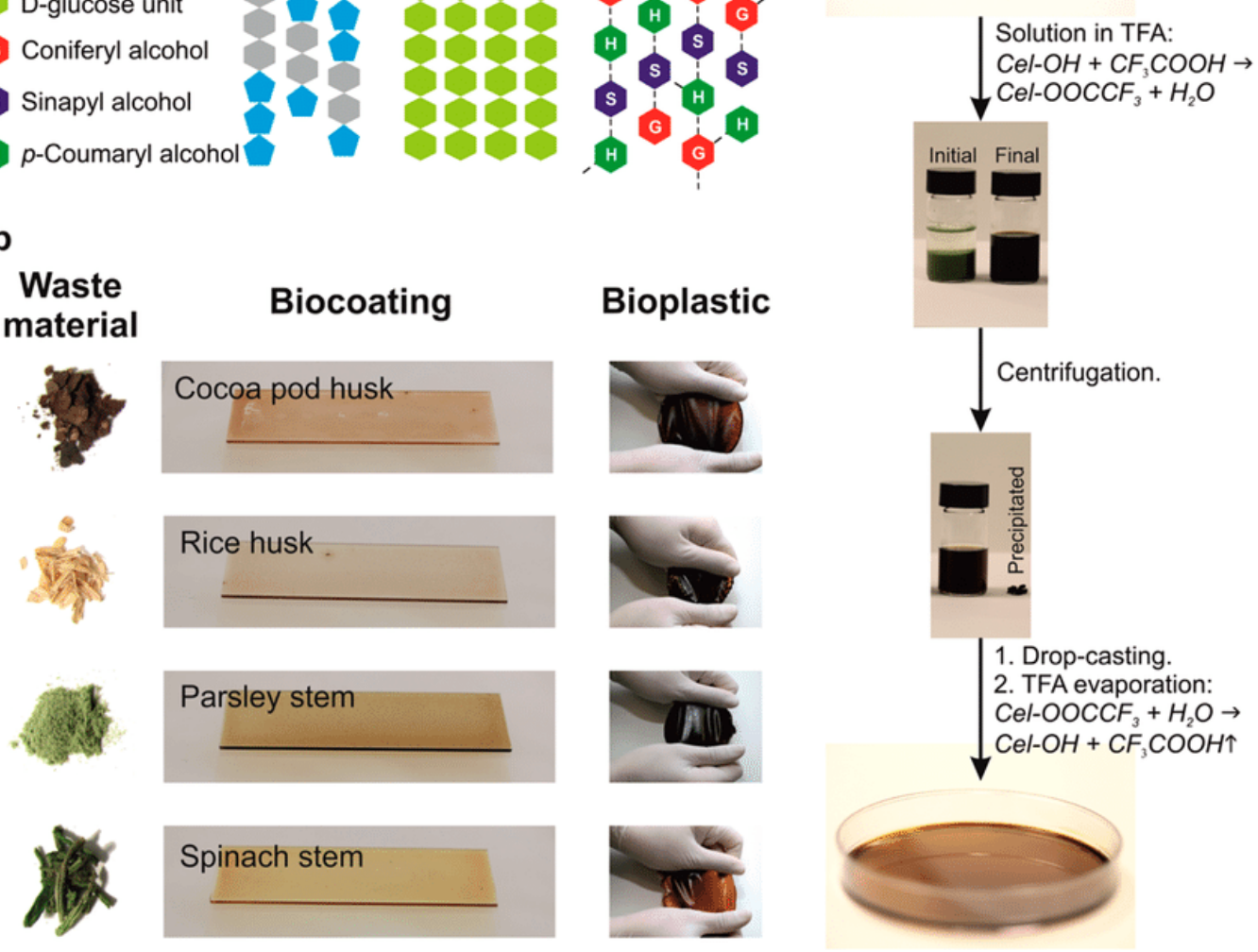

Drop-casting

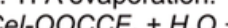
$\mathrm{Cel}-\mathrm{OH}+\mathrm{CF}_{3} \mathrm{COOH} \uparrow$
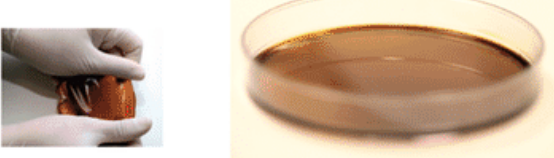

Figure 21. Valorization route for residual products from edible plants. (a) Schematic description of hemicellulose, cellulose, and lignin and their distribution at different scales. (b) Transformation of plant residues into biocoatings and bioplastic products. (c) Bioplastic production from the plant residues to the final films: pulverized vegetable residues are dissolved in trifluoroacetic acid (TFA), and after aging, the solution is cast into a Petri dish. Centrifugation can be used to eliminate the undissolved parts,324 @American Chemical Society (2014). 


\subsubsection{Other novel applications}

The hemicellulose-based nanoparticles and nanocomposites are also used for other applications, including membranes and filters for environmental cleaning. The biosorbents of nanoparticles fabricated from agricultural biomass with high hemicellulose content was used to eliminate heavy metals from industrial and municipal wastewater systems. ${ }^{325}$ Similarly, biocomposite fibers from Eleocharis dulcis with high hemicellulose content and incorporated with nanosized iron particles can be employed for wastewater treatment by the textile industry. ${ }^{326}$ Therefore, research on biosynthesized hemicellulose-based nanoparticles and nanocomposites for various applications should be considered a priority. The hemicellulose provides benefits as a green material able to add both functionality and mediate the long-term stabilization process of the resultant nanomaterials.

\section{Lignin and associated nanomaterials}

Lignin is a heterogeneous biopolymer with a complex structure of highly irregular crosslinked polyphenols without having a well-defined primary unit. ${ }^{327}$ Lignin makes up about $30 \%$ of non-fossilized organic carbon and has a different chemical structure depending on its origin from softwood, hardwood, or grass. ${ }^{328}$ The resulting lignin materials possess exclusive properties, including resistance to the biological decay, the absorbance of ultraviolet light, and antioxidative activity. ${ }^{329}$ Every year, about $20 \times 10^{9}$ tons of lignin are produced by photosynthesis and are typically found in the central lamella between the wood cell and the subordinate cell wall. Lignin is an intermittently polyphenolic branched polyether with prime monolignols, p-coumaryl and sinaply alcohol, that is associated via the aliphatic ether, aromatic, and nonaromatic C-C bonds. ${ }^{330}$ Lignin is composed of model monomers, such as syringyl, $p$-hydroxyphenyl and guaiacyl, and its composition varies in function of the plant source due to variations in the concentration of these monomers. For instance, softwoods (e.g. Pine trees) contain more guaiacyl and hydroxyphenyl, whereas hardwoods, present guaiacyl and syringyl. The presence of guaiacyl and syringyl in hardwoods reduces the concentration of branch formation resulting in a higher processability. 331 As described for cellulose and hemicellulose, lignin has been used to fabricate nanoparticles and nanomaterials because it can reduce, stabilize, and molecularly induce nanosized particle formation starting from the nucleation stage. ${ }^{332}$ 


\subsection{Lignin classification and extraction}

Lignins can be classified depending on the plant species from which they originate (softwood, hardwood, and grass lignin) and the processing methods (Kraft, soda, sulfite pulping, organosolv, steam-explosion, diluted acid, and enzymatically hydrolyzed lignin) ${ }^{333,}$ 334. The Kraft process is a chemical-based method to extract cellulose fibers from plant sources by pulping, and from fresh wood by degrading and dissolving lignin. Carbon-carbon bonds are formed with lignin in the final pulping phase via condensation in order to yield a strong lignin structure ${ }^{335}$. The soda process uses sodium hydroxide for the extraction of lignin from the agricultural waste of annual plants ${ }^{336}$. Anthraquinones are generally added to the soda to increase the rate of delignification and consequently make the lignin production economically viable. Soda lignin is similar to natural lignin without the sulfur functionality and can be used in various applications ${ }^{337}$. Sulfite pulping is a process in which the reaction between biomass and sulfur dioxide leads to the formation of sulfonic acid that can dissolve and separate lignin in aqueous solution. The obtained lignin contains functional groups, such as lignosulfonate and its associated acid and group of carboxylic acids with aliphatic or phenolic hydroxyl compounds. Due to its high sulfur content, lignin obtained by sulfite pulping is a potential pulp mill fuel and inorganic compound recovery agent 338 .

Organosolv defines various processes to delignify biomasses by adding an organic mixture with water to retrieve lignin from wood or biomass, especially hardwood and annual plants. The obtained lignin is sulfur-free with a molecular weight of $5 \mathrm{kDa}$, which is lower compared with other lignin forms ${ }^{339}$. Acetosolv, Alcell, and Milox are the three types of organosolv methods for pilot-scale production of lignin. They use an acid catalyst in acidic solvent conditions to extract lignin at a comparatively lower temperature than other processes without sulfur or chlorine-based chemicals. ${ }^{340}$ Lignin extraction by steam explosion and hydrothermal methods requires high temperature, compressed water, but short processing time in the presence of catalysts. This process is preferred for biofuel production, with decrements in molecular mass and better organic solubility, as observed for organosolv lignin ${ }^{341}$. Lignin can also be extracted from plant biomass and parts using diluted acids (e.g. phosphoric acid and peracetic acid), with high solubility and low production cost. These lignins display a porous structure that facilitates the access of enzymes for the production of xylose, biofuel precursors, and other fermentation sugars. ${ }^{342}$ Moreover, enzymes are used to 
hydrolyze plant biomasses to extract lignin. ${ }^{343}$ Lignocellulolytic enzymes, such as glycoside hydrolase, cellobiohydrolase, endo- $\beta-1,4$-glucanase, and ferulate 5 -hydrolase, are among the enzymes used to extract lignin from plant biomasses by enzymatic hydrolysis. ${ }^{344}$ Each of these lignin classes has its specific chemical structure and features that can be exploited for different applications. ${ }^{334,345}$ Figure 22 shows the dissolution method for the processing of wood chips and the fabrication of lignin in a final step of aggregation and precipitation.
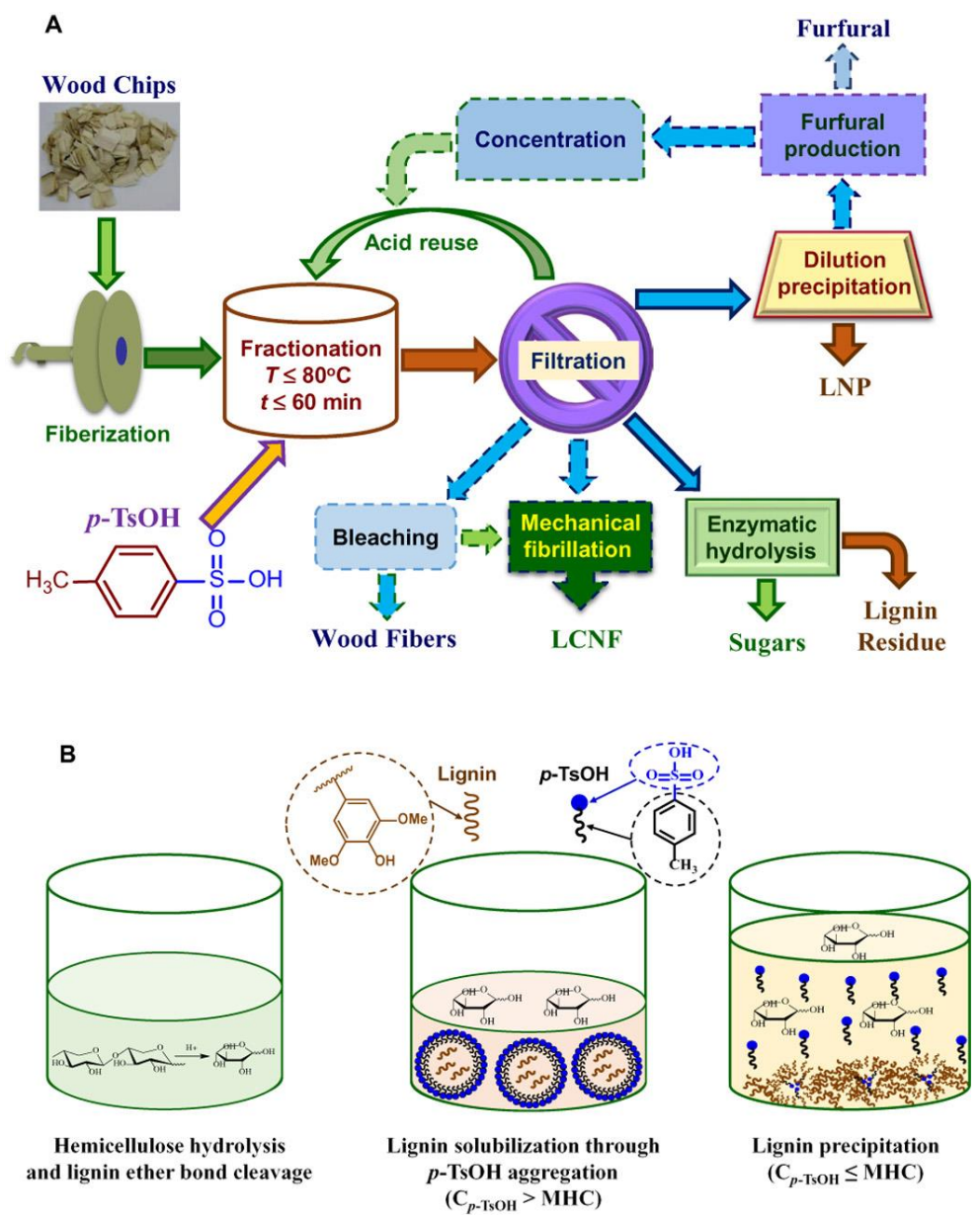

Figure 22. Processing method for wood fractionation recovery of lignin through a rapid and near-complete dissolution of wood chips at $\leq 80^{\circ} \mathrm{C}$ within a recyclable acid hydrotrope medium. (A) Schematic flow diagram for wood fractionation using $\mathrm{p}-\mathrm{TsOH}$ ( $p-$ toluenesulfonic acid) for production of fibers, lignocellulosic nanomaterials, sugars, and lignin nanoparticles. (B) Schematic for solubilization of carbohydrates and lignin and precipitation of lignin. ${ }^{221}$ @Science (2017). 


\subsection{Lignin-based nanomaterials}

Lignin is gaining significant scientific attention for the fabrication of nanoparticles and other nanostructures due to their large variation in properties and application fields. In particular, the valorization of lignin into novel nanomaterials as an alternative for the traditional incineration and energy production is economically attractive. For example, nanoparticles produced from hydroxymethylated lignin, due to their elevated hydroxyl group content, can serve as a phenolic auxiliary for the synthesis of formaldehyde-based phenol resins for bioremediation. ${ }^{346}$ Lignin nanoparticles are categorized in three major classes, depending on the fabrication method (Figure 23), including monomer polymerization, physical processing of insoluble polymers, and cross-linking of soluble polymers to form nanostructured materials 330, 347, 348. The Kraft and organosolv lignins can be used to fabricate colloidal lignin nanoparticles by flash precipitation. These nanoparticles (45 to $250 \mathrm{~nm}$ in size) have tunable surface properties and might be employed as a potential biodegradable carrier with minimal environmental footprint ${ }^{349}$. Likewise, pure nanosized lignin particles, iron complexes lignin nanoparticles, and iron oxide infused nanosized lignin particles are a potential carrier and transport particles for biomedical applications. The lignin nanoparticles can also be fabricated with smaller size range, spherical shape, compact polydispersity, and excellent stability at neutral $\mathrm{pH}$ : a study showed that lignin nanoparticles can be used for the targeted delivery of drugs and suggested that superparamagnetic iron oxide-lignin nanoparticles are useful in cancer theranostics, including magnetic resonance imaging and magnetic targeting. ${ }^{350}$ Similarly, metal-organic iron isopropoxide-based nanoparticles were fabricated by treating them with lignin as shown in Figure 24.351 The lignin nanoparticles were fabricated by a rapid and direct ultrasonication process starting from an alkaline pulping liquor, followed by precipitation under acid conditions. ${ }^{352}$ This method yielded spherical, nanosized lignin particles with negative surface charges and hierarchical nanosized structures in $5 \mathrm{~min}$. The generated nanoparticles were stable at $\mathrm{pH} 4$ 7 for 180 days and display good stabilizing and emulsifying properties in oil-in-water emulsions. 


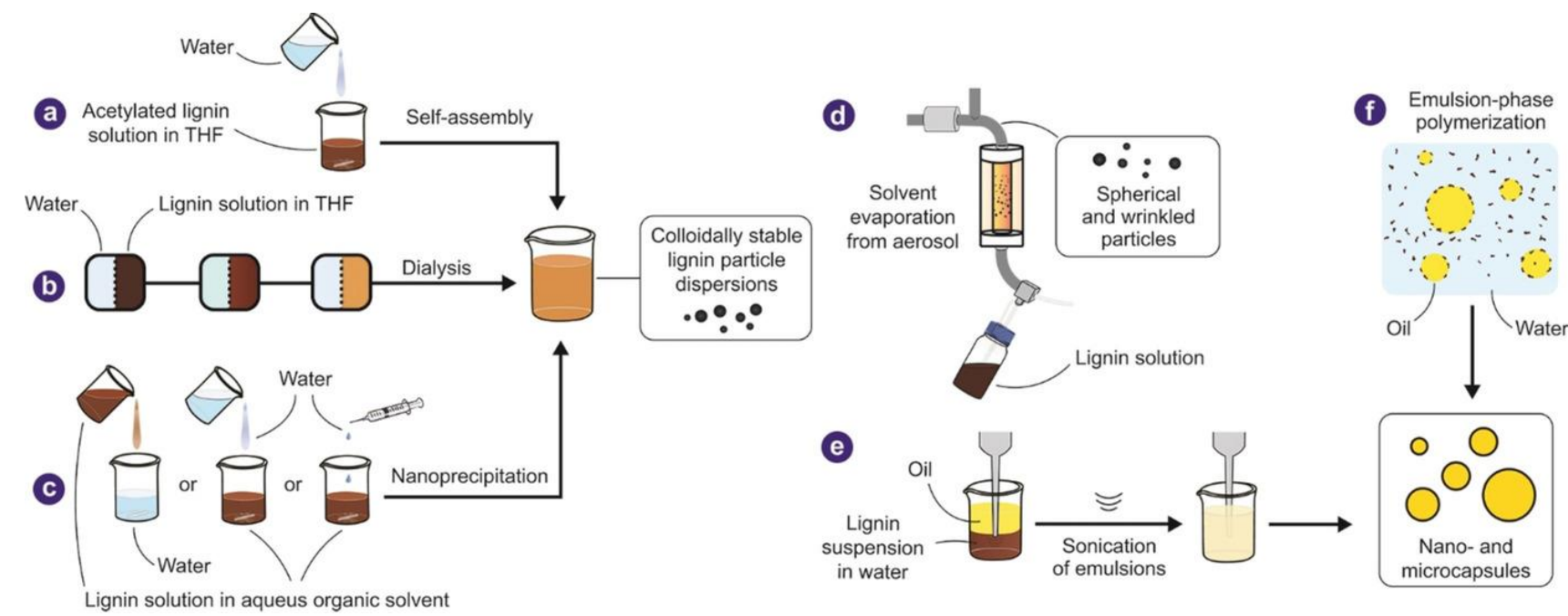

Figure 23. Methods for the production of nano- and micro-scale lignin materials. The lignin nanoparticle dispersions with good colloidal stability are prepared by (a) Addition of water to a solution of wheat acetylated lignin (AL) in tetrahydrofuran (THF), (b) Dialysis of nonacetylated softwood Kraft lignin (KL) in THF solution against deionized water, (c) Nanoprecipitation by adding water to a lignin solution, or vice versa, (d) Formation of microand nanoparticles in an aerosol flow reactor. (e) Formation of microcapsules by ultrasonication of KL containing a cross-linker. (f) Synthesis of nanoparticles, nano-capsules, and porous microparticles by emulsion-phase polymerization and cross-linking ${ }^{353}$, @Wiley-VCH Verlag GmbH \& Co. KGaA (2019). 
a)


b)

Sample 1: open network

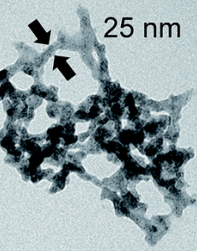

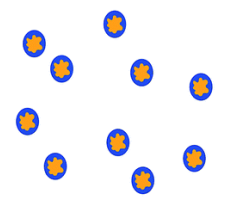

Sample 2: small solid particles
$3: 1\left(\mathrm{OH}_{\text {lignin }} / \mathrm{Fe}(\mathrm{OiPr})_{3}\right)$

$1^{\circ}$ rapid condensation $1^{\circ}$ controlled condensation

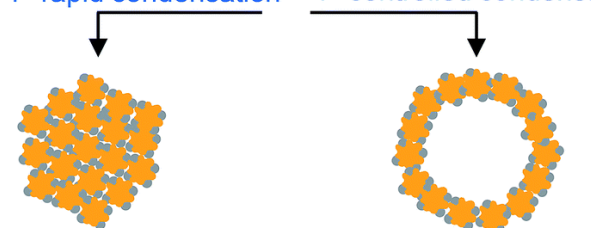

$2^{\circ}$ rapid hydrolysis $\downarrow$

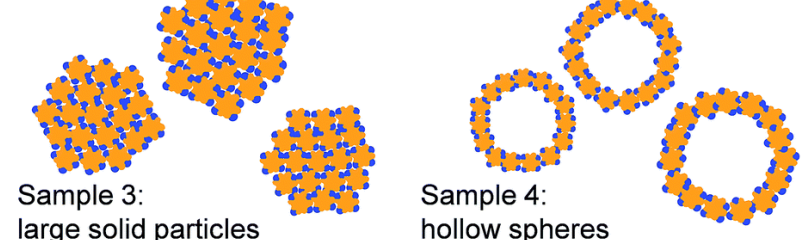

large solid particles

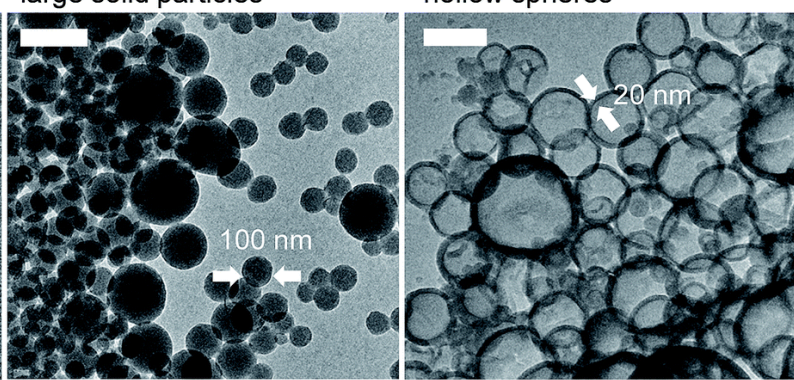

Figure 24. Synthesis of metal-organic nanoparticles from lignin treated by iron isopropoxide (Fe:lignin) and ability to obtain various morphologies by varying the reaction parameters, (a) schematic of different nanoparticle sizes and shapes. (b) TEM images of the obtained structures for Sample 1 (fishnet-type open network structures through rapid hydrolysis and fusing of $\mathrm{Fe}(\mathrm{OiPr})$ coated Fe: lignin nanoparticles), Sample 2 (small solid particles through controlled hydrolysis of Fe: lignin nanoparticles without fusing), Sample 3 (lignin clusters are partially covered with $\mathrm{Fe}(\mathrm{OiPr})$ moieties when less $\mathrm{Fe}(\mathrm{OiPr})_{3}$ is used than the accessible $\mathrm{OH}$ groups in lignin), Sample 4 (hollow nanoparticles spheres are formed when less $\mathrm{Fe}(\mathrm{OiPr}) 3$ is used than the accessible OH groups). Scale bars in all TEM images are $200 \mathrm{~nm}$ 351, CRoyal Society of Chemistry (2016).

Recently, lignin nanoparticles (140 and $160 \mathrm{~nm}$ in size) have been fabricated fom softwood Kraft lignin in combination with tall oil fatty acid. These nanoparticles display better antimicrobial activity compared with silver nanospheres (10 $\mathrm{nm}$ in size) and Lignoboost lignin particles (300 and $400 \mathrm{~nm}$ in size) ${ }^{354}$. Other lignin nanoparticles with excellent antimicrobial activity in combination with antioxidant properties and thermal 
stability were synthesized following a relatively simple approach by dissolving alkali lignin into ethylene glycol under acidic conditions ${ }^{355}$. Moreover, spherical particles (80 and $140 \mathrm{~nm}$ in size) can be prepared from hardwood dioxane lignin and softwood alkali lignin using subabul stems and commercially available alkali lignin, respectively: the UV protection and antioxidant properties of dioxide lignin nanoparticles are higher than those of alkali lignin nanoparticles as confirmed during the analysis to protect E. coli against light irradiation ${ }^{356}$. The further functionalization of carboxylated Kraft lignin nanoparticles with block copolymers, such as polyethylene glycol, polymeric histidine, and cell-penetrating peptides, leads to an improvement in the $\mathrm{pH}$-sensitive anticancer drug delivery system. The features of these functionalized nanoparticles (good stability in biofluids, wide size distribution, and low cytotoxicity towards normal endothelial cells) are important for the successful release of water-insoluble anticancer agents based on $\mathrm{pH}$ sensitivity. ${ }^{357}$ Moreover, steam-exploded rice straw can yield lignin nanoparticles of $15-20 \mathrm{~nm}$ in size that are valuable for many industrial applications. The various approaches for the synthesis of lignin nanoparticles are summarized in Table 7.

Table 7. Methods to fabricate lignin nanoparticles 358, CRoyal Society of Chemistry (2020).

\begin{tabular}{|c|c|c|c|c|}
\hline Lignin source & $\begin{array}{l}\text { Size } \\
\text { (nm) }\end{array}$ & $\begin{array}{l}\text { Materials and } \\
\text { conditions }\end{array}$ & $\begin{array}{l}\text { Advantages and } \\
\text { disadvantages }\end{array}$ & Reference \\
\hline $\begin{array}{l}\text { Steam- } \\
\text { exploded rice } \\
\text { straw }\end{array}$ & $15-20$ & $\begin{array}{l}\text { Castor oil, ethylene } \\
\text { glycol, and water; acid } \\
\text { precipitation in polyol } \\
\text { medium that acts as a } \\
\text { stabilizing agent. }\end{array}$ & $\begin{array}{l}\text { Meets } 9 \text { of the } 12 \text { green } \\
\text { chemistry principles; } \\
\text { environment-friendly and } \\
\text { easy approach. }\end{array}$ & 359 \\
\hline $\begin{array}{l}\text { Alkaline } \\
\text { pretreated; } \\
\text { enzymatic } \\
\text { hydrolysis; } \\
\text { Kraft }\end{array}$ & $\begin{array}{l}80- \\
230\end{array}$ & $\begin{array}{l}\text { Self-assembly in } \\
\text { recyclable and non-toxic } \\
\text { aqueous sodium } p \text { - } \\
\text { toluene sulfonate at } \\
\text { room temperature, with } \\
\text { the lowest concentration } \\
\text { at } 48 \mathrm{~g} \mathrm{~L}^{-1}\end{array}$ & $\begin{array}{l}\text { Unfavorable } \\
\text { factors e.g. processing pH } \\
\text { and lignin species were } \\
\text { eliminated } \\
\text { hydrotropic chemistry } \\
\text { and the synergistic } \\
\text { dissociation of the } \\
\text { entrapped p-toluene } \\
\text { sulfonate and intrinsic } \\
\text { phenolic hydroxyl and } \\
\text { carboxylic acid moieties of } \\
\text { the lignin nanoparticles; } \\
\text { high yields }\end{array}$ & 360 \\
\hline
\end{tabular}




\begin{tabular}{|c|c|c|c|c|}
\hline Alkali & $\geq 100$ & $\begin{array}{l}\text { Lignin via microwave- } \\
\text { assisted acetylation } \\
\text { using acetic anhydride in } \\
\text { catalyst- and solvent-free } \\
\text { conditions; } \\
\text { anhydride serves acetic } \\
\text { reagent and dispersion } \\
\text { solvent. }\end{array}$ & $\begin{array}{l}\text { Nanoparticles are rapidly } \\
\text { produced without dialysis } \\
\text { and separated by } \\
\text { centrifugation; the applied } \\
\text { solvent can be recycled } \\
\text { and reused, which reduces } \\
\text { the cost; amenable for } \\
\text { industrial production; } \\
\text { easy and relatively green } \\
\text { method. }\end{array}$ & 361 \\
\hline Kraft & $\sim 38$ & $\begin{array}{l}\text { One-pot method via a } \\
\text { compressed } \\
\mathrm{CO}_{2} \text { antisolvent; } N, N- \\
\text { dimethylformamide to } \\
\text { produce lignin solution. }\end{array}$ & $\begin{array}{l}\text { High Brunauer-Emmett- } \\
\text { Teller surface area }(\sim 92 \\
\left.\mathrm{m}^{2} \mathrm{~g}^{-1}\right) \text { comprising } \\
\text { mesopores with relatively } \\
\text { high UV absorbing and } \\
\text { dispersion stability, } \\
\text { accelerated solubility, and } \\
\text { homogeneous thermal } \\
\text { degradation activity; easy } \\
\text { and environmentally } \\
\text { friendly method. }\end{array}$ & 362 \\
\hline $\begin{array}{l}\text { Waste } \\
\text { obtained from } \\
\text { Kraft pulping }\end{array}$ & $\begin{array}{l}200- \\
500\end{array}$ & $\begin{array}{l}\text { Water as non-solvent to } \\
\text { reduce lignin degrees of } \\
\text { freedom, causing the } \\
\text { segregation of } \\
\text { hydrophobic regions to } \\
\text { compartments within the } \\
\text { produced nanoparticles; } \\
\text { nanoparticles were } \\
\text { prepared during dialysis, } \\
24 \text { hours of slow stirring } \\
\text { in a fume hood. }\end{array}$ & $\begin{array}{l}\text { Simple process without } \\
\text { the need for chemical } \\
\text { modifications; } \\
\text { nanoparticles are surface } \\
\text { modifiable via adsorption } \\
\text { of oppositely charged } \\
\text { polyelectrolytes, the } \\
\text { potential for scale-up. }\end{array}$ & 363 \\
\hline $\begin{array}{l}\text { Natural } \\
\text { lignocellulose } \\
\text { source from } \\
\text { rice straw }\end{array}$ & $\sim 100$ & $\begin{array}{l}\text { Ethanol-water co- } \\
\text { solvent system with an } \\
\text { acid catalyst and one- } \\
\text { step microwave-assisted } \\
\text { method. }\end{array}$ & $\begin{array}{l}\text { Synchronous and rapid } \\
\text { preparation (10 min); } \\
\text { highly monodisperse and } \\
\text { stable lignin nanoparticles } \\
\text { with functional groups; } \\
\text { great potential for } \\
\text { biomedical applications. }\end{array}$ & 364 \\
\hline $\begin{array}{l}\text { Kraft and } \\
\text { organosolv }\end{array}$ & $\begin{array}{l}45- \\
250\end{array}$ & $\begin{array}{l}\text { Flash precipitation of the } \\
\text { dissolved lignin } \\
\text { polymer; colloidal } \\
\text { synthesis and interfacial } \\
\text { design of nanoparticles } \\
\text { with tunable surface } \\
\text { characteristics }\end{array}$ & $\begin{array}{l}\text { Fine-tunable surface } \\
\text { characteristics via coating } \\
\text { with a cationic } \\
\text { polyelectrolyte; control of } \\
\text { the nanoparticle surface } \\
\text { charge and stability in } \\
\text { strongly basic conditions }\end{array}$ & 349 \\
\hline
\end{tabular}




\begin{tabular}{|c|c|c|c|c|}
\hline & & & $\begin{array}{l}\text { with applications in } \\
\text { extreme pH conditions; } \\
\text { formulation of a } \\
\text { nanoparticle platform for } \\
\text { the generation of } \\
\text { sustainable delivery nano- } \\
\text { vehicles for } \\
\text { antimicrobials, fungicides, } \\
\text { pesticides, and drugs. } \\
\text { Upscalable } \\
\text { sustainable method. and }\end{array}$ & \\
\hline $\begin{array}{l}\text { Wheat straw } \\
\text { (herbaceous } \\
\text { biomass) }\end{array}$ & $70-90$ & $\begin{array}{l}\text { Choline chloride-lactic } \\
\text { acid-based deep eutectic } \\
\text { solvent extraction of } \\
\text { lignin nanoparticles from } \\
\text { herbaceous biomasses. }\end{array}$ & $\begin{array}{l}\text { High yields of very pure } \\
\text { and well-dispersed lignin } \\
\text { nanoparticles. }\end{array}$ & 365 \\
\hline $\begin{array}{l}\text { Bio-refined } \\
\text { comprising } \\
\text { grafted } \\
\text { carbohydrates }\end{array}$ & $\sim 100$ & $\begin{array}{l}\text { Nanoparticles from a } \\
\text { carbohydrate-rich lignin } \\
\text { fraction }(24 \% \text { by weight) } \\
\text { as insoluble fraction in } \\
0.5 \mathrm{M} \mathrm{NaOH} \text {. Dissolution } \\
\text { in a } \mathrm{NaOH} / \text { urea/water } \\
\text { system with dropwise } \\
\text { addition to water under } \\
\text { high shear, which } \\
\text { rapidly produces } \\
\text { precipitated particles. }\end{array}$ & $\begin{array}{l}\text { Green and sustainable } \\
\text { method; highly stable } \\
\text { particles. } \\
\text { nanoparticles, } \\
\text { contain carbohydrates and } \\
\text { lignin, can be used for } \\
\text { exclusive applications due } \\
\text { to their bi-component } \\
\text { nature. }\end{array}$ & 366 \\
\hline
\end{tabular}

\subsection{Lignin-based nanocomposites}

Carbon and carbon-based nanocomposites based on lignin are interesting due to their exclusive mechanical and electrical features, high temperature-related stability, stability towards pressure, resistance to attacks from acids, and the possibility of latency applications in microelectrodes, field emulsion transistors, and hydrogen storage. Lignins can be used as precursors for carbonaceous materials and converted into activated carbon, carbon catalysts, and carbon-based composite materials. ${ }^{367}$ The carbon-based micro- and nano-fibers could be produced by electrospinning a lignin solution at room temperature without adding any polymer. ${ }^{368}$ Lignin-based carbon/cerium phosphate $\left(\mathrm{CePO}_{4}\right)$ nanocomposites have been recently fabricated using a solvothermal method with non-aqueous or mixed solvent, which is considered a good approach for the fabrication of inorganic materials. The solvothermal approach provided elevated temperature and pressure conditions that favor lignin 
carbonization and the synthesis of $\mathrm{CePO}_{4}$ and carbon, thus reducing the cost of the synthesis of such composites. 369 Ultralight nanosized, lignin-graphene-derived carbon composite aerogels have been produced with enhanced elasticity and ultrahigh performance with electromagnetic intrusion shield. ${ }^{370}$ The carbon-zinc oxide nanocomposites based on a novel in-situ synthesis method resulted in excellent photocatalytic properties for the degradation of methyl orange (an organic pollutant dye) upon sunlight irradiation. ${ }^{371}$ In combination with other nanomaterials, the decoration of thin nanosized carbon tubes and nanosized poly (vinyl alcohol) with lignin provides nanoparticles with strong antibacterial activity. ${ }^{372}$

\subsection{Applications of lignin-based nanomaterials}

Lignin-based nanoparticles and nanostructures are gaining interest due to their unique applicability in drug delivery systems and a hydrophobic molecule delivery agent. The main drug carrier and delivery applications of lignin-based nanoparticles and their effective drug loading and releasing mechanisms are summarized in Figure 25. Drugs are loaded onto lignin-based nanoparticles by entrapment, encapsulation, and adsorption, and they are released via diffusion, swelling and dissolution, shell rupture, or desorption. Moreover, lignin-based nanoparticles display antioxidant and antimicrobial properties and are used as electrode material. ${ }^{346}$ The main properties of lignin are resistance to decay and attacks of biological origin, absorption of UV-radiation, high stiffness, and antioxidant activity. Therefore, lignin based-nanomaterials are tested in many applications, such as reinforcement material, UV blockers, biocides, antioxidants, radical scavengers, surfactants in Pickering emulsions, and nano or microcarrier. ${ }^{345,346,373}$ 


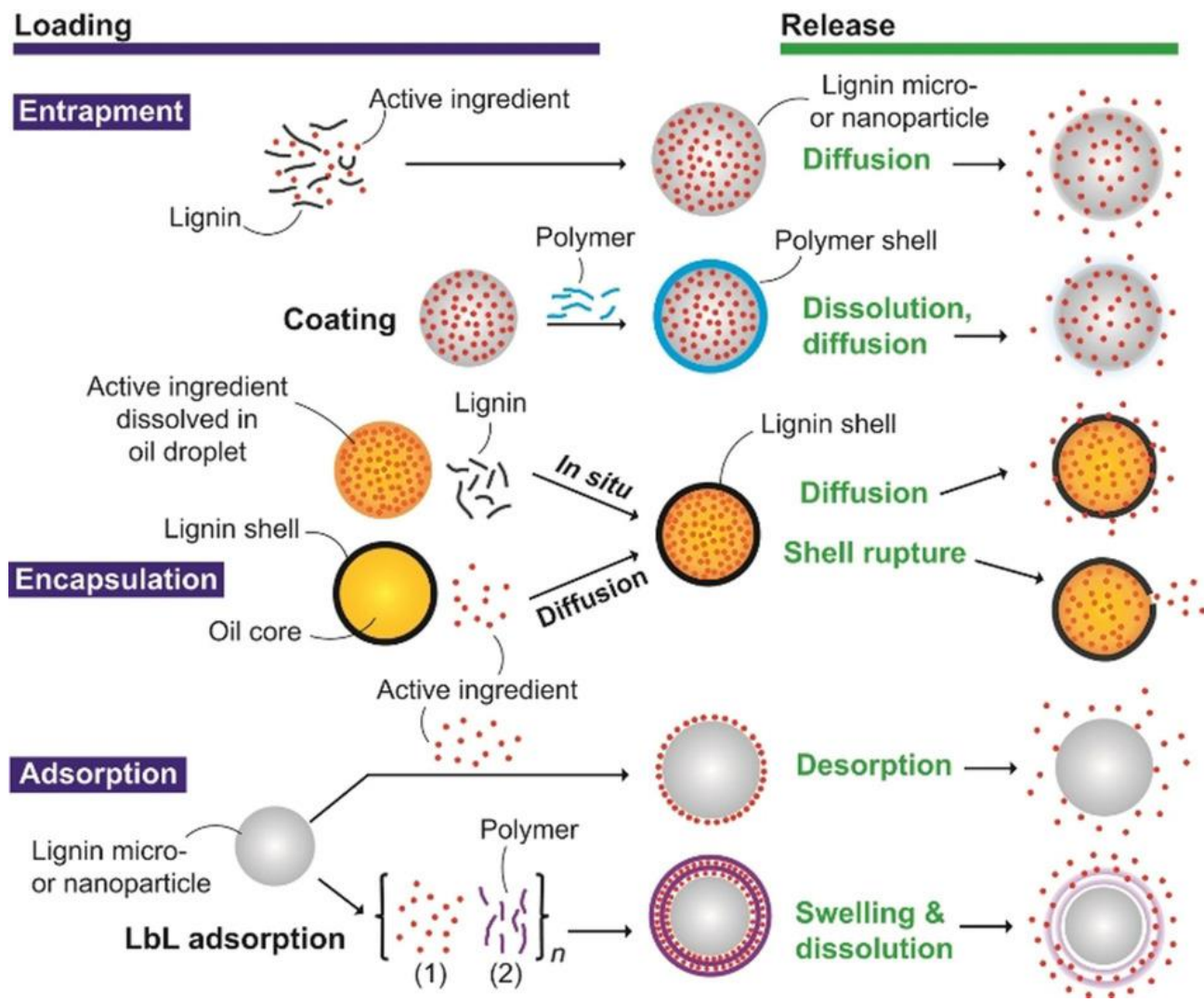

Figure 25. General methods for active substance loading onto and release from various lignin-based layer-by-layer (LBL) particulate and capsule carriers ${ }^{366}$, NC State University (2019).

The nanosized lignin particles can serve as an enhanced bio-additive for the fabrication of nanosized multifunctional composites as shown in Figure 26.374 The incorporation of porous lignin in poly(acrylic acid)/montmorillonite nanocomposites display enhanced swelling behavior for the rapid removal of lead ions from soil or water for environmental remediation applications. ${ }^{375}$ The lignin-based nanocomposite hydrogels also could be exploited for water purification, ${ }^{376}$ mainly including porous or hollow lignin composite nanospheres obtained with a Ziegler-Natta vanadium-based polymerization. ${ }^{377}$ The protective nanocomposite coatings or membranes of polyurethane-graphene-lignin are fabricated by an aqueous route that shows self-healing, UV-resistant, and electrical conductivity properties. ${ }^{378}$ Likewise, nano-lignin reinforced with chitosan present good sorbent ability to enhance the elimination of dye pollution from aqueous solutions as displayed in Figure 27.379 The other examples of recently fabricated lignin-based nanosized composites include, e.g., lignin-silica nanocomposites by grafting quaternary ammonium 
groups in softwood Kraft lignin with a core-shell structure and controlled mesopores as a sorbent, ${ }^{380}$ lignin nanosphere-polymer of vinyl alcohol nanocomposite with UV absorbing properties, ${ }^{381}$ nanosized lignin-polycaprolactone composites as tissue scaffolds, ${ }^{382}$ graphenelignin nanocomposite derivative of carbon film for energy storage application 383 and ligninbased magnesium hydroxide nanocomposite for toxic metal removal from aqueous medium. ${ }^{384}$ Table 8 summarizes the different applications of nanolignin materials.

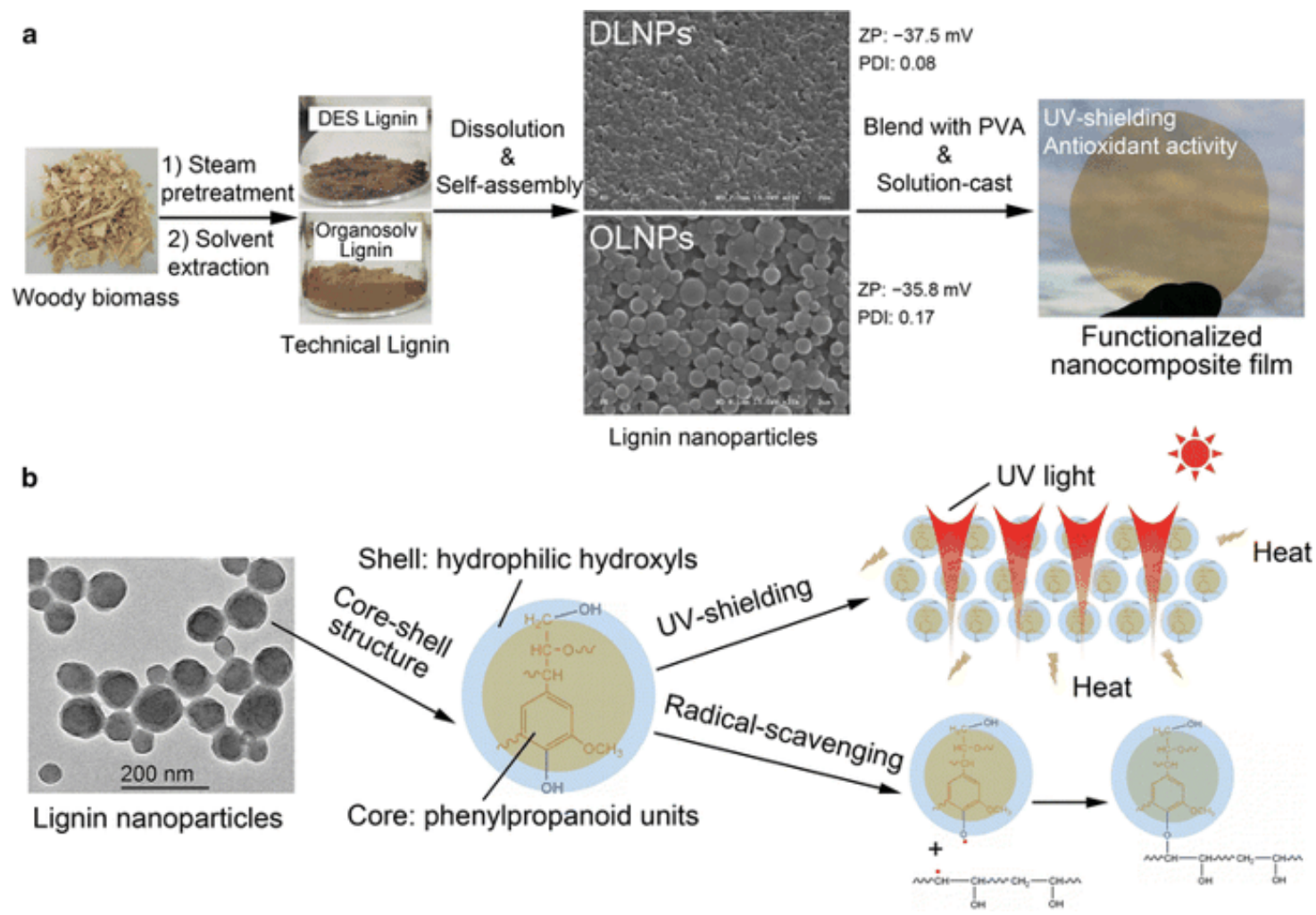

Figure 26. Route for the valorization of lignin into nanoparticles as a high-value bio-additive for multifunctional nanocomposites. (A) Synthesis of lignin nanoparticles and formation of a PVA/lignin nanocomposite film (ZP = Zeta-potential, PDI = polydispersity index). (B) Role of lignin nanoparticles as a functional additive with UV-shielding and antioxidant activity. 374 @) Springer Nature (2017). 


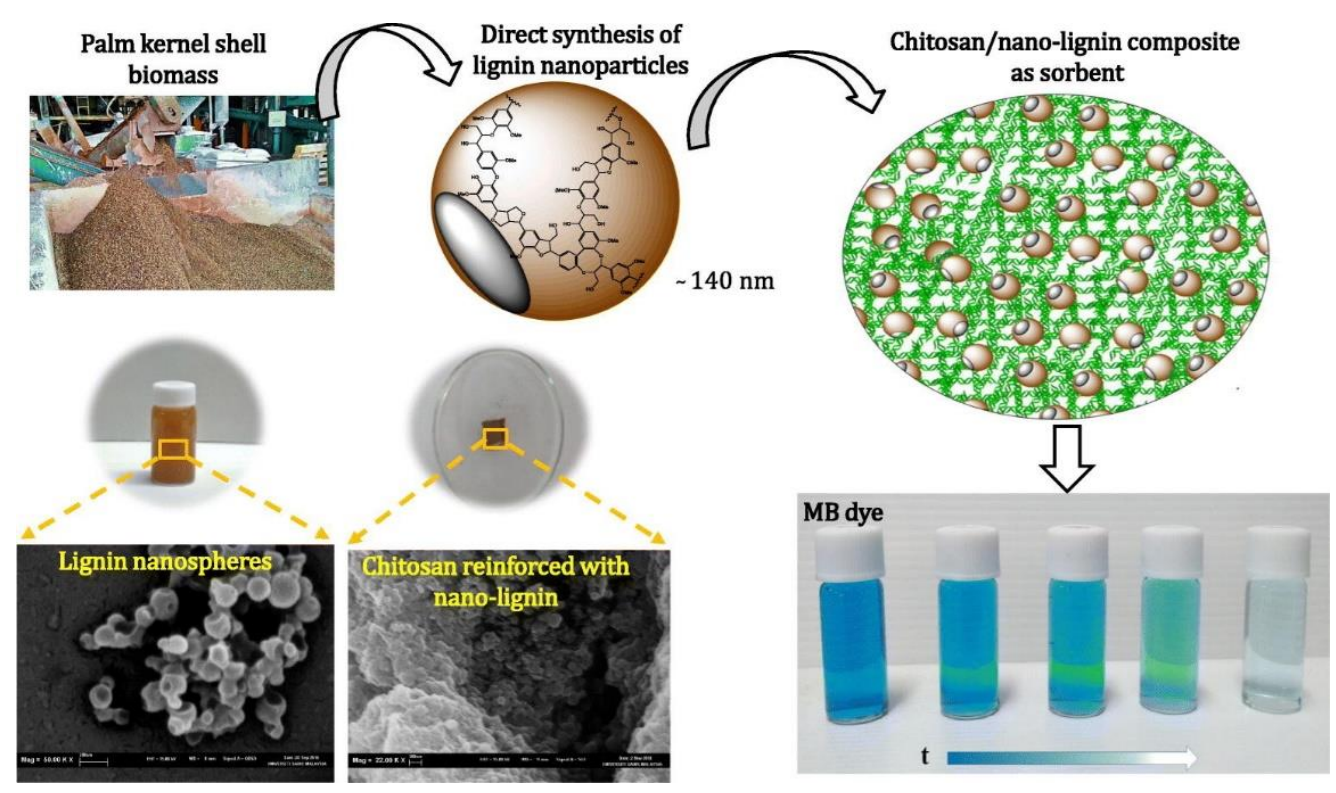

Figure 27. Lignin nanoparticles added into a chitosan nanocomposite as a sorbent for enhanced removal of polluting dye from an aqueous solution. ${ }^{379}$ OElsevier (2019).

Table 8. Applications of lignin-based nanosized composites

\begin{tabular}{|l|l|c|}
\hline Field of application & \multicolumn{1}{|c|}{ Description } & Reference \\
\hline Drug delivery & $\begin{array}{l}\text { Targeted, pH-responsive delivery of anticancer } \\
\text { drugs and oral delivery of curcumin }\end{array}$ & 357,385 \\
\hline Tissue engineering & Bone replacement material and bone regeneration & 386 \\
\hline Biomedical scaffolds & $\begin{array}{l}\text { Scaffolds to support tissue growth for bone } \\
\text { generation and mesenchymal stem cell proliferation } \\
\text { by acting as a substitute of the endocrine disruptor } \\
\text { bisphenol A (BPA) }\end{array}$ & 387 \\
\hline Bioimaging & $\begin{array}{l}\text { Lignin-derived reduced fluorescence carbon dots } \\
\text { and photoluminescent lignin hybridized carbon } \\
\text { quantum dots for bioimaging of cancer cells to } \\
\text { distinguish cytoplasm and nucleus }\end{array}$ & 388,389 \\
\hline Water treatment & $\begin{array}{l}\text { Lignin nanoparticle-gelatin based flocculant for S. } \\
\text { aureus and E. coli elimination from contaminated } \\
\text { water }\end{array}$ & 390 \\
\hline
\end{tabular}




\begin{tabular}{|c|c|c|}
\hline Batteries & $\begin{array}{l}\text { Lignin nanoparticle-coated Celgard separator for } \\
\text { high performance lithium-sulfur batteries and } \\
\text { flexible lignin-derived carbon nanofibers as lithium- } \\
\text { ion battery anodes }\end{array}$ & 391,392 \\
\hline Supercapacitors & $\begin{array}{l}\text { Nickel tungsten tetra-oxide nanoparticle-decorated } \\
\text { lignins as electrodes for asymmetrical flexible } \\
\text { supercapacitors, and lignin-derived highly porous } \\
\text { carbon monolith for high areal capacitance } \\
\text { supercapacitors }\end{array}$ & 393,394 \\
\hline Cosmetics & $\begin{array}{l}\text { Antioxidants, UV protectants, and broad-spectrum } \\
\text { sunscreens }\end{array}$ & 356,395 \\
\hline Foods & Food additives to protect from microbial attack & 396 \\
\hline Packing & $\begin{array}{l}\text { Antioxidant and antibacterial lignin nanoparticles in } \\
\text { polyvinyl alcohol-chitosan films and hydrogels for } \\
\text { active packages }\end{array}$ & 397,398 \\
\hline $\begin{array}{l}\text { Environmental } \\
\text { remediation }\end{array}$ & $\begin{array}{l}\text { Renewable building blocks, metal ion removal ability } \\
\text { and oil spill recovery for environmental remediation } \\
\text { of contaminated sites }\end{array}$ & $399-401$ \\
\hline
\end{tabular}

\section{Essential Oils}

Essential oils (EOs) are extracted from several parts of the plant as aromatic and volatile liquids, particularly originating from flowers and leaves but also from fruits, roots, seeds, and oleoresin exudations ${ }^{402}$. EOs are lipophilic semi-liquid phytochemicals with low molecular weight. The main constituents are terpenes (sesquiterpenoids, monoterpenoids, phenylpropanoids) and their byproducts that are self-assembled via the acetate-mevalonic acid pathway, aromatic compounds produced via shikimic-phenylpropanoid route, and other molecules from various origins. ${ }^{402}$ The huge EO variety is explained by the variability and complexity of their chemical composition, linked to the different plant parts from which they are extracted. The extraction methods also lead to EOs with distinct properties. These oils have a rather complex and diverse chemical composition and are used in the food industry or as fragrances in cosmetic and pharmaceutical industries in vaporizable 
formulations. The nanoformulations of EOs display, e.g., antimicrobial, antifungal, and antiviral activity or can be used as carriers for controlled release. ${ }^{403}$ They have been specifically used for biomedical applications due to anti-inflammatory, antimutagenic, antioxidant and anticarcinogenic properties, and other biological activities. ${ }^{404-406}$ Due to their aromatic nature, EOs are extensively used to produce soaps, perfumes, and toiletries.

\subsection{Essential oil extraction from leaves}

The term 'biomass extractives' describes the non-operational compounds that are retrieved by extraction in solvent media (e.g. water, ethanol, acetone, benzene, hexane, dichloromethane, and toluene): these include proteins, terpenes, starches, phenolics, essential oils, saponins, sterols, fatty acids, and flavonoid.407 They are commonly called phytochemicals, and they impart coloration to the wood and provide enhanced durability and toxicity against fungi and insects in natural materials. The lignocellulosic biomass also contains other components such as inorganic material (e.g., $\mathrm{Na}, \mathrm{K}, \mathrm{Ca}, \mathrm{Mg}$, Fe, Mn). During a pyrolysis reaction, the inorganic content decreases the yield of sugars obtained from cellulose and changes the characteristics of lignin products ${ }^{408}$.

The EOs are generally found as an ingredient in several medicinal plants. Conventional approaches for EO extraction are steam and hydrodistillation. One method for EO extraction from leaves is presented as an example in Figure 28, 411 but similar approaches or in combination with slight modifications can be used for the extraction from other plant parts. First, the plant leaves are isolated and subjected to hydrodistillation for the extraction of the EO using an improved Clevenger apparatus. After distillation, the volatile oils released from the leaves are collected in a reservoir, and sodium sulfate anhydrous is added to eliminate water. Then, the EO chemical composition can be identified by gas chromatography combined with mass spectrometry. 409 


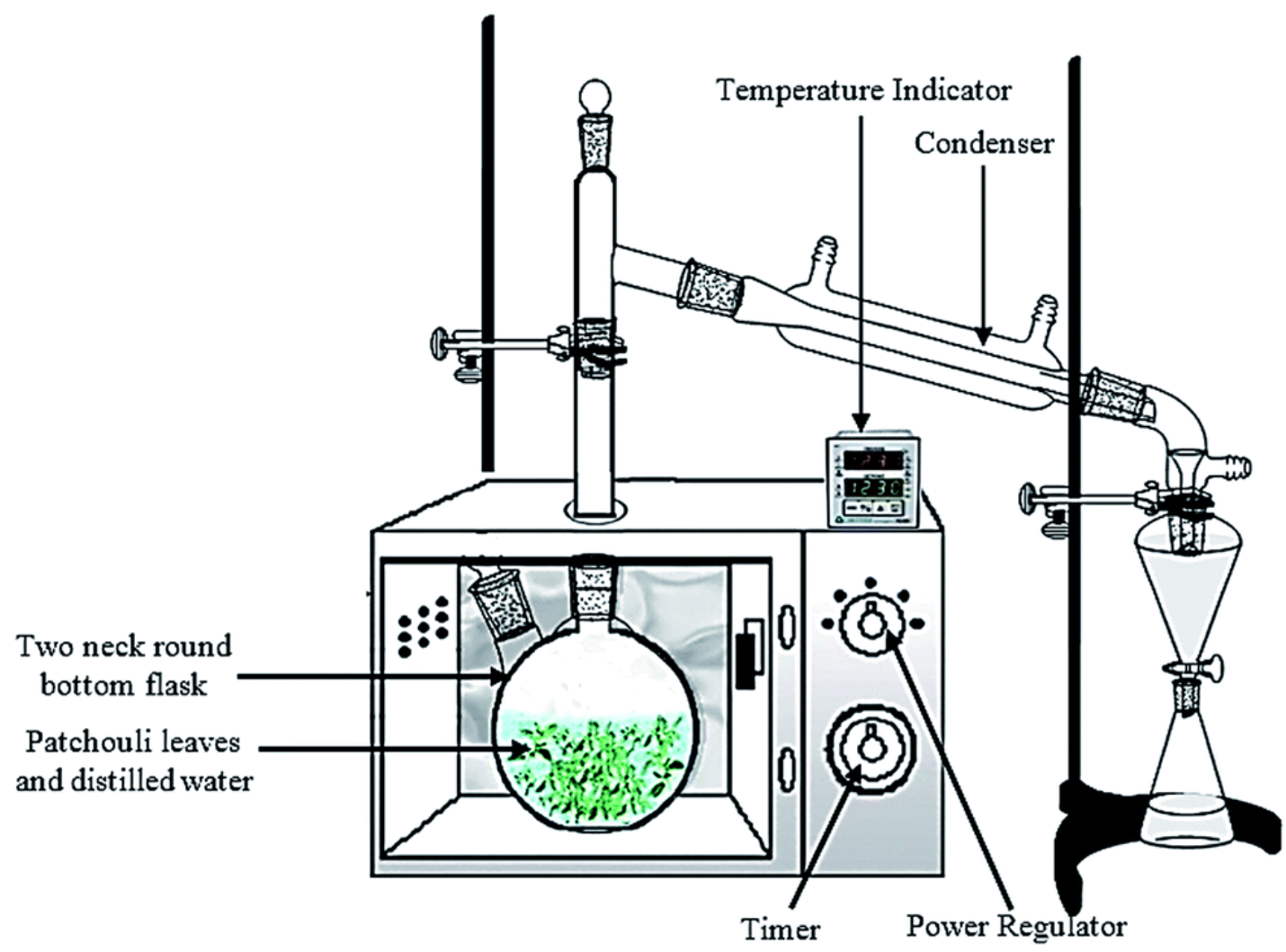

Figure 28. Extraction of patchouli oil utilizing a microwave-assisted hydro-distillation. ${ }^{410}$ (CRoyal Society of Chemistry (2017).

\subsection{Nanoparticle biosynthesis using essential oils}

The phytochemicals are isolated in plant extractives and play a major role in the biosynthesis and stabilization of nanosized particles. These phytochemicals are polyphenols and carotenoids, which include phenolic acid, flavonoids, and lignans. Flavonoids are subclassified in groups with a similar chemical edifice (anthocyanins, flavones, isoflavones, flavanones, and flavanols). Flavanols can be categorized in catechins, proanthocyanidins, and epicatechins ${ }^{411}$. Moreover, plant lipids, such as triglycerides, sterols, and phospholipids, influence the yield of nanosized particles. Also, the plant antioxidants (e.g. phenolics, carotenoids, anthocyanins, and tocopherols) are important materials for the production of nanosized particles ${ }^{412}$. Indeed, a broad range of nanoparticle types (i.e. metals ${ }^{413}$, metal oxides 414, carbon-based 415, polymeric nanoparticles 416, and nanocomposites 417) are synthesized using phytochemicals extracted from plants. Even plant-derived cellulose, lignin, and hemicellulose contain these phytochemicals. Thus, crude extracts are preferred for nanoparticle fabrication rather than purified components, because the synergistic effects 
of phytochemicals yield smaller and stable nanoparticles. These crude extracts have a role as stabilizers or reductants during the formation of nanoparticles, thereby replacing toxic chemicals and limiting the hazardous effects for humans and the environment. ${ }^{418}$

Currently, phytochemicals from living plants are used for nanoparticle production due to their wide availability. However, the destruction of plants for nanoparticle formation is not sustainable and not acceptable. For instance, as a collection of leaves for phytochemical extraction will affect plant growth, large-scale nanoparticle fabrication represents a threat for many plants. Therefore, plant and agriculture wastes are currently tested as a potential replacement for nanoparticles synthesis. Many studies have demonstrated that biowastes are a potential phytochemical source for the fabrication of nanosized particles. These biowastes can be categorized in crude waste (i.e. raw plant or agricultural wastes) and value-added waste. The major difference between crude and value-added biowastes is the processing time. As several impurities are present in crude agricultural wastes, several preprocessing and purification steps are often required, leading to longer production times. Microbial or enzymatic processes to transform them into value-added products for nanoparticle fabrication also require time. However, this process can contribute to tailoring the dimensions and shape of nanoparticles via optimization steps that are more time-consuming when using crude biowastes. Examples of crude wastes are Annona squamosa peel extracts used for silver nanoparticle synthesis 419 , banana peel extracts for nanosized palladium production, ${ }^{420}$ Vietnamese rice husk for silica nanoparticle fabrication, ${ }^{421}$ and Punica granatum peels for gold nanoparticle synthesis. ${ }^{422}$ Recent works reported the fabrication of nano-silica-based adsorbents from Saccharum officinarum leaf waste, ${ }^{423}$ zinc nanoparticles from various agricultural wastes, ${ }^{424}$ high-value nanoparticles from aquaculture and horticulture food waste, ${ }^{425}$ and coconut shell waste for silver nanoparticle formation. ${ }^{426}$

The value of agriculture wastes can be increased by adding chemicals or microbes to provide better conditions or stabilizing and reducing activities for the fabrication of nanosized particles ${ }^{427}$. For instance, the addition of activated carbon to agricultural wastes can be used to synthesize nanosized silver particles for the efficient catalytic reduction of nitrophenols. ${ }^{428}$ Similarly, sugarcane wastes are burned to obtain ash as a value-added process to fabricate pure silica nanoparticles with enhanced adsorption capacity. ${ }^{429}$ The 
addition of microbes to plant-based food wastes and agricultural waste biomass is used for the production of nanoparticles and nanostructured materials 430, 431 .

Generally, microbial and plant extracts are the main sources for nanoparticle biosynthesis from EOs. ${ }^{414}, 432$ On the other hand, microbial extract-mediated nanoparticle biosynthesis shows some limitations, particularly lack of nanoparticle stability, difficulty in downstream processing, and low yield in some cases. ${ }^{411}$ Therefore, EOs from plant sources are extensively employed in nanoparticle fabrication for several applications (Figure 29). The synthesized nanoparticles have EOs as their functional group and this will allow their internalization in target cells and biological activity. ${ }^{433}$ An overview of possible nanoparticles that are fabricated from these EOs for specific biomedical and pharmaceutical applications is listed in Table 9.

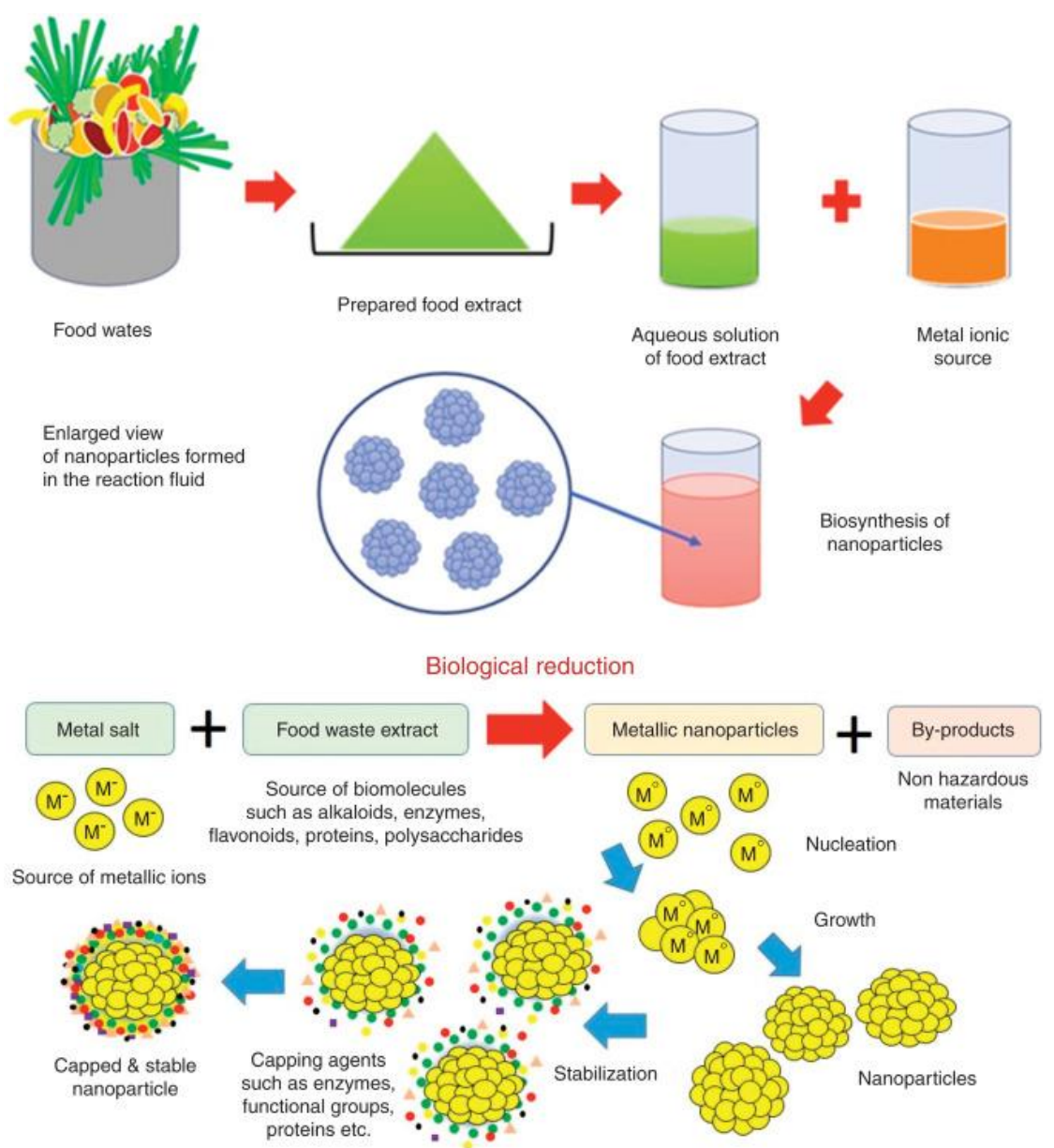

Figure 29. Biological synthesis routes in which EOs are used as an environmentally friendly source for nanoparticle production. ${ }^{434}$ CMDPI, (2017). 
Table 9. Summary of essential oils from various plant sources for nanoparticle synthesis

\begin{tabular}{|c|c|c|c|}
\hline Nanoparticles & Plant source & Morphology & Reference \\
\hline \multirow{5}{*}{ Silver nanoparticles } & Trachyspermum ammi & $\begin{array}{l}\text { Shape: } \\
\text { triangular } \\
\text { Size: } 87 \mathrm{~nm}\end{array}$ & 435 \\
\hline & $\begin{array}{l}\text { Tinospora } \\
\text { cordifolia Miers }\end{array}$ & $\begin{array}{l}\text { Shape: } \\
\text { agglomerated } \\
\text { spherical, } \\
\text { irregular shape } \\
\text { Size: } 55-80 \mathrm{~nm}\end{array}$ & 436 \\
\hline & Nelumbo nucifera & $\begin{array}{l}\text { Shape: } \\
\text { spherical, } \\
\text { triangular, } \\
\text { truncated } \\
\text { triangles, and } \\
\text { decahedral } \\
\text { Size: } 45 \mathrm{~nm}\end{array}$ & 437 \\
\hline & Bauhinia variegata & $\begin{array}{l}\text { Shape: } \\
\text { spherical, } \\
\text { triangular and } \\
\text { hexagonal } \\
\text { Size: } 38-65 \mathrm{~nm}\end{array}$ & 438 \\
\hline & Anisomeles indica & $\begin{array}{l}\text { Shape: spherical } \\
\text { Size: } 50 \text { - } 100 \mathrm{~nm}\end{array}$ & 439 \\
\hline & Anacardium occidentale & $\begin{array}{l}\text { Shape: } \\
\text { hexagonal } \\
\text { Size: } 36 \mathrm{~nm}\end{array}$ & 440 \\
\hline Gold nanoparticles & Tanacetum vulgare & $\begin{array}{l}\text { Shape: } \\
\text { triangular and } \\
\text { spherical } \\
\text { Size: } 10-40 \mathrm{~nm}\end{array}$ & 441 \\
\hline
\end{tabular}




\begin{tabular}{|c|c|c|c|}
\hline & Rosa damascene & $\begin{array}{l}\text { Shape: quasi- } \\
\text { spherical } \\
\text { Size: } 10-30 \mathrm{~nm}\end{array}$ & 442 \\
\hline & Elaeis guineensis & $\begin{array}{l}\text { Shape: } \\
\text { spherical, } \\
\text { triangular and } \\
\text { twinned } \\
\text { structures } \\
\text { Size: } 8-10 \mathrm{~nm}\end{array}$ & 443 \\
\hline & Lycoris aurea & $\begin{array}{l}\text { Shape: spherical } \\
\text { Size: } 24.1 \mathrm{~nm}\end{array}$ & 444 \\
\hline \multirow{3}{*}{$\begin{array}{l}\text { Platinum } \\
\text { nanoparticles }\end{array}$} & $\begin{array}{l}\text { Punica granatum peel } \\
\text { extract }\end{array}$ & $\begin{array}{l}\text { Shape: spheres } \\
\text { and cubes } \\
\text { Size: } 20.12 \mathrm{~nm}\end{array}$ & 445 \\
\hline & Saudi date extract & $\begin{array}{l}\text { Shape: spheres } \\
\text { of homogenous } \\
\text { shape } \\
\text { Size: } 1.3-2.6 \mathrm{~nm}\end{array}$ & 446 \\
\hline & $\begin{array}{l}\text { Alchornea laxiflora tree } \\
\text { bark extract }\end{array}$ & $\begin{array}{l}\text { Shape: spherical } \\
\text { Size: } \quad 3.68-8.77 \\
\mathrm{~nm}\end{array}$ & 447 \\
\hline \multirow{3}{*}{$\begin{array}{l}\text { Palladium } \\
\text { nanoparticles }\end{array}$} & $\begin{array}{l}\text { Coleus } \\
\text { aromaticus and Myristica } \\
\text { fragrans }\end{array}$ & $\begin{array}{l}\text { Shape: } \\
\text { Nanospheroid } \\
\text { clusters } \\
\text { Size: } 2.8 \mathrm{~nm}\end{array}$ & 448 \\
\hline & Phoenix dactylifera & $\begin{array}{l}\text { Shape: spherical } \\
\text { Size: } 13-21 \mathrm{~nm}\end{array}$ & 449 \\
\hline & $\begin{array}{l}\text { Boswellia serrata (Gum } \\
\text { olibanum) }\end{array}$ & $\begin{array}{l}\text { Shape: spherical } \\
\text { and poly- } \\
\text { dispersed }\end{array}$ & 450 \\
\hline
\end{tabular}




\begin{tabular}{|c|c|c|c|}
\hline & & Size: $2.5-8.8 \mathrm{~nm}$ & \\
\hline \multirow{3}{*}{$\begin{array}{l}\text { Zinc oxide } \\
\text { nanoparticles }\end{array}$} & Eucalyptus globulus & $\begin{array}{l}\text { Shape: spherical } \\
\text { Size: } 11.6 \mathrm{~nm}\end{array}$ & 451 \\
\hline & Spinacia oleracea & $\begin{array}{l}\text { Shape: - } \\
\text { Size: } \sim 20 \mathrm{~nm}\end{array}$ & 452 \\
\hline & Lemongrass lead & $\begin{array}{l}\text { Shape: } \\
\text { hexagonal } \\
\text { Size: 7-14 nm }\end{array}$ & 453 \\
\hline \multirow{3}{*}{$\begin{array}{l}\text { Iron oxide } \\
\text { nanoparticles }\end{array}$} & $\begin{array}{l}\text { Callistemon viminalis } \\
\text { flowers }\end{array}$ & $\begin{array}{l}\text { Shape: } \\
\text { patterned } \\
\text { spheres } \\
\text { Size: } 22-32 \mathrm{~nm}\end{array}$ & 454 \\
\hline & Carum carvi & $\begin{array}{l}\text { Shape: spherical } \\
\text { Size: }<300 \mathrm{~nm}\end{array}$ & 455 \\
\hline & $\begin{array}{l}\text { Pomegranate seed } \\
\text { extract }\end{array}$ & $\begin{array}{l}\text { Shape: semi- } \\
\text { spherical } \\
\text { uniform } \\
\text { particles } \\
\text { Size: } 25-55 \mathrm{~nm}\end{array}$ & 456 \\
\hline \multirow{3}{*}{$\begin{array}{l}\text { Titanium dioxide } \\
\text { nanoparticles }\end{array}$} & Echinacea purpurea & $\begin{array}{l}\text { Shape: spherical } \\
\text { clusters } \\
\text { Size: } 120 \mathrm{~nm}\end{array}$ & 457 \\
\hline & $\begin{array}{l}\text { Capsicum annum L. } \\
\text { and Allium cepa (onion) }\end{array}$ & $\begin{array}{l}\text { Shape: spherical } \\
\text { Size: 95.7, } 89.1 \text {, } \\
103.6 \text { and } 90.07 \\
\text { nm }\end{array}$ & 458 \\
\hline & Calotropis gigantea & $\begin{array}{l}\text { Shape: spherical } \\
\text { aggregates } \\
\text { Size: } 160-220 \mathrm{~nm}\end{array}$ & 459 \\
\hline
\end{tabular}




\begin{tabular}{|c|c|c|c|}
\hline & Camphor oil & $\begin{array}{l}\text { Shape: } \\
\text { multilayer tubes } \\
\text { Size: } 75 \mathrm{~nm} \\
\text { diameter }\end{array}$ & 460 \\
\hline Carbon nanotubes & $\begin{array}{l}\text { Coconut oil and olive } \\
\text { oil }\end{array}$ & $\begin{array}{l}\text { Shape: single- } \\
\text { walled tubes } \\
\text { Size: } 27-31 \mathrm{~nm} \text { in } \\
\text { diameter }\end{array}$ & 461 \\
\hline $\begin{array}{l}\text { Polymer-zinc } \\
\text { nanocomposites }\end{array}$ & Geranium oil & $\begin{array}{l}\text { Shape: thin films } \\
\text { Size: } 60-80 \mathrm{~nm}\end{array}$ & 462 \\
\hline $\begin{array}{l}\text { Clay-poly vinyl } \\
\text { pyrrolidone } \\
\text { nanocomposite }\end{array}$ & Syzygium aromaticum & $\begin{array}{l}\text { Shape: irregular } \\
\text { small sheets } \\
\text { Size: <100 nm }\end{array}$ & 463 \\
\hline $\begin{array}{l}\text { Zinc oxide-silver } \\
\text { nanocomposite }\end{array}$ & Wild ginger oil & $\begin{array}{l}\text { Shape: core- } \\
\text { shells } \\
\text { Size: } \sim 23 \mathrm{~nm}\end{array}$ & 464 \\
\hline
\end{tabular}

\subsubsection{Preparation of EO-based nanofibers}

The EO-based nanofibers are generally prepared by electrospinning using EO in water emulsion (i.e. emulsification). These nanofibers display antifungal and antibacterial activity and are used for cosmetic applications as material to provide fragrance. Such nanofibers are also employed as nano-scaffolds in tissue engineering. For instance, various concentrations of Mentha piperita and Salvia officinalis EOs diluted with Tween 80 have been used as an emulsifier for preparing the pre-polymer solution to produce solid nanofibers. ${ }^{465}$ EOs from cinnamon and beta-cyclodextrin proteoliposomes can be used to fabricate antibacterial polyethylene oxide nanofibers by electrospinning. ${ }^{466}$ The volatile cinnamon and oregano oils are part of a novel method for the fabrication of micro-sized beta-cyclodextrin capsules and nanosized films, offering excellent physical and antifungal properties against Botrytis fungi 467. An example of the fabrication of a cellulose nanofiber foam system for the sustained 
release of EO extracted from thyme is schematically drawn in Figure $30^{470}$, it clearly explains the mechanism of EO formation and its sustained release for food industry applications.

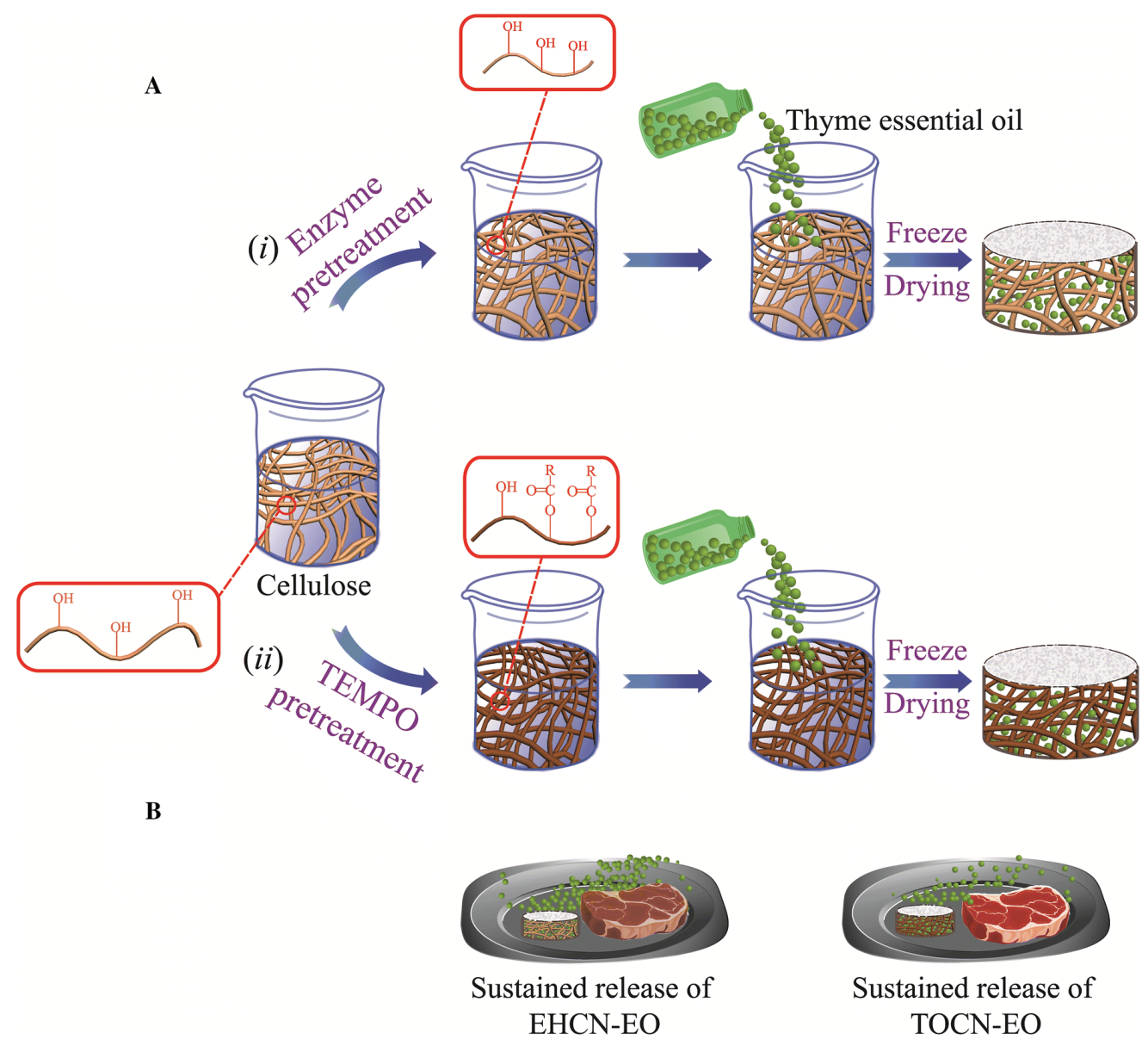

Figure 30. Sustained release of an EO using a hybrid cellulose nanofiber foam system ${ }^{468}$, () Springer Nature (2020).

\subsubsection{EO-based nanoemulsions}

The EO-based nanosized emulsions are a dispersion of oil in water with a droplet diameter of 10 to $100 \mathrm{~nm}$. They are among the novel strategies to inhibit mosquito vectors 469 and are also used for controlled drug delivery. ${ }^{470}$ Generally, nanoemulsions are formed by a top-down approach that involves oil-in-water emulsion formation by application of various homogenization techniques (e.g., ultrasonic, high-pressure, or multi-cycle microfluidic processing), as shown in Figure $31 .{ }^{471}$ The nanoemulsions can be fabricated using EOs extracted from Zataria multiflora, followed by immobilization on edible films from basil seed gum, presenting good antimicrobial agents against Gram-positive and Gram-negative 
bacterial strains while the mechanical properties are finally improved by the nanoemulsion addition ${ }^{472}$. These novel emulsion-based films could be used as antimicrobial food packages to inhibit pathogens present in food. Similarly, a nanoemulsion with $150 \mathrm{~nm}$ diameter droplets was produced using EOs extracted from Thymus daenensis. This nanoemulsion is stable for about 6 months and shows good antibacterial action against $E$. coli within $5 \mathrm{~min} 473$. Comparatively, the EO nanoemulsions with droplet size of $130 \mathrm{~nm}$ prepared from Satureja hortensis are stable for 1 month and have herbicidal activity against weeds (e.g. Chenopodium album and Amaranthus retroflexus). Specifically, they inhibit seed germination and root lengthening and reduce chlorophyll content in leaves ${ }^{474}$. These nanoemulsions show high physical stability, bioavailability, and optical transparency, and therefore are interesting also or the pharmaceutic, cosmetic, and food industries 475 .

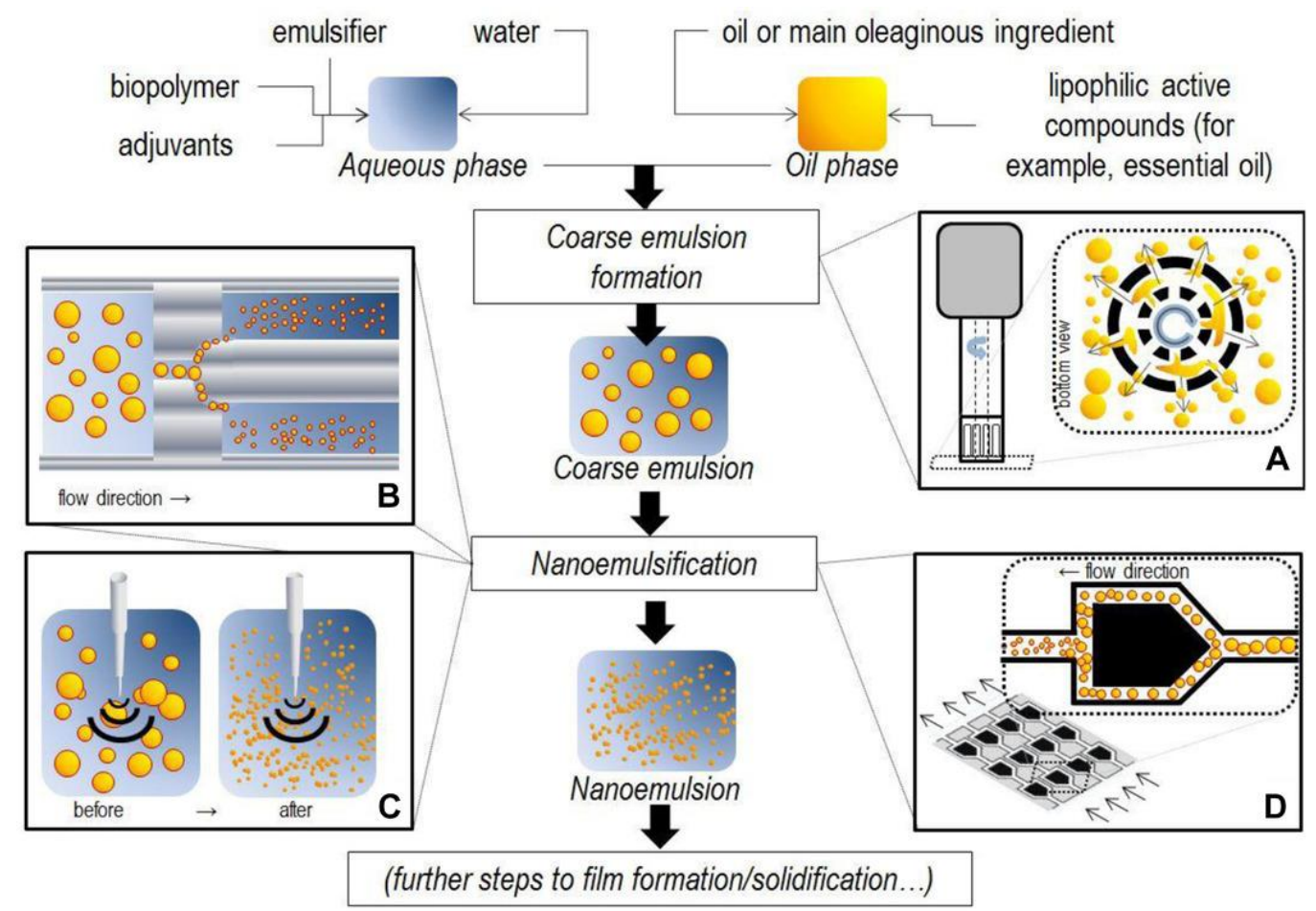

Figure 31. Methods for the fabrication of an EO nanoemulsion by means of a typical topdown approach. (A) Formation of a coarse oil-in-water emulsion by conventional high-speed mixers prior to emulsification. (B) Homogenization in a high-pressure valve, (C) Ultrasonic homogenization, (D) Multicycle high-pressure microfluidic homogenization with Y-shaped chambers ${ }^{471}$. @Institute of Food Technologists ${ }^{\circledR}$ (2018). 


\subsection{Applications of EO-based nanomaterials}

As the EOs possess main drawbacks, such as high volatility, rapid degradation, high lipophilicity, and limited permeability in the membrane, main applications should foresee in a stabilizing environment. Thus, for biomedical applications of EOs, nanocarriers are recommended to control the drug release in the desired tissue and to shield EOs against thermal and photo deprivation, oxidation and evaporation ${ }^{476}$. Nanocarrier systems are classified in lipid-based particles, nano-emulsions, and biocompatible polymeric particles, based on the materials from which they are fabricated. Each nanocarrier type can protect EOs in biological systems to enhance their controlled and targeted delivery ${ }^{403}$. Some authors have coupled antimicrobial EOs with inorganic nanosized carriers, such as oxides of metal-based materials and nano-clays, as a new delivery strategy. 477 Besides, polymeric nanoparticles (i.e. nanocapsules and nanospheres) can encapsulate antimicrobial EOs for controlled release, enhanced solubility in water, reduced toxicity towards cells, and higher antimicrobial efficacy. These polymeric nanocapsules and nanospheres can be added to commercial products, such as gels and creams, to improve EO activity and use in cosmetics and preservatives of pharmaceuticals ${ }^{478}$. Moreover, EO can be integrated in many nanosized lipid particles, such as liposomes, nanosized solid-liquid particles (SLNs), niosomes and lipid nanocarriers for drug delivery systems, to increase their biological activity and drug targeting efficiency 402,465 . Different methods, such as thin lipid film hydration and solvent in water emulsion diffusion, can be used to synthesize lipid nanoparticles, including liposomes and SLNs 479 .

\section{Semi-burned lignocellulose residues for nanoparticle synthesis}

While the burning of residual biomass is most commonly applied, intermediate valorization of semi-burned lignocellulose is gaining much attention as potentially reducing and stabilizing agent for nanoparticle fabrication. Rice husk is a main agricultural lignocellulosic side-product with physical-chemical properties as summarized in Table 10, which is used after semi-burning to produce nanoparticles and nanocomposites ${ }^{480}$. For instance, the rice husk ash after heat treatment was used in a sol-gel process with sodium hydroxide solution at $\mathrm{pH} 4$ and a water/butanol mixture to generate amorphous and uniform silica nanoparticles with a size of $3 \mathrm{~nm}$ and a specific surface value of $340 \mathrm{~m}^{2} / \mathrm{g}{ }^{481}$. 
As such, rice husk can also be used as an inexpensive precursor for the synthesis of silicon nanoparticles, e.g., by microwave heating 482: the resulting nanoparticles (diameter of $4.9 \mathrm{~nm}$, green luminescence, and $60 \%$ of quantum yield) were employed to fabricate white lightemitting diode bulbs with higher energy efficiency than a compact commercial fluorescent lamp. The fabrication of spherical silicon nanocrystals decorated with activated carbon derived from rice husks is depicted in Figure 32 (a), 483 resulting in composites with high porosity and specific surface area, low discharge potential and electrical conductivity: the material properties are interesting for its use as anode material in lithium-ion batteries. The novel composite-based lithium-ion battery displays favorable performance with high efficiency and could be applied for green energy storage devices ${ }^{483}$. The rice husk has also been used as a potential binder-free silicon dioxide precursor for silicon nanoparticles obtained by magnesiothermic reduction (Figure 32 (b)), ${ }^{484}$ which were bound with graphene material as an anode for lithium-ion batteries.

In general, various biomass residues such as corn cob, soybean shell, wheat bran, and rice husk are used for the conversion into activated carbon particles by means of an activation reaction in presence of sodium hydroxide. The resulting ash yields activated porous carbon particles with a very large surface area $\left(\sim 2500 \mathrm{~m}^{2} \mathrm{~g}^{-1}\right)$ employed for the adsorption of lead ions from contaminated environments (Figure 32 (c)) ${ }^{485}$. However, the use of semi-burned lignocellulose residues has some limitations related to the limited processing control, particularly resulting in variations in nanoparticle yield, performance, and stability. Indeed, its efficiency depends on the presence of active phytochemical substances and specific lignocellulosic composition, which represents a key challenge for its industrial use. ${ }^{486}$

Table 10. Physical and chemical properties of rice husk ash 487, @S Springer Nature (2012).

\begin{tabular}{|l|l|}
\hline \multicolumn{1}{|c|}{ Parameters } & \multicolumn{1}{c|}{ Values } \\
\hline Fineness passing 45 microns & $96 \%$ \\
\hline Specific surface for nitrogen absorption & $27400 \mathrm{~m}^{2} / \mathrm{kg}$ \\
\hline Specific gravity & 2.06 \\
\hline Silicon dioxide & $87.20 \%$ \\
\hline Aluminum oxide & $0.15 \%$ \\
\hline Ferric oxide & $0.16 \%$ \\
\hline
\end{tabular}




\begin{tabular}{|l|l|}
\hline Calcium oxide & $0.55 \%$ \\
\hline Magnesium oxide & $0.35 \%$ \\
\hline Sulphur trioxide & $0.24 \%$ \\
\hline Carbon & $5.91 \%$ \\
\hline Particle size & $7 \mu \mathrm{m}$ \\
\hline Loss on ignition & $5.44 \%$ \\
\hline Pozzolanic activity & $84 \%$ \\
\hline
\end{tabular}




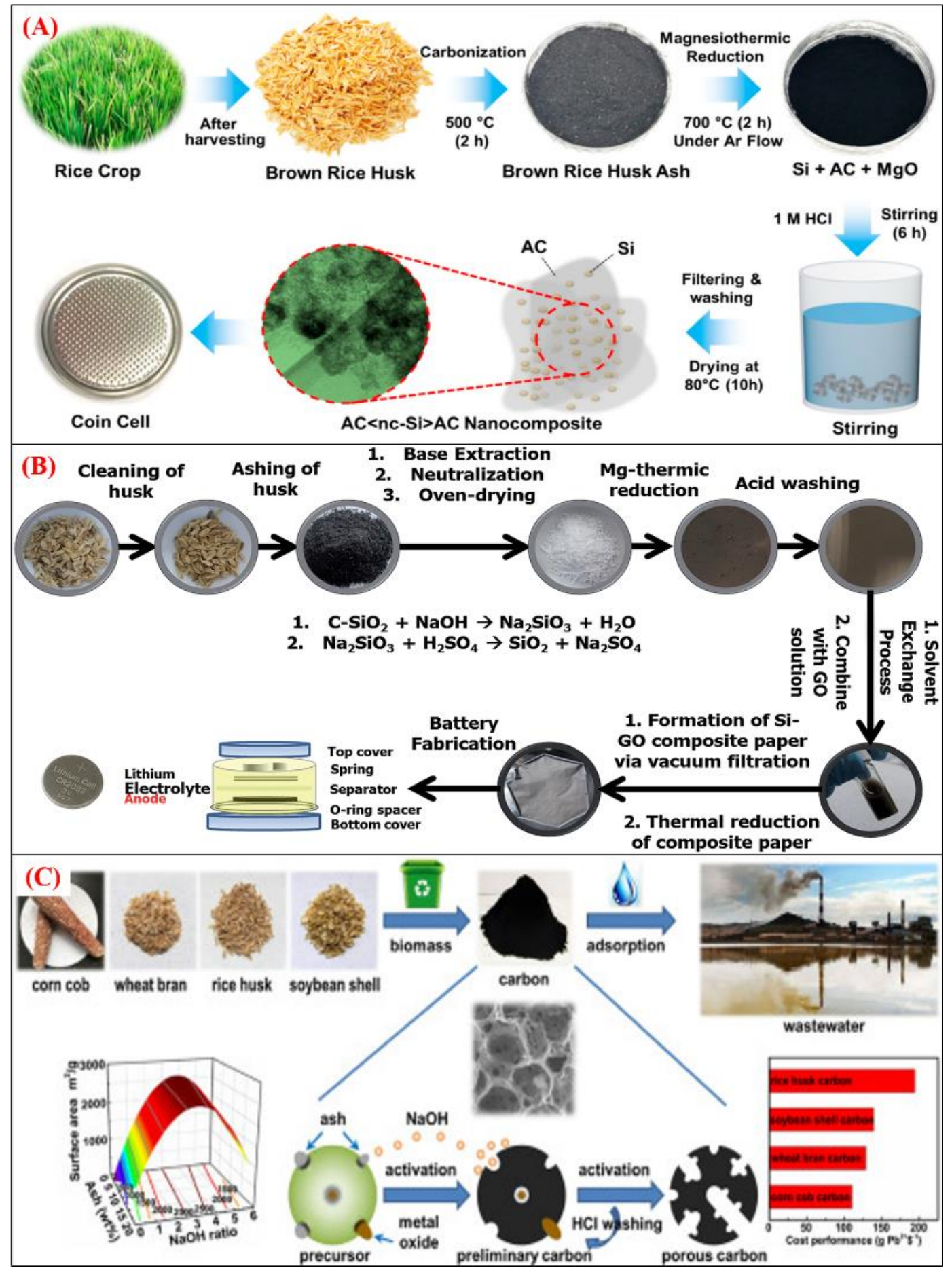

Figure 32. Transformation of semi-burnt brown riche husk into functional nanomaterials. (A) Synchronous derivation of activated-carbon-decorated silicon nanocrystal composites 483, OMDPI (2019). (B) Rice husk conversion into silicon nanoparticles, followed by composite paper fabrication with graphene oxide solution and battery fabrication 484, ORoyal Society of Chemistry (2014). (C) Production of activated carbon from various agricultural wastes as sources for wastewater treatment. 485 OElsevier (2020). 


\section{Risks, toxicity, and regulations}

Nanoparticles are generally fabricated using physical and chemical approaches for large-scale production that eventually might lead to their release in the environment ${ }^{488}$. In the environment, nanoparticles can harm humans and other living organisms, because they are often fabricated using toxic chemicals that act as functional groups and trigger hazardous metabolic reactions ${ }^{489}$. The nanoparticle size, morphology, surface charge, target cells, and chemical functional groups are main factors that influence the frequency of toxic reactions in an organism ${ }^{418}$. Thus, biological synthesis approaches have been introduced to reduce the risk linked to the release of chemical-based nanoparticles in the environment, and for safe use in biomedical applications ${ }^{490}$. As an advantage for the nanoparticles synthesized from natural resources, the phytosynthesized nanoparticles display enhanced biocompatibility with cells and mainly present a lower toxicity than the chemically synthesized particles ${ }^{491}$. However, phytosynthesized nanoparticles are not very stable, and this may increase their ability to agglomerate and form microsized particles that could be toxic ${ }^{492}$. The toxicity of phytosynthesized nanoparticles also depends on their dosage, aggregation, and concentration, size, and crystal structure, although biomolecules can be functionalized in these particles ${ }^{493}$. However, the complicated structure of phytochemicals and lack of current knowledge on the synergistic effect of phytochemicals in nanoparticle formation are the other limitations to be taken into account when using phytosynthesis as a potential alternative to chemical-based nanoparticle production ${ }^{494}$.

Although photosynthesis is used to fabricate non- to less-toxic nanoparticles, prior approval by regulatory agencies is required for their use in biomedical and pharmaceutical applications. The United States Food and Drug Administration and the European Medicine Agency are the two major regulatory bodies that approve nanoparticles for medical applications. Additionally, different countries have their own regulatory body to evaluate the toxicity and geographical implications of nanoparticle use in medicine. For instance, the United States Environmental protection Agency is the governing body to monitor nanoparticle use and the environmental consequences of their industrial applications in the USA. Noteworthy, very few nanoparticles have been approved by regulatory bodies for large-scale and widespread use in medicine and industry ${ }^{489}$. The phytosynthesized nanoparticles are still in their infancy and extensive research on phytochemistry and the 
mechanism of nanoparticle formation is required to replace chemical-based nanoparticles for potential applications ${ }^{495}$. Moreover, the use of phytochemicals from ethnobiological and medicinal plants for production of nanoparticles on the larger scale is strictly limited by bioprospecting and biopiracy laws in several countries ${ }^{496}$. In 2010, the Nagoya protocol was initiated in Japan with the aim of restricting access to genetic resources for profit to maintain biodiversity and reduce biopiracy ${ }^{497}$. Therefore, it is not possible to use indigenous plants for the large-scale production of novel nanoparticles for global usage because this may affect their existence in their native ecosystem ${ }^{498}$. Consequently, research efforts have been progressively focused on agricultural side-stream materials to obtain phytochemicals for nanoparticle production in order to overcome the current limitations.

\section{Conclusion}

Cellulose, hemicellulose, and lignin are considered copious polymers in nature with negligible toxicity, and therefore could be the answer to the challenges regarding material renewability, biodegradability, cost, and energy issues. Nanocelluloses, nanohemicelluloses, and lignin nanoparticles and their associated nanocomposites have demonstrated successful applications in biomedical research (i.e. biosensors, drug delivery, tissue engineering, medical implants, and wound healing), environmental protection and improvements (i.e. air filtration, water purification, wastewater treatment, sensing, and monitoring) and energy harvesting, production and storage (i.e. solar cells, fuel cells, hydrogen storage, batteries, supercapacitors), and constructing materials (i.e. papermaking, textiles, food packaging, automotive, aircraft). To promote the further commercialization and marketability of these nanomaterials, however, the applicability must be effortlessly ascendable and cheap leading to useful end-products. Up to present, most research on nanocelluloses, nano-hemicelluloses, and lignin nanoparticles production is mainly limited to the laboratory scale and only few attempts for industrial production have been initiated in the last five years. Current manufacturing approaches need to be constantly evaluated to produce environmentally accountable and economically achievable nanocelluloses, nanohemicelluloses and lignin nanoparticles. Still in a more early stage, similar limitations concern the employing of nanocelluloses, hemicelluloses, lignin, and essential oils for the production of inorganic nanoparticles at the pilot and large-scale production plants. 
As mentioned earlier, using live plants, plants or tree parts affects the growth of plants, and consequently agriculture and the environment. Therefore, it is not viable for large scale production. The main focus should therefore be put on the recovery of plant and agricultural residues that represent an alternative source for the generation of bionanoparticles. In the future, it should be viable to replace traditional chemical-based nanoparticle fabrication methods that are environmentally hazardous by plant-based reducing and stabilizing agents for the production of biocompatible, bioavailable, bioactive, and non-toxic nanoparticles. New methods for better control on the production of metal and metal oxide nanoparticles from nanocelluloses, nano-hemicelluloses, and nano-lignin substrates as dictated by the ultimate application will help generate optimal performances and could form the basis of engineering novel nanocomposite materials for sustainable applications. Therefore, research efforts targeted at regenerating or extending the life of nanocomposites of nanocellulose, nano-hemicellulose, and nano-lignin will promote the sustainable and more rational use of available plant materials on earth.

\section{Acknowledgments}

The authors acknowledge the support of FCT-Fundação para a Ciência e a Tecnologia (Base Fund UIDB/00674/2020 and Programmatic Fund UIDP/00674/2020, Portuguese Government Funds), ARDITI-Agência Regional para o Desenvolvimento da Investigação Tecnologia e Inovação through the project M1420-01-0145-FEDER-000005-CQM+ (Madeira 14-20 Program). Very special thanks to the Egypt-France Joint Driver (Imhotep, Project No. 43990SF, 2020-2022) for giving Ass. Prof. Ahmed Barhoum (Lecturer of Nanotechnology at Helwan University and Project PI) the opportunity and financial support to pursue a research stay at the Institut Européen des Membranes (IEM).

\section{References}

1. A. Husen and K. S. Siddiqi, Nanoscale Res. Lett., 2014, 9, 229.

2. R. W. Hartel, H. Joachim and R. Hofberger, in Confectionery Science and Technology, Springer, 2018, pp. 125-150.

3. A. K. Parida, A. Kumari, A. Panda, J. Rangani and P. K. Agarwal, Biol. Plant., 2018, 62, 343-352.

4. G. R. Schinella, H. A. Tournier, J. M. Prieto, P. M. De Buschiazzo and J. L. Rıos, Life sciences, 2002, 70, 1023-1033.

5. H. M. C. Azeredo, Int. J. Adv. Med., 2018, 1, 2-6. 
6. J. S. Brigham, W. S. Adney and M. E. Himmel, in Handbook on Bioethanol, Routledge, 2018, pp. 119141.

7. H. Renault, D. Werck-Reichhart and J.-K. Weng, Curr. Opin. Biotechnol., 2019, 56, 105-111.

8. A. K. Pandey, P. Kumar, P. Singh, N. N. Tripathi and V. K. Bajpai, Front. Microbiol., 2017, 7, 2161.

9. T. Voisin, A. Erriguible, D. Ballenghien, D. Mateos, A. Kunegel, F. Cansell and C. Aymonier, J. Supercrit. Fluids, 2017, 120, 18-31.

10. V. Guna, M. Ilangovan, C. Hu, G. S. Nagananda, M. G. Ananthaprasad, K. Venkatesh and N. Reddy, J. Nat. Fibers, 2019, 1-10.

11. J. Sunthornvarabhas, S. Liengprayoon and T. Suwonsichon, Ind. Crops Prod., 2017, 109, 857-861.

12. M. N. Collins, M. Nechifor, F. Tanasă, M. Zănoagă, A. McLoughlin, M. A. Stróżyk, M. Culebras and C.-A. Teacă, Int. J. Biol. Macromol., 2019.

13. J. Deng, T. Xiong, H. Wang, A. Zheng and Y. Wang, ACS Sustainable Chem. Eng., 2016, 4, 3750-3756.

14. Z. Liu, D. Xu, L. Xu, F. Kong, S. Wang and G. Yang, Polymers, 2018, 10, 743.

15. A. M. Adel, A. A. El-Gendy, M. A. Diab, R. E. Abou-Zeid, W. K. El-Zawawy and A. Dufresne, Ind. Crops Prod., 2016, 93, 161-174.

16. L. B. Tavares, N. M. Ito, M. C. Salvadori, D. J. dos Santos and D. S. Rosa, Polym. Test., 2018, 67, 169176.

17. R. Rampazzo, D. Alkan, S. Gazzotti, M. A. Ortenzi, G. Piva and L. Piergiovanni, Packag. Technol. Sci., 2017, 30, 645-661.

18. J. Domínguez-Robles, S. A. Stewart, A. Rendl, Z. González, R. F. Donnelly and E. Larrañeta, Biomolecules, 2019, 9, 423.

19. J. Moohan, S. A. Stewart, E. Espinosa, A. Rosal, A. Rodríguez, E. Larrañeta, R. F. Donnelly and J. Domínguez-Robles, Appl. Sci., 2020, 10, 65.

20. B. Qi, C. Wang, J. Ding and W. Tao, Front. Pharmacol., 2019, 10.

21. A. Barhoum, M. Rehan, H. Rahier, M. Bechelany and G. Van Assche, ACS Appl. Mater. Interfaces, 2016, 8, 10551-10561.

22. M. Rehan, T. A. Khattab, A. Barohum, L. Gätjen and R. Wilken, Carbohydr. Polym., 2018, 197, 227-236.

23. M. Rehan, A. Barhoum, G. Van Assche, A. Dufresne, L. Gätjen and R. Wilken, Int. J. Biol. Macromol., 2017, 98, 877-886.

24. A. Rastogi, P. Singh, F. A. Haraz and A. Barhoum, in Fundamentals of Nanoparticles, eds. A. Barhoum and A. S. Hamdy Makhlouf, Elsevier, 2018, DOI: https://doi.org/10.1016/B978-0-323-51255-8.00023g, pp. 571-604.

25. D. Klemm, F. Kramer, S. Moritz, T. Lindström, M. Ankerfors, D. Gray and A. Dorris, Angew. Chem., Int. Ed., 2011, 50, 5438-5466.

26. Y. Y. Tye, K. T. Lee, W. N. W. Abdullah and C. P. Leh, Renewable Sustainable Energy Rev., 2016, 60, 155172.

27. Y. Ogasawara, Y. Hidano and Y. Kato, J. Jpn. Soc. Food Sci., 2006.

28. S. S. Behera and R. C. Ray, in Bioethanol Production from Food Crops, eds. R. C. Ray and S. Ramachandran, Academic Press, 2019, DOI: https://doi.org/10.1016/B978-0-12-813766-6.00012-6. pp. 233-247.

29. J. E. Bidlack and D. R. Buxton, Can. J. Plant Sci., 1992, 72, 809-818.

30. R. Verma, M. Awasthi, R. Modgil and Y. S. Dhaliwal, 2012.

31. G. J. Kulić and V. B. Radojičić, J. Agric. Sci, Belgrade, 2011, 56, 207-215.

32. R. M. Sheltami, I. Abdullah, I. Ahmad, A. Dufresne and H. Kargarzadeh, Carbohydr. Polym., 2012, 88, 772-779.

33. C. F. Liu, F. Xu, J. X. Sun, J. L. Ren, S. Curling, R. C. Sun, P. Fowler and M. S. Baird, Carbohydr. Res., 2006, 341, 2677-2687.

34. C. F. Chau and Y. L. Huang, Food Chem., 2004, 85, 189-194.

35. Y. Habibi, L. Heux, M. Mahrouz and M. R. Vignon, Carbohydr. Polym., 2008, 72, 102-112.

36. M. S. Nazir, B. A. Wahjoedi, A. W. Yussof and M. A. Abdullah, BioResources, 2013, 8, 2161-2172.

37. M. Szymańska-Chargot, M. Chylińska, K. Gdula, A. Kozioł and A. Zdunek, Polymers, 2017, 9. 
38. F. Cherubini, Energy Convers. Manage., 2010, 51, 1412-1421.

39. V. Menon and M. Rao, Prog. Energy Combust. Sci., 2012, 38, 522-550.

40. M. A. Held, N. Jiang, D. Basu, A. M. Showalter and A. Faik, Polysaccharides: bioactivity and biotechnology, 2015, 3-54.

41. N. C. Carpita and M. C. McCann, Plant and soil, 2002, 247, 71-80.

42. P. J. Harris, N. Z. J. For. Sci., 2006, 36, 36.

43. A. Ebringerova and T. Heinze, Macromol. Rapid Commun., 2000, 21, 542-556.

44. A. Oikawa, C. H. Lund, Y. Sakuragi and H. V. Scheller, Trends Plant Sci., 2013, 18, 49-58.

45. F. A. Pettolino, C. Walsh, G. B. Fincher and A. Bacic, Nat. Protoc., 2012, 7, 1590.

46. M. Chylińska, M. Szymańska-Chargot and A. Zdunek, Plant Methods, 2014, 10, 14.

47. M. Pauly and K. Keegstra, Annu. Rev. Plant Biol., 2016, 67, 235-259.

48. C. Voiniciuc, M. Pauly and B. Usadel, Plant Physiol., 2018, 176, 2590-2600.

49. Hiroshi Nishimura, Akihiro Kamiya, Takashi Nagata, Masato Katahira \& Takashi Watanabe, Scientific Reports volume 8, Article number: 6538 (2018)

50. R. L. Crawford, Lignin biodegradation and transformation, John Wiley and Sons., 1981.

51. A. Payen, Comptes rendus, 1838, 7, 1052-1056.

52. R. Young and R. M. Rowell, Cellulose: structure, modification and hydrolysis, 1986.

53. H. Staudinger, Berichte der deutschen chemischen Gesellschaft (A and B Series), 1920, 53, 1073-1085.

54. K. Freudenberg, Berichte der deutschen chemischen Gesellschaft (A and B Series), 1921, 54, 767-772.

55. W. N. Haworth and H. Machemer, Journal of the Chemical Society (Resumed), 1932, DOI: 10.1039/JR9320002270, 2270-2277.

56. C. Bonechi, M. Consumi, A. Donati, G. Leone, A. Magnani, G. Tamasi and C. Rossi, in Bioenergy Systems for the Future, Elsevier, 2017, pp. 3-42.

57. S. PÉrez and D. Samain, in Advances in carbohydrate chemistry and biochemistry, Elsevier, 2010, vol. 64, pp. 25-116.

58. C. Hongzhang, BIOTECHNOLOGY OF LIGNOCELLULOSE: Theory and Practice, SPRINGER, 2016.

59. C. Bishop, Vacuum deposition onto webs, films and foils, William Andrew, 2011.

60. C. Krumm, J. Pfaendtner and P. J. Dauenhauer, Chem. Mater., 2016, 28, 3108-3114.

61. H. A. Tayeb, E. Amini, S. Ghasemi and M. Tajvidi, Molecules, 2018, 23.

62. P. Nehra and R. P. Chauhan, Journal of Biomaterials Science, Polymer Edition, 2020, DOI: 10.1080/09205063.2020.1817706, 1-38.

63. X. Wang, C. Yao, F. Wang and Z. Li, Small, 2017, 13, 1702240.

64. T.-W. Zhang, T. Tian, B. Shen, Y.-H. Song and H.-B. Yao, Compos. Commun., 2019, 14, 7-14.

65. G. Pandey, Sep. Purif. Technol., 2019, 1, 408.

66. D. Palai and M. Khandelwal, 2019.

67. R. Sunasee, U. D. Hemraz and K. Ckless, Expert Opin. Drug Delivery, 2016, 13, 1243-1256.

68. R. J. Moon, A. Martini, J. Nairn, J. Simonsen and J. Youngblood, Chem. Soc. Rev., 2011, 40, 3941-3994.

69. S. Bagheri, N. M. Julkapli and N. Mansouri, Handbook of Composites from Renewable Materials, 2017, 523-555.

70. A. Naderi, Cellulose, 2017, 24, 1933-1945.

71. F. Ansari and L. A. Berglund, in Multifunctional Polymeric Nanocomposites Based on Cellulosic Reinforcements, Elsevier, 2016, pp. 115-130.

72. P. L. Kumari, N. Sreenivasulu and P. Dinesh Sanker Reddey, Int. adv. res. j. sci. eng., 2016, 5, 364-374.

73. K.-Y. Lee, G. Buldum, A. Mantalaris and A. Bismarck, Macromol. Biosci., 2014, 14, 10-32.

74. S.-P. Lin, I. Loira Calvar, J. M. Catchmark, J.-R. Liu, A. Demirci and K.-C. Cheng, Cellulose, 2013, 20, 21912219.

75. K.-Y. Lee, T. Tammelin, K. Schulfter, H. Kiiskinen, J. Samela and A. Bismarck, ACS Appl. Mater. Interfaces, 2012, 4, 4078-4086.

76. C. Lai, S. Zhang, L. Sheng, S. Liao, T. Xi and Z. Zhang, Colloid Polym. Sci., 2013, 291, 2985-2992.

77. D. Lin, R. Li, P. Lopez-Sanchez and Z. Li, Food Hydrocolloids, 2015, 44, 435-442.

78. H. Kargarzadeh, M. Ioelovich, I. Ahmad, S. Thomas and A. Dufresne, Journal, 2017, 1-49. 
79. M. Kaushik and A. Moores, Green Chem., 2016, 18, 622-637.

80. K. Yuwawech, J. Wootthikanokkhan and S. Tanpichai, J. Nanomater., 2015, 16, 69.

81. O. Nechyporchuk, M. N. Belgacem and J. Bras, Ind. Crops Prod., 2016, 93, 2-25.

82. G. Siqueira, J. Bras and A. Dufresne, Polymers, 2010, 2, 728-765.

83. K. P. Y. Shak, Y. L. Pang and S. K. Mah, Beilstein J. Nanotechnol., 2018, 9, 2479-2498.

84. M. A. S. Azizi Samir, F. Alloin and A. Dufresne, Biomacromolecules, 2005, 6, 612-626.

85. M. loelovich, Am. J. Nanosci. Nanotechnol., 2013, 1, 41-45.

86. M. loelovich, TAPPI J, 2014, 13, 45-51.

87. M. Beaumont, S. Rosenfeldt, B. L. Tardy, C. Gusenbauer, A. Khakalo, Nonappa, M. Opietnik, A. Potthast, O. J. Rojas and T. Rosenau, Nanoscale, 2019, 11, 17773-17781.

88. J. Al Hakkak, W. J. Grigsby, K. Kathirgamanathan and N. R. Edmonds, Adv. Mater. Sci. Eng., 2019, 2019.

89. C. Clemons, J. Renewable Mater., 2016, 4, 327-339.

90. A. Barhoum, H. H. El-Maghrabi, I. latsunskyi, E. Coy, A. Renard, C. Salameh, M. Weber, S. Sayegh, A. A. Nada and S. Roualdes, J. Colloid Interface Sci., 2020, 569, 286-297.

91. D. Gugulothu, in Handbook of Nanofibers, Springer International Publishing Cham, 2018, pp. 1-34.

92. L. Haichao, L. Haoyi, M. M. Bubakir, Y. Weimin and A. Barhoum, Handbook of Nanofibers; Springer International Publishing: Cham, Switzerland, 2018, 1-27.

93. M. Bubakir, H. Li, A. Barhoum and Y. Yang, Handbook of Nanofibers; Barhoum, A., Bechelany, M., Makhlouf, AH, Eds, 2018, 1-30.

94. M. W. Frey, Polym. Rev., 2008, 48, 378-391.

95. S. O. Han, W. K. Son, J. H. Youk and W. H. Park, J. Appl. Polym. Sci., 2008, 107, 1954-1959.

96. M. J. Lundahl, V. Klar, L. Wang, M. Ago and O. J. Rojas, Ind. Eng. Chem. Res., 2017, 56, 8-19.

97. M. J. Lundahl, V. Klar, R. Ajdary, N. Norberg, M. Ago, A. G. Cunha and O. J. Rojas, ACS Appl. Mater. Interfaces, 2018, 10, 27287-27296.

98. J. Araki and M. Miyayama, Polymer, 2020, 188, 122116.

99. T. Budtova, Cellulose, 2019, 26, 81-121.

100. L.-Y. Long, Y.-X. Weng and Y.-Z. Wang, Polymers, 2018, 10, 623.

101. A. Zaman, F. Huang, M. Jiang, W. Wei and Z. Zhou, Energy and Built Environment, 2019.

102. A. Sanguanwong, P. Pavasant, T. Jarunglumlert, K. Nakagawa, A. Flood and C. Prommuak, Nord. Pulp Pap. Res. J., 2020, 35, 137-147.

103. R. Lin, A. Li, T. Zheng, L. Lu and Y. Cao, RSC Adv., 2015, 5, 82027-82033.

104. M. Zhu, Y. Wang, S. Zhu, L. Xu, C. Jia, J. Dai, J. Song, Y. Yao, Y. Wang and Y. Li, Adv. Mater., 2017, 29, 1606284.

105. X. Han, Y. Ye, F. Lam, J. Pu and F. Jiang, J. Mater. Chem. A, 2019, 7, 27023-27031.

106. L. Chen, N. Song, L. Shi and P. Ding, Composites, Part A, 2018, 112, 18-24.

107. S. Wang, T. Li, C. Chen, W. Kong, S. Zhu, J. Dai, A. J. Diaz, E. Hitz, S. D. Solares and T. Li, Adv. Funct. Mater., 2018, 28, 1707491.

108. D. Ye, Q. Cheng, Q. Zhang, Y. Wang, C. Chang, L. Li, H. Peng and L. Zhang, ACS Appl. Mater. Interfaces, 2017, 9, 43154-43162.

109. D. Ye, X. Lei, T. Li, Q. Cheng, C. Chang, L. Hu and L. Zhang, ACS nano, 2019, 13, 4843-4853.

110. J. W. Kim, S. Park, D. P. Harper and T. G. Rials, J. Appl. Polym. Sci., 2013, 128, 181-187.

111. L. I. Jian and W. A. N. Caichao, Frontiers of Agricultural Science and Engineering, 2016, 2, 341-346.

112. T. Pirzada, Z. Ashrafi, W. Xie and S. A. Khan, Adv. Funct. Mater., 2020, 30, 1907359.

113. X. Zhang, P. Liu, Y. Duan, M. Jiang and J. Zhang, RSC Adv., 2017, 7, 16467-16473.

114. H. Gu, X. Zhou, S. Lyu, D. Pan, M. Dong, S. Wu, T. Ding, X. Wei, I. Seok and S. Wei, J. Colloid Interface Sci., 2020, 560, 849-856.

115. D. Liu, Q. Wu, R. L. Andersson, M. S. Hedenqvist, S. Farris and R. T. Olsson, J. Mater. Chem. A, 2015, 3, 15745-15754.

116. S. Abd El-Nasser, S. Kim, H. Yoon, R. Toth, K. Pal and M. Bechelany, Organic Electronics, 2020, 76, 105443.

117. M. Jonoobi, J. Harun, A. P. Mathew and K. Oksman, Compos. Sci. Technol., 2010, 70, 1742-1747. 
118. J. Leitner, B. Hinterstoisser, M. Wastyn, J. Keckes and W. Gindl, Cellulose, 2007, 14, 419-425.

119. A. N. Nakagaito, S. Iwamoto and H. Yano, Appl. Phys. A, 2005, 80, 93-97.

120. N. Soykeabkaew, C. Sian, S. Gea, T. Nishino and T. Peijs, Cellulose, 2009, 16, 435-444.

121. M. H. Hussin, D. Trache, C. T. H. Chuin, M. R. N. Fazita, M. K. M. Haafiz and M. S. Hossain, in Sustainable Polymer Composites and Nanocomposites, Springer, 2019, pp. 653-691.

122. A. Dufresne, in Biomass Extrusion and Reaction Technologies: Principles to Practices and Future Potential, ACS Publications, 2018, pp. 137-152.

123. R. T. Olsson, M. A. S. A. Samir, G. Salazar-Alvarez, L. Belova, V. Ström, L. A. Berglund, O. Ikkala, J. Nogues and U. W. Gedde, Nat. Nanotechnol., 2010, 5, 584.

124. J.-M. Malho, P. i. Laaksonen, A. Walther, O. Ikkala and M. B. Linder, Biomacromolecules, 2012, 13, 1093-1099.

125. C.-N. Wu, T. Saito, S. Fujisawa, H. Fukuzumi and A. Isogai, Biomacromolecules, 2012, 13, 1927-1932.

126. R. Arvidsson, D. Nguyen and M. Svanström, Environ. Sci. Technol., 2015, 49, 6881-6890.

127. E. Robles, J. Fernández-Rodríguez, A. M. Barbosa, O. Gordobil, N. L. V. Carreño and J. Labidi, Carbohydr. Polym., 2018, 183, 294-302.

128. M. Pääkkö, M. Ankerfors, H. Kosonen, A. Nykänen, S. Ahola, M. Österberg, J. Ruokolainen, J. Laine, P. T. Larsson, O. Ikkala and T. Lindström, Biomacromolecules, 2007, 8, 1934-1941.

129. G. Siqueira, S. Tapin-Lingua, J. Bras, D. da Silva Perez and A. Dufresne, Cellulose, 2010, 17, 1147-1158.

130. T. Fattahi Meyabadi, F. Dadashian, G. Mir Mohamad Sadeghi and H. Ebrahimi Zanjani Asl, Powder Technol., 2014, 261, 232-240.

131. M. R. K. Sofla, R. J. Brown, T. Tsuzuki and T. J. Rainey, Adv. Nat. Sci.: Nanosci. Nanotechnol., 2016, 7, 035004.

132. S. Singh, K. K. Gaikwad, S.-I. Park and Y. S. Lee, Int. J. Biol. Macromol., 2017, 99, 506-510.

133. F. Beltramino, M. Blanca Roncero, T. Vidal and C. Valls, Carbohydr. Polym., 2018, 189, 39-47.

134. G. A. Siqueira, I. K. R. Dias and V. Arantes, Int. J. Biol. Macromol., 2019, 133, 1249-1259.

135. H. Tibolla, F. M. Pelissari, J. T. Martins, A. A. Vicente and F. C. Menegalli, Food Hydrocolloids, 2018, 75, 192-201.

136. R. Kumar, B. Rai and G. Kumar, Journal of Polymers and the Environment, 2019, 27, 2963-2973.

137. M. A. Yassin, A. A. M. Gad, A. F. Ghanem and M. H. Abdel Rehim, Carbohydrate Polymers, 2019, 205, 255-260.

138. P. Kumari, G. Pathak, R. Gupta, D. Sharma and A. Meena, DARU Journal of Pharmaceutical Sciences, 2019, 27, 683-693.

139. S. Wang, F. Jiang, X. Xu, Y. Kuang, K. Fu, E. Hitz and L. Hu, Adv. Mater., 2017, 29, 1702498.

140. M. Bakhshpour, E. Tamahkar, M. Andaç and A. Denizli, Colloids Surf., B, 2017, 158, 453-459.

141. S. Sheykhnazari, T. Tabarsa, A. Ashori, A. Shakeri and M. Golalipour, Carbohydr. Polym., 2011, 86, 1187-1191.

142. S. Ifuku, M. Nogi, K. Abe, K. Handa, F. Nakatsubo and H. Yano, Biomacromolecules, 2007, 8, 1973-1978.

143. N. S. Çetin, P. Tingaut, N. Özmen, N. Henry, D. Harper, M. Dadmun and G. Sèbe, Macromol. Biosci., 2009, 9, 997-1003.

144. R. Dash and A. J. Ragauskas, RSC Adv., 2012, 2, 3403-3409.

145. Y. Li and A. J. Ragauskas, RSC Adv., 2012, 2, 3347-3351.

146. E. Afra, H. Yousefi, M. M. Hadilam and T. Nishino, Carbohydr. Polym., 2013, 97, 725-730.

147. P. Phanthong, P. Reubroycharoen, X. Hao, G. Xu, A. Abudula and G. Guan, Carbon Resour. Convers., 2018, 1, 32-43.

148. X. Yang, N. Li, X. Lin, X. Pan and Y. Zhou, J. Agric. Food Chem., 2016, 64, 8379-8387.

149. K. Zhang, A. Barhoum, C. Xiaoqing, L. Haoyi and P. Samyn, 2019.

150. X. Chen, X. Cao, S. Sun, T. Yuan, S. Wang, Q. Shi and R. Sun, Sep. Purif. Technol., 2019, 209, 741-747.

151. G. Gellerstedt and G. Henriksson, in Monomers, polymers and composites from renewable resources, Elsevier, 2008, pp. 201-224.

152. W. He, W. Gao and P. Fatehi, ACS Sustainable Chem. Eng., 2017, 5, 10597-10605. 
153. A. Yuliestyan, M. Garcia-Morales, E. Moreno, V. Carrera and P. Partal, Mater. Des., 2017, 131, 242251.

154. F. Peng, P. Peng, F. Xu and R.-C. Sun, Biotechnol. Adv., 2012, 30, 879-903.

155. L. Pranger and R. Tannenbaum, Macromolecules, 2008, 41, 8682-8687.

156. D. Klemm, B. Heublein, H. P. Fink and A. Bohn, Angew. Chem., Int. Ed., 2005, 44, 3358-3393.

157. G. Thoorens, F. Krier, B. Leclercq, B. Carlin and B. Evrard, Int. J. Pharm., 2014, 473, 64-72.

158. P. Stenius, S. P.-I. Yhdistys, T. Press and F. Oy, Forest products chemistry, Fapet Oy, 2000.

159. H. Wang, G. Gurau and R. D. Rogers, Chem. Soc. Rev., 2012, 41, 1519-1537.

160. W. Chen, H. Yu, Y. Liu, P. Chen, M. Zhang and Y. Hai, Carbohydr. Polym., 2011, 83, 1804-1811.

161. M. Ul-Islam, S. Khan, W. A. Khattak, M. W. Ullah and J. K. Park, in Eco-friendly Polymer Nanocomposites, Springer, 2015, pp. 399-437.

162. K. Ji, W. Wang, B. Zeng, S. Chen, Q. Zhao, Y. Chen, G. Li and T. Ma, Sci. Rep., 2016, 6, 1-12.

163. P. A. Rühs, F. Storz, Y. A. L. Gómez, M. Haug and P. Fischer, npj Biofilms Microbiomes, 2018, 4, 1-6.

164. P. Jacek, F. Dourado, M. Gama and S. Bielecki, Microb. Biotechnol., 2019, 12, 633-649.

165. A. Barhoum, H. Rahier, R. E. Abou-Zaied, M. Rehan, T. Dufour, G. Hill and A. Dufresne, ACS Appl. Mater. Interfaces, 2014, 6, 2734-2744.

166. M. Thébault, A. Pizzi, H. A. Essawy, A. Barhoum and G. Van Assche, Eur. Polym. J., 2015, 67, 513-526.

167. P. Samyn, A. Barhoum, T. Öhlund and A. Dufresne, J. Mater. Sci., 2018, 53, 146-184.

168. A. Barhoum, L. Van Lokeren, H. Rahier, A. Dufresne and G. Van Assche, J. Mater. Sci., 2015, 50, 79087918.

169. R. Rasouli, A. Barhoum and H. Uludag, Biomater. Sci., 2018, 6, 1312-1338.

170. F. A. Morsy, S. M. El-Sheikh and A. Barhoum, Arabian J. Chem., 2019, 12, 1186-1196.

171. S. Hammani, A. Barhoum and M. Bechelany, J. Mater. Sci., 2018, 53, 1911-1921.

172. A. García, A. Gandini, J. Labidi, N. Belgacem and J. Bras, Ind. Crops Prod., 2016, 93, 26-38.

173. K. Missoum, N. M. Belgacem and J. Bras, Materials, 2013, 6.

174. M. Smyth, C. Fournier, C. Driemeier, C. Picart, E. J. Foster and J. Bras, Biomacromolecules, 2017, 18, 2034-2044.

175. M. F. Rosa, E. S. Medeiros, J. A. Malmonge, K. S. Gregorski, D. F. Wood, L. H. C. Mattoso, G. Glenn, W. J. Orts and S. H. Imam, Carbohydr. Polym., 2010, 81, 83-92.

176. A. F. Jozala, L. C. de Lencastre-Novaes, A. M. Lopes, V. de Carvalho Santos-Ebinuma, P. G. Mazzola, A. Pessoa-Jr, D. Grotto, M. Gerenutti and M. V. Chaud, Appl. Microbiol. Biotechnol., 2016, 100, 20632072.

177. R. K. Mishra, A. Sabu and S. K. Tiwari, J. Saudi Chem. Soc., 2018, 22, 949-978.

178. G. Zheng, Y. Cui, E. Karabulut, L. Wågberg, H. Zhu and L. Hu, MRS Bull., 2013, 38, 320-325.

179. D. Gao, Y. Luan, Q. Wang, Q. Liang and Q. Qi, Microb. Cell Fact., 2015, 14, 159.

180. F. Li, P. Biagioni, M. Bollani, A. Maccagnan and L. Piergiovanni, Cellulose, 2013, 20, 2491-2504.

181. J. Araki, M. Wada, S. Kuga and T. Okano, Colloids Surf., A, 1998, 142, 75-82.

182. J. Araki, M. Wada, S. Kuga and T. Okano, Langmuir, 2000, 16, 2413-2415.

183. N. Valera, D. Chaussy and R. Passas, Cellul. Chem. Technol., 2004, 38, 245-254.

184. A. P. Mathew, K. Oksman and M. Sain, J. Appl. Polym. Sci., 2005, 97, 2014-2025.

185. R. Barati and J. T. Liang, J. Appl. Polym. Sci., 2014, 131.

186. T. Maneerung, S. Tokura and R. Rujiravanit, Carbohydr. Polym., 2008, 72, 43-51.

187. C. G. Otoni, P. J. P. Espitia, R. J. Avena-Bustillos and T. H. McHugh, Food Res. Int., 2016, 83, 60-73.

188. S. Yadav, M. P. Illa, T. Rastogi and C. S. Sharma, Appl. Mater. Today, 2016, 4, 62-70.

189. N. Dhar, 2010.

190. N. Shah, M. UI-Islam, W. A. Khattak and J. K. Park, Carbohydr. Polym., 2013, 98, 1585-1598.

191. Y. Xue, Z. Mou and H. Xiao, Nanoscale, 2017, 9, 14758-14781.

192. D. V. Mashego, 2016.

193. A. Dufresne, Current Forestry Reports, 2019, 5, 76-89.

194. T. Paulraj, A. V. Riazanova and A. J. Svagan, Acta biomaterialia, 2018, 69, 196-205.

195. M. M. Chang, T. Song, X. X. Liu, Q. X. Lin, B. He and J. L. Ren, Current Medicinal Chemistry, 2020. 
196. C. Endes, S. Camarero-Espinosa, S. Mueller, E. J. Foster, A. Petri-Fink, B. Rothen-Rutishauser, C. Weder and M. J. D. Clift, Journal of nanobiotechnology, 2016, 14, 78.

197. Y. Shan, H. Wu, H. Xiao, L. Chen and L. Huang, Chemistry and Industry of Forest Products, 2019, 39, 115-120.

198. J. Liu, F. Cheng, H. Grénman, S. Spoljaric, J. Seppälä, J. E. Eriksson, S. Willför and C. Xu, Carbohydr. Polym., 2016, 148, 259-271.

199. Z. Tehrani, H. R. Nordli, B. Pukstad, D. T. Gethin and G. Chinga-Carrasco, Ind. Crops Prod., 2016, 93, 193-202.

200. J. Rojas, M. Bedoya and Y. Ciro, Cellulose-Fundamental Aspects and Current Trends; Intech: Vigo, Spain, 2015, 8, 193-228.

201. N. Lin and A. Dufresne, Eur. Polym. J., 2014, 59, 302-325.

202. R. Rasouli, A. Barhoum, M. Bechelany and A. Dufresne, Macromol. Biosci., 2019, 19, 1800256.

203. N. Halib, F. Perrone, M. Cemazar, B. Dapas, R. Farra, M. Abrami, G. Chiarappa, G. Forte, F. Zanconati, G. Pozzato, L. Murena, N. Fiotti, R. Lapasin, L. Cansolino, G. Grassi and M. Grassi, Materials, 2017, 10.

204. G. F. Picheth, C. L. Pirich, M. R. Sierakowski, M. A. Woehl, C. N. Sakakibara, C. F. de Souza, A. A. Martin, R. da Silva and R. A. de Freitas, Int. J. Biol. Macromol., 2017, 104, 97-106.

205. K. Tan, S. Heo, M. Foo, I. M. Chew and C. Yoo, Sci. Total Environ., 2019, 650, 1309-1326.

206. S. F. Jin, Y. Chen and M. Liu, Adv. Mater. Res., 2013, 662, 198-201.

207. L. Song, K. Takahashi, Y. Ito and T. Aita, Microsystem Technologies, 2018, 1-11.

208. H. Golmohammadi, E. Morales-Narvaez, T. Naghdi and A. Merkoci, Chem. Mater., 2017, 29, 54265446.

209. H. Wei, K. Rodriguez, S. Renneckar and P. J. Vikesland, Environ. Sci.: Nano, 2014, 1, 302-316.

210. M. Rehan, A. Barhoum, T. A. Khattab, L. Gätjen and R. Wilken, Cellulose, 2019, 26, 5437-5453.

211. X. Chen, L. Cheng, H. Li, A. Barhoum, Y. Zhang, X. He, W. Yang, M. M. Bubakir and H. Chen, ChemistrySelect, 2018, 3, 9127-9143.

212. M. L. Soriano and C. Ruiz-Palomero, Nanotechnol. Environ. Sci., 2018, 579-598.

213. N. Mahfoudhi and S. Boufi, Cellulose, 2017, 24, 1171-1197.

214. F. Piccinno, R. Hischier, S. Seeger and C. Som, Journal of Cleaner Production, 2018, 174, 283-295.

215. N. Mohammed, N. Grishkewich and K. C. Tam, Environ. Sci.: Nano, 2018, 5, 623-658.

216. W. Chen, H. Yu, S.-Y. Lee, T. Wei, J. Li and Z. Fan, Chem. Soc. Rev., 2018, 47, 2837-2872.

217. M. Falk and S. Shleev, Biosensors and Bioelectronics, 2019, 126, 275-291.

218. J.-H. Kim, D. Lee, Y.-H. Lee, W. Chen and S.-Y. Lee, Adv. Mater., 2019, 31, 1804826.

219. X. Du, Z. Zhang, W. Liu and Y. Deng, Nano Energy, 2017, 35, 299-320.

220. C. Chen and L. Hu, Acc. Chem. Res., 2018, 51, 3154-3165.

221. K.-H. Choi, S.-J. Cho, S.-J. Chun, J. T. Yoo, C. K. Lee, W. Kim, Q. Wu, S.-B. Park, D.-H. Choi, S.-Y. Lee and S.-Y. Lee, Nano Letters, 2014, 14, 5677-5686.

222. J. Cai, S. Liu, J. Feng, S. Kimura, M. Wada, S. Kuga and L. Zhang, Angew. Chem., Int. Ed., 2012, 51, 20762079.

223. X. Yang, K. Shi, I. Zhitomirsky and E. D. Cranston, Adv. Mater., 2015, 27, 6104-6109.

224. W. Zhang, Y. Zhang, C. Lu and Y. Deng, J. Mater. Chem., 2012, 22, 11642-11650.

225. X. Zhang, Z. Lin, B. Chen, W. Zhang, S. Sharma, W. Gu and Y. Deng, J. Power Sources, 2014, 246, 283289.

226. L. Dai, D. W. Chang, J.-B. Baek and W. Lu, Small, 2012, 8, 1130-1166.

227. J. Jose, V. Thomas, V. Vinod, R. Abraham and S. Abraham, Journal of Science: Advanced Materials and Devices, 2019, 4, 333-340.

228. S. Liu, Y. Zheng, Y. Sun, L. Su, L. Yue, Y. Wang, J. Feng and J. Fan, RSC Adv., 2016, 6, 112971-112980.

229. G. Jiang, J. Qiao and F. Hong, Int. J. Hydrogen Energy, 2012, 37, 9182-9192.

230. C. W. Lin, S. S. Liang, S. W. Chen and J. T. Lai, J. Power Sources, 2013, 232, 297-305.

231. T. Bayer, B. V. Cunning, R. Selyanchyn, M. Nishihara, S. Fujikawa, K. Sasaki and S. M. Lyth, Chem. Mater., 2016, 28, 4805-4814. 
232. L. Hu, G. Zheng, J. Yao, N. Liu, B. Weil, M. Eskilsson, E. Karabulut, Z. Ruan, S. Fan, J. T. Bloking, M. D. McGehee, L. Wågberg and Y. Cui, Energy Environ. Sci., 2013, 6, 513-518.

233. K. Miettunen, J. Vapaavuori, A. Tiihonen, A. Poskela, P. Lahtinen, J. Halme and P. Lund, Nano Energy, 2014, 8, 95-102.

234. S. V. Costa, P. Pingel, S. Janietz and A. F. Nogueira, J. Appl. Polym. Sci., 2016, 133.

235. L. Gao, L. Chao, M. Hou, J. Liang, Y. Chen, H.-D. Yu and W. Huang, npj Flexible Electron., 2019, 3, 1-8.

236. L. Gao, L. Chao, M. Hou, J. Liang, Y. Chen, H.-D. Yu and W. Huang, npj Flexible Electron., $2019,3,4$.

237. C. Campano, N. Merayo, A. Balea, Q. Tarrés, M. Delgado-Aguilar, P. Mutjé, C. Negro and Á. Blanco, Cellulose, 2018, 25, 269-280.

238. M. A. Hubbe and P. Pruszynski, BioResources, 2020, 15, 1978-2004.

239. A. F. Lourenço, J. A. F. Gamelas, P. Sarmento and P. J. T. Ferreira, Cellulose, 2020, 1-13.

240. R. Koppolu, T. Abitbol, V. Kumar, A. K. Jaiswal, A. Swerin and M. Toivakka, Cellulose, 2018, 25, 60556069.

241. T. Moberg, K. Sahlin, K. Yao, S. Geng, G. Westman, Q. Zhou, K. Oksman and M. Rigdahl, Cellulose, 2017, 24, 2499-2510.

242. P. Tyagi, L. A. Lucia, M. A. Hubbe and L. Pal, Carbohydr. Polym., 2019, 206, 281-288.

243. J. Guo, W. Fang, A. Welle, W. Feng, I. Filpponen, O. J. Rojas and P. A. Levkin, ACS Appl. Mater. Interfaces, 2016, 8, 34115-34122.

244. E. C. Lengowski, E. A. B. Júnior, M. M. N. Kumode, M. E. Carneiro and K. G. Satyanarayana, in Sustainable Polymer Composites and Nanocomposites, Springer, 2019, pp. 1001-1025.

245. K. Yao, S. Huang, H. Tang, Y. Xu, G. Buntkowsky, L. A. Berglund and Q. Zhou, ACS Appl. Mater. Interfaces, 2017, 9, 20169-20178.

246. C. Gómez H, A. Serpa, J. Velásquez-Cock, P. Gañán, C. Castro, L. Vélez and R. Zuluaga, Food Hydrocolloids, 2016, 57, 178-186.

247. L. Golchoobi, M. Alimi, S. Shokoohi and H. Yousefi, J. Texture Stud., 2016, 47, 403-412.

248. M. L. Corral, P. Cerrutti, A. Vázquez and A. Califano, Food Hydrocolloids, 2017, 67, 189-196.

249. F. Keivani Nahr, R. R. Mokarram, M. A. Hejazi, B. Ghanbarzadeh, M. Sowti Khiyabani and K. Zoroufchi Benis, LWT--Food Sci. Technol., 2015, 64, 326-332.

250. Y. Xiao, Y. Liu, Y. Wang, Y. Jin, X. Guo, Y. Liu, X. Qi, H. Lei and H. Xu, Carbohydr. Polym., 2020, 231, 115749.

251. G. M. DeLoid, X. Cao, R. M. Molina, D. I. Silva, K. Bhattacharya, K. W. Ng, S. C. J. Loo, J. D. Brain and P. Demokritou, Environ. Sci.: Nano, 2019, 6, 2105-2115.

252. H. M. C. Azeredo, M. F. Rosa and L. H. C. Mattoso, Ind. Crops Prod., 2017, 97, 664-671.

253. K. V. Rastogi and P. Samyn, Coatings, 2015, 5.

254. O. M. Terrett and P. Dupree, Curr. Opin. Biotechnol., 2019, 56, 97-104.

255. H.-D. Yoo, D. Kim and S.-H. Paek, Biomol. Ther., 2012, 20, 371.

256. A. K. Chandel, F. A. F. Antunes, R. Terán-Hilares, J. Cota, S. Ellilä, M. H. L. Silveira, J. C. dos Santos and S. S. da Silva, in Advances in Sugarcane Biorefinery, Elsevier, 2018, pp. 97-134.

257. M. H. Ramage, H. Burridge, M. Busse-Wicher, G. Fereday, T. Reynolds, D. U. Shah, G. Wu, L. Yu, P. Fleming, D. Densley-Tingley, J. Allwood, P. Dupree, P. F. Linden and O. Scherman, Renewable Sustainable Energy Rev., 2017, 68, 333-359.

258. V. B. Agbor, N. Cicek, R. Sparling, A. Berlin and D. B. Levin, Biotechnol. Adv., 2011, 29, 675-685.

259. H. V. Scheller and P. Ulvskov, Annu. Rev. Plant Biol., 2010, 61, 263-289.

260. E. Sjöström and R. Alén, Analytical methods in wood chemistry, pulping, and papermaking, Springer Science \& Business Media, 2013.

261. Q. Luo, H. Peng, M. Zhou, D. Lin, R. Ruan, Y. Wan, J. Zhang and Y. Liu, BioResources, 2012.

262. A. Gandini, Green Chem., 2011, 13, 1061-1083.

263. A. Avanthi, S. Kumar, K. C. Sherpa and R. Banerjee, Biofuels, 2017, 8, 431-444.

264. I. Spiridon and V. I. Popa, Polysaccharides: structural diversity and functional versatility, 2005, 2.

265. T. R. Cipriani, C. G. Mellinger, L. M. de Souza, C. H. Baggio, C. S. Freitas, M. C. A. Marques, P. A. J. Gorin, G. L. Sassaki and M. lacomini, J. Nat. Prod., 2006, 69, 1018-1021. 
266. A. Kardošová, A. Malovíková, V. Pätoprstý, G. Nosál'ová and T. Matáková, Carbohydr. Polym., 2002, 47, 27-33.

267. W.-M. Kulicke, A. I. Lettau and H. Thielking, Carbohydr. Res., 1997, 297, 135-143.

268. S. Kitamura, T. Hori, K. Kurita, K. Takeo, C. Hara, W. Itoh, K. Tabata, A. Elgsaeter and B. T. Stokke, Carbohydr. Res., 1994, 263, 111-121.

269. S. Daus and T. Heinze, Macromolecular Bioscience, 2010, 10, 211-220.

270. X. Lin, J. Zhao, M. Wu, S. Kuga, Y. Huang and E. Contributed, Res. Rev. J. Microbiol. Biotechnol, 2016, 5, 14-18.

271. P. Ghofrani-Isfahani, H. Baniamerian, P. Tsapekos, M. Alvarado-Morales, T. Kasama, M. Shahrokhi, M. Vossoughi and I. Angelidaki, Energy, 2019, 116580.

272. R. F. Perez, O. S. G. P. Soares, A. M. D. de Farias, M. F. R. Pereira and M. A. Fraga, Appl. Catal., B, 2018, 232, 101-107.

273. A. A. Oun, S. Shankar and J.-W. Rhim, Crit. Rev. Food Sci. Nutr., 2020, 60, 435-460.

274. R. B. Garcia, T. Nagashima Jr, A. K. C. Praxedes, F. N. Raffin, T. F. A. L. Moura and E. S. T. do Egito, Polym. Bull., 2001, 46, 371-379.

275. Y. Habibi and L. A. Lucia, Polysaccharide building blocks: a sustainable approach to the development of renewable biomaterials, John Wiley \& Sons, 2012.

276. F. Li, S. Ren, W. Zhang, Z. Xu, G. Xie, Y. Chen, Y. Tu, Q. Li, S. Zhou, Y. Li, F. Tu, L. Liu, Y. Wang, J. Jiang, J. Qin, S. Li, Q. Li, H.-C. Jing, F. Zhou, N. Gutterson and L. Peng, Bioresour. Technol., 2013, 130, 629-637.

277. P. Hong, Y. Liu, W. Peng, J. Zhang and R. Ruan, BioResources, 2015.

278. X. Lin, J. Wang, X. Han, M. Wu, S. Kuga and Y. Huang, Journal of Bioresources and Bioproducts, 2017, 2, 149-152.

279. W. Chen, L.-x. Zhong, X.-w. Peng, K. Wang, Z.-f. Chen and R.-c. Sun, Catal. Sci. Technol., 2014, 4, 14261435.

280. W. Zhao, K. Odelius, U. Edlund, C. Zhao and A.-C. Albertsson, Biomacromolecules, 2015, 16, 2522-2528.

281. B. L. Peng, N. Dhar, H. L. Liu and K. C. Tam, Can. J. Chem. Eng., 2011, 89, 1191-1206.

282. Y. Guan, B. Zhang, J. Bian, F. Peng and R.-C. Sun, Cellulose, 2014, 21, 1709-1721.

283. G.-G. Chen, X.-M. Qi, Y. Guan, F. Peng, C.-L. Yao and R.-C. Sun, ACS Sustainable Chem. Eng., 2016, 4, 1985-1993.

284. W. Kong, D. Huang, G. Xu, J. Ren, C. Liu, L. Zhao and R. Sun, Chemistry-An Asian Journal, 2016, 11, 1697-1704.

285. J. Yu, Y. Zhu, H. Ma, L. Liu, Y. Hu, J. Xu, Z. Wang and Y. Fan, Cellulose, 2019, 26, 6023-6034.

286. Y. Pei, Y. Li, Y. Zhang, C. Yu, T. Fu, J. Zou, Y. Tu, L. Peng and P. Chen, Bioresour. Technol., 2016, 203, 325-333.

287. Y. Jiang, T. Chen, W. Dong, M. Zhang, W. Zhang, H. Wu, J. Ma, M. Jiang and F. Xin, Curr. Microbiol., 2018, 75, 305-308.

288. F. Du, L. Zhang, J. Ma and X. Peng, Carbohydrate Polymers, 2019, 217, 224-231.

289. K. M. Haafiz, O. F. A. Taiwo, N. Razak, H. Rokiah, H. M. Hazwan, N. F. M. Rawi and H. P. S. A. Khalil, BioResources, 2019, 14, 8029-8047.

290. H. Peng, A. Yang and J. Xiong, Carbohydr. Polym., 2013, 91, 348-355.

291. S. Daus and T. Heinze, Macromol. Biosci., 2010, 10, 211-220.

292. X.-w. Peng, J.-I. Ren, L.-x. Zhong and R.-c. Sun, Biomacromolecules, 2011, 12, 3321-3329.

293. X.-W. Peng, J.-L. Ren, L.-X. Zhong, X.-F. Cao and R.-C. Sun, J. Agric. Food Chem., 2011, 59, 570-576.

294. W. Kong, D. Huang, G. Xu, J. Ren, C. Liu, L. Zhao and R. Sun, Chem. Asian J., 2016, 11, 1697-1704.

295. X. Lin, M. Wu, S. Kuga, T. Endo and Y. Huang, Polym. J., 2016, 48, 919-923.

296. G.-Q. Fu, L.-Y. Su, P.-P. Yue, Y.-H. Huang, J. Bian, M.-F. Li, F. Peng and R.-C. Sun, Cellulose, 2019, 26, 7195-7206.

297. N. M. Aguilar, F. Arteaga-Cardona, J. O. Estévez, N. R. Silva-González, J. C. Benítez-Serrano and U. Salazar-Kuri, J. Environ. Chem. Eng., 2018, 6, 6275-6281.

298. C. Gao, J. Ren, C. Zhao, W. Kong, Q. Dai, Q. Chen, C. Liu and R. Sun, Carbohydr. Polym., 2016, 151, 189197. 
299. X.-F. Sun, H.-h. Wang, Z.-x. Jing and R. Mohanathas, Carbohydr. Polym., 2013, 92, 1357-1366.

300. J. Liu, G. Chinga-Carrasco, F. Cheng, W. Xu, S. Willför, K. Syverud and C. Xu, Cellulose, 2016, 23, 31293143.

301. W. Farhat, R. Venditti, N. Mignard, M. Taha, F. Becquart and A. Ayoub, Int. J. Biol. Macromol., 2017, 104, 564-575.

302. P. Yang, Z. Zhu, M. Chen, W. Chen and X. Zhou, Opt. Mater., 2018, 85, 329-336.

303. Y. Lian, J. Zhang, N. Li and Q. Ping, BioResources, 2018, 13, 3208-3218.

304. X. Dou, I. Hasa, M. Hekmatfar, T. Diemant, R. J. Behm, D. Buchholz and S. Passerini, ChemSusChem, 2017, 10, 2668-2676.

305. J. Revathi, A. Jyothirmayi, T. N. Rao and A. S. Deshpande, Global Challenges, 2020, 4, 1900048.

306. C. Falco, J. M. Sieben, N. Brun, M. Sevilla, T. van der Mauelen, E. Morallón, D. Cazorla-Amorós and M.M. Titirici, ChemSusChem, 2013, 6, 374-382.

307. H. Wang, Z. Li and D. Mitlin, ChemElectroChem, 2014, 1, 332-337.

308. H. C. Bongao, R. R. A. Gabatino, C. F. H. Arias and E. R. Magdaluyo Jr, Mater. Today: Proc., 2020, 22, 275-280.

309. F. Tatar, M. T. Tunç, M. Dervisoglu, D. Cekmecelioglu and T. Kahyaoglu, Food Res. Int., 2014, 57, 168175.

310. L. R. Mugwagwa and A. F. A. Chimphango, Food Packag. Shelf Life, 2020, 24, 100481.

311. P. Peng and D. She, Carbohydr. Polym., 2014, 112, 701-720.

312. J. Liu, S. Willför and C. Xu, Bioact. Carbohydr. Diet. Fibre, 2015, 5, 31-61.

313. J. Wen, J. Yang, W. Wang, M. Li, F. Peng, J. Bian and R. Sun, International Journal of Biological Macromolecules, 2019, DOI: https://doi.org/10.1016/j.ijbiomac.2019.11.035.

314. M. Shivakumar, K. L. Nagashree, S. Yallappa, S. Manjappa, K. S. Manjunath and M. S. Dharmaprakash, Enzyme and Microbial Technology, 2017, 97, 55-62.

315. J. Ma, D. Li, L. Zhong, F. Du, J. Tan, J. Yang and X. Peng, Carbohydrate polymers, 2018, 199, 382-389.

316. J. Athinarayanan, V. S. Periasamy, M. Alhazmi, K. A. Alatiah and A. A. Alshatwi, Ceramics international, 2015, 41, 275-281.

317. W. Zhao, R. W. N. Nugroho, K. Odelius, U. Edlund, C. Zhao and A.-C. Albertsson, ACS Appl. Mater. Interfaces, 2015, 7, 4202-4215.

318. B. Balli, M. H. Calimli, E. Kuyuldar and F. Sen, in Sustainable Polymer Composites and Nanocomposites, eds. Inamuddin, S. Thomas, R. Kumar Mishra and A. M. Asiri, Springer International Publishing, Cham, 2019, DOI: 10.1007/978-3-030-05399-4_10, pp. 293-311.

319. K. S. Mikkonen and M. Tenkanen, Trends in Food Science \& Technology, 2012, 28, 90-102.

320. J. Kochumalayil Jose, 2012.

321. J. Hartman, A. C. Albertsson, M. S. Lindblad and J. Sjöberg, Journal of Applied Polymer Science, 2006, 100, 2985-2991.

322. M. Gröndahl, L. Eriksson and P. Gatenholm, Biomacromolecules, 2004, 5, 1528-1535.

323. Y. Guan, B. Zhang, X. Tan, X.-M. Qi, J. Bian, F. Peng and R.-C. Sun, ACS Sustainable Chemistry \& Engineering, 2014, 2, 1811-1818.

324. I. S. Bayer, S. Guzman-Puyol, J. A. Heredia-Guerrero, L. Ceseracciu, F. Pignatelli, R. Ruffilli, R. Cingolani and A. Athanassiou, Macromolecules, 2014, 47, 5135-5143.

325. H. M. Anawar and V. Strezov, in Emerging and Nanomaterial Contaminants in Wastewater, eds. A. K. Mishra, H. M. D. Anawar and N. Drouiche, Elsevier, 2019, DOI: https://doi.org/10.1016/B978-0-12814673-6.00004-8, pp. 83-104.

326. C. Irawan, I. F. Nata, M. D. Putra, M. Elma and K. F. Hanisa, Biocomposite Materials of Eleocharis dulcis Fibers with Iron (III) Nanoparticles and Its Potential for Sasirangan Textile Wastewater Treatment, 2017.

327. S. Beisl, P. Loidolt, A. Miltner and A. Friedl, Chem. Eng. Trans., 2018, 70, 331-336.

328. D. Son, S. Gu, J.-W. Choi, D. J. Suh, J. Jae, J. Choi and J.-M. Ha, J. Ind. Eng. Chem., 2019, 69, 304-314.

329. S. Beisl, A. Friedl and A. Miltner, Int. J. Mol. Sci., 2017, 18, 2367.

330. S. Beisl, A. Miltner and A. Friedl, Int. J. Mol. Sci., 2017, 18. 
331. R. Vanholme, B. Demedts, K. Morreel, J. Ralph and W. Boerjan, Plant physiology, 2010, 153, 895-905.

332. P. Gonugunta, S. Vivekanandhan, A. K. Mohanty and M. Misra, World Journal of Nano Science and Engineering, 2012, 2, 148-153.

333. G. Gellerstedt and G. Henriksson, in Monomers, Polymers and Composites from Renewable Resources, eds. M. N. Belgacem and A. Gandini, Elsevier, Amsterdam, 2008, DOI: https://doi.org/10.1016/B9780-08-045316-3.00009-0, pp. 201-224.

334. A. G. Vishtal and A. Kraslawski, BioResources, 2011.

335. H. Sixta and G. Schild, Lenzinger Berichte, 2009, 87, 26-37.

336. H. Chung and N. R. Washburn, in Lignin in Polymer Composites, eds. O. Faruk and M. Sain, William Andrew Publishing, 2016, DOI: https://doi.org/10.1016/B978-0-323-35565-0.00002-3, pp. 13-25.

337. B. Saake and R. Lehnen, Journal, 2007.

338. A. G. Vishtal and A. Kraslawski, BioResources, 2011, 6, 3547-3568.

339. J. Domínguez-Robles, T. Tamminen, T. Liitiä, M. S. Peresin, A. Rodríguez and A.-S. Jääskeläinen, International journal of biological macromolecules, 2018, 106, 979-987.

340. P. R. Jiangxi, Functional Materials from Lignin: Methods and Advances, 2018, 3, 29.

341. T. Auxenfans, D. Crônier, B. Chabbert and G. Paës, Biotechnology for biofuels, 2017, 10, 36.

342. A. Jensen, Y. Cabrera, C.-W. Hsieh, J. Nielsen, J. Ralph and C. Felby, Holzforschung, 2017, 71, 461-469.

343. A. Stücker, F. Schütt, B. Saake and R. Lehnen, Industrial Crops and Products, 2016, 85, 300-308.

344. A. C. dos Santos, E. Ximenes, Y. Kim and M. R. Ladisch, Trends in Biotechnology, 2019, 37, 518-531.

345. W. O. S. Doherty, P. Mousavioun and C. M. Fellows, Ind. Crops Prod., 2011, 33, 259-276.

346. S. Beisl, A. Miltner and A. Friedl, Int. J. Mol. Sci., 2017, 18, 1244.

347. F. R. Wurm and C. K. Weiss, Front. Chem., 2014, 2.

348. I. A. Gilca, V. I. Popa and C. Crestini, Ultrason. Sonochem., 2015, 23, 369-375.

349. A. P. Richter, B. Bharti, H. B. Armstrong, J. S. Brown, D. Plemmons, V. N. Paunov, S. D. Stoyanov and O. D. Velev, Langmuir, 2016, 32, 6468-6477.

350. P. Figueiredo, K. Lintinen, A. Kiriazis, V. Hynninen, Z. Liu, T. Bauleth-Ramos, A. Rahikkala, A. Correia, T. Kohout, B. Sarmento, J. Yli-Kauhaluoma, J. Hirvonen, O. Ikkala, M. A. Kostiainen and H. A. Santos, Biomaterials, 2017, 121, 97-108.

351. K. Lintinen, M. Latikka, M. H. Sipponen, R. H. A. Ras, M. Österberg and M. A. Kostiainen, RSC Adv., 2016, 6, 31790-31796.

352. M. B. Agustin, P. A. Penttilä, M. Lahtinen and K. S. Mikkonen, ACS Sustainable Chemistry \& Engineering, 2019, 7, 19925-19934.

353. M. H. Sipponen, H. Lange, C. Crestini, A. Henn and M. Österberg, ChemSusChem, 2019, 12, 2039-2054.

354. H. Setälä, H.-L. Alakomi, A. Paananen, G. R. Szilvay, M. Kellock, M. Lievonen, V. Liljeström, E.-L. Hult, K. Lintinen, M. Österberg and M. Kostiainen, Cellulose, 2020, 27, 273-284.

355. W. Yang, E. Fortunati, D. Gao, G. M. Balestra, G. Giovanale, X. He, L. Torre, J. M. Kenny and D. Puglia, ACS Sustainable Chemistry \& Engineering, 2018, 6, 3502-3514.

356. S. R. Yearla and K. Padmasree, J. Exp. Nanosci., 2016, 11, 289-302.

357. P. Figueiredo, C. Ferro, M. Kemell, Z. Liu, A. Kiriazis, K. Lintinen, H. F. Florindo, J. Yli-Kauhaluoma, J. Hirvonen, M. A. Kostiainen and H. A. Santos, Nanomedicine, 2017, 12, 2581-2596.

358. S. Iravani and R. S. Varma, Green Chem., 2020, 22, 612-636.

359. O. ur Rahman, S. Shi, J. Ding, D. Wang, S. Ahmad and H. Yu, New J. Chem., 2018, 42, 3415-3425.

360. L. Chen, X. Zhou, Y. Shi, B. Gao, J. Wu, T. B. Kirk, J. Xu and W. Xue, Chem. Eng. J., 2018, 346, 217-225.

361. X. Zhang, M. Yang, Q. Yuan and G. Cheng, ACS Sustainable Chem. Eng., 2019, 7, 17166-17174.

362. A. A. Myint, H. W. Lee, B. Seo, W.-S. Son, J. Yoon, T. J. Yoon, H. J. Park, J. Yu, J. Yoon and Y.-W. Lee, Green Chem., 2016, 18, 2129-2146.

363. M. Lievonen, J. J. Valle-Delgado, M.-L. Mattinen, E.-L. Hult, K. Lintinen, M. A. Kostiainen, A. Paananen, G. R. Szilvay, H. Setälä and M. Österberg, Green Chem., 2016, 18, 1416-1422.

364. M. Si, J. Zhang, Y. He, Z. Yang, X. Yan, M. Liu, S. Zhuo, S. Wang, X. Min and C. Gao, Green Chem., 2018, 20, 3414-3419. 
365. Y. Liu, J. Zheng, J. Xiao, X. He, K. Zhang, S. Yuan, Z. Peng, Z. Chen and X. Lin, ACS omega, 2019, 4, 1982919839.

366. H. Sadeghifar, R. A. Venditti, J. Pawlak and J. Jur, BioResources, 2019, 14, 6179-6185.

367. S.-M. Li, S.-L. Sun, M.-G. Ma, Y.-Y. Dong, L.-H. Fu, R.-C. Sun and F. Xu, BioResources, 2013.

368. M. Lallave, J. Bedia, R. Ruiz-Rosas, J. Rodríguez-Mirasol, T. Cordero, J. C. Otero, M. Marquez, A. Barrero and I. G. Loscertales, Adv. Mater., 2007, 19, 4292-4296.

369. M.-G. Ma, J.-F. Zhu, R.-C. Sun and Y.-J. Zhu, Mater. Lett., 2009, 63, 2513-2515.

370. Z. Zeng, C. Wang, Y. Zhang, P. Wang, S. I. Seyed Shahabadi, Y. Pei, M. Chen and X. Lu, ACS Applied Materials \& Interfaces, 2018, 10, 8205-8213.

371. H. Wang, X. Qiu, R. Zhong, F. Fu, Y. Qian and D. Yang, Materials Chemistry and Physics, 2017, 199, 193202.

372. E.-S. Lee, Y.-O. Kim, Y.-M. Ha, D. Lim, J. Y. Hwang, J. Kim, M. Park, J. W. Cho and Y. C. Jung, European Polymer Journal, 2018, 105, 79-84.

373. S. Laurichesse and L. Avérous, Prog. Polym. Sci., 2014, 39, 1266-1290.

374. D. Tian, J. Hu, J. Bao, R. P. Chandra, J. N. Saddler and C. Lu, Biotechnology for biofuels, 2017, 10, 192.

375. Y. Ma, L. Lv, Y. Guo, Y. Fu, Q. Shao, T. Wu, S. Guo, K. Sun, X. Guo and E. K. Wujcik, Polymer, 2017, 128, $12-23$.

376. S. Thakur, P. P. Govender, M. A. Mamo, S. Tamulevicius, Y. K. Mishra and V. K. Thakur, Vacuum, 2017, 146, 342-355.

377. S. Wang, N. Feng, J. Zheng, K. B. Yoon, D. Lee, M. Qu, X. Zhang and H. Zhang, Polymers for Advanced Technologies, 2016, 27, 1351-1354.

378. S. I. Seyed Shahabadi, J. Kong and X. Lu, ACS Sustainable Chemistry \& Engineering, 2017, 5, 3148-3157.

379. S. Sohni, R. Hashim, H. Nidaullah, J. Lamaming and O. Sulaiman, Int. J. Biol. Macromol., 2019, 132, $1304-1317$.

380. W. Xiong, D. Yang, M. A. Alam, J. Xu, Y. Li, H. Wang and X. Qiu, Industrial Crops and Products, 2020, 144, 112039.

381. F. Xiong, Y. Wu, G. Li, Y. Han and F. Chu, Industrial \& Engineering Chemistry Research, 2018, 57, 12071212.

382. M. A. Salami, F. Kaveian, M. Rafienia, S. Saber-Samandari, A. Khandan and M. Naeimi, Journal of medical signals and sensors, 2017, 7, 228.

383. C. D. Tran, H. C. Ho, J. K. Keum, J. Chen, N. C. Gallego and A. K. Naskar, Energy Technology, 2017, 5, 1927-1935.

384. N. Ponomarev, O. Pastushok, E. Repo, B. Doshi and M. Sillanpää, ACS Applied Nano Materials, 2019, 2, 5492-5503.

385. M. S. Alqahtani, A. Alqahtani, A. Al-Thabit, M. Roni and R. Syed, J. Mater. Chem. B, 2019, 7, 4461-4473.

386. M. Jafari, Z. Paknejad, M. R. Rad, S. R. Motamedian, M. J. Eghbal, N. Nadjmi and A. Khojasteh, J. Biomed. Mater. Res., Part B, 2017, 105, 431-459.

387. M. Witzler, A. Alzagameem, M. Bergs, B. E. Khaldi-Hansen, S. E. Klein, D. Hielscher, B. Kamm, J. Kreyenschmidt, E. Tobiasch and M. Schulze, Molecules, 2018, 23.

388. S. Rai, B. K. Singh, P. Bhartiya, A. Singh, H. Kumar, P. K. Dutta and G. K. Mehrotra, J. Lumin., 2017, 190, 492-503.

389. B. Xue, Y. Yang, Y. Sun, J. Fan, X. Li and Z. Zhang, Int. J. Biol. Macromol., 2019, 122, 954-961.

390. H. Yin, L. Liu, X. Wang, T. Wang, Y. Zhou, B. Liu, Y. Shan, L. Wang and X. Lü, Colloids Surf., A, 2018, 545, 51-59.

391. Z. Zhang, S. Yi, Y. Wei, H. Bian, R. Wang and Y. Min, Polymers, 2019, 11, 1946.

392. X. Ma, A. L. Smirnova and H. Fong, Mat. Sci. Eng. B-AdV., 2019, 241, 100-104.

393. S. Jha, S. Mehta, Y. Chen, P. Renner, S. S. Sankar, D. Parkinson, S. Kundu and H. Liang, J. Mater. Chem. C, 2020, 8, 3418-3430.

394. H. Li, Y. Zhao, S. Liu, P. Li, D. Yuan and C. He, Microporous Mesoporous Mater., 2020, 297, 109960.

395. S. C. Lee, E. Yoo, S. H. Lee and K. Won, Polymers, 2020, 12, 699.

396. A. Henn and M.-L. Mattinen, World J. Microbiol. Biotechnol., 2019, 35, 125. 
397. W. Yang, J. S. Owczarek, E. Fortunati, M. Kozanecki, A. Mazzaglia, G. M. Balestra, J. M. Kenny, L. Torre and D. Puglia, Ind. Crops Prod., 2016, 94, 800-811.

398. W. Yang, E. Fortunati, F. Bertoglio, J. S. Owczarek, G. Bruni, M. Kozanecki, J. M. Kenny, L. Torre, L. Visai and D. Puglia, Carbohydr. Polym., 2018, 181, 275-284.

399. W. Ding, S. H. Lee, J. Kim and C. B. Park, ChemSusChem, 2020.

400. T. Masilompane, N. Chaukura, A. K. Mishra, S. B. Mishra and B. B. Mamba, in Bio-and Nanosorbents from Natural Resources, Springer, 2018, pp. 55-73.

401. J. G. Lee, L. L. Larive, K. T. Valsaraj and B. Bharti, ACS Appl. Mater. Interfaces, 2018, 10, 43282-43289.

402. A. São Pedro, I. Santo, C. Silva, C. Detoni and E. Albuquerque, Microbial Pathogens and Strategies for Combating Them (Méndez-Vilas, A., ed.) Formatex Research Center Pulisher, 2013, 2, 1364-1374.

403. J. Jeevanandam, Y. S. Aing, Y. S. Chan, S. Pan and M. K. Danquah, in Antimicrobial nanoarchitectonics: From synthesis to applications, Elsevier, 2017, vol. 1, pp. 62-82.

404. F. Bakkali, S. Averbeck, D. Averbeck and M. Idaomar, Food Chem. Toxicol., 2008, 46, 446-475.

405. T. Hennebelle, S. Sahpaz, H. Joseph and F. Bailleul, J. Ethnopharmacol., 2008, 116, 211-222.

406. G. Belay, Y. Tariku, T. Kebede, A. Hymete and Y. Mekonnen, Phytopharmacology, 2011, 1, 133-143.

407. A. Rastogi, P. Singh, F. A. Haraz and A. Barhoum, in Fundamentals of Nanoparticles, Elsevier, 2018, pp. 571-604.

408. B. Pecha and M. Garcia-Perez, in Bioenergy, ed. A. Dahiya, Academic Press, Boston, 2015, DOI: https://doi.org/10.1016/B978-0-12-407909-0.00026-2, pp. 413-442.

409. B. Z. Sahaf, S. Moharramipour and M. H. Meshkatalsadat, Insect Sci., 2007, 14, 213-218.

410. H. S. Kusuma and M. Mahfud, RSC Adv., 2017, 7, 1336-1347.

411. J. Jeevanandam, Y. S. Chan and M. K. Danquah, ChemBioEng Rev., 2016, 3, 55-67.

412. A. Altemimi, N. Lakhssassi, A. Baharlouei, G. D. Watson and A. D. Lightfoot, Plants, 2017, 6.

413. K. Jadhav, S. Deore, D. Dhamecha, R. Hr, S. Jagwani, S. Jalalpure and R. Bohara, ACS Biomaterials Science \& Engineering, 2018, 4, 892-899.

414. S. Andra, S. K. Balu, J. Jeevanandham, M. Muthalagu, M. Vidyavathy, Y. San Chan and M. K. Danquah, Naunyn-Schmiedeberg's Arch. Pharmacol., 2019, 392, 755-771.

415. A. Goel and A. K. Bhatia, Nanoscience \& Nanotechnology-Asia, 2019, 9, 437-443.

416. V. Sanna, G. Lubinu, P. Madau, N. Pala, S. Nurra, A. Mariani and M. Sechi, Journal of agricultural and food chemistry, 2015, 63, 2026-2032.

417. M. Diaconu, S. C. Litescu and G. L. Radu, Microchimica Acta, 2011, 172, 177-184.

418. J. Jeevanandam, A. Sundaramurthy, V. Sharma, C. Murugan, K. Pal, M. H. A. Kodous and M. K. Danquah, in Sustainable Nanoscale Engineering, Elsevier, 2020, pp. 83-113.

419. R. Kumar, S. M. Roopan, A. Prabhakarn, V. G. Khanna and S. Chakroborty, Spectrochimica Acta Part A: Molecular and Biomolecular Spectroscopy, 2012, 90, 173-176.

420. A. Bankar, B. Joshi, A. R. Kumar and S. Zinjarde, Materials Letters, 2010, 64, 1951-1953.

421. C. N. H. Thuc and H. H. Thuc, Nanoscale research letters, 2013, 8, 1-10.

422. N. Ahmad, S. Sharma and R. Rai, Adv. Mater. Lett, 2012, 3, 376-380.

423. D. Kaliannan, S. Palaninaicker, V. Palanivel, M. A. Mahadeo, B. N. Ravindra and S. Jae-Jin, Environmental Science and Pollution Research, 2019, 26, 5305-5314.

424. R. S. R. El-Mohamedy, N. G. El-Gamal, A. R. El-Shamy and S. Atalla, International Journal of Agricultural Technology, 2018, 14, 833-844.

425. P. R. Ghosh, D. Fawcett, S. B. Sharma and G. E. J. Poinern, Materials, 2017, 10, 852.

426. S. Sinsinwar, M. K. Sarkar, K. R. Suriya, P. Nithyanand and V. Vadivel, Microbial pathogenesis, 2018, 124, 30-37.

427. I. A. Adelere and A. Lateef, Nanotechnology Reviews, 2016, 5, 567-587.

428. P. Sudhakar and H. Soni, Journal of environmental chemical engineering, 2018, 6, 28-36.

429. S. Rovani, J. J. Santos, P. Corio and D. A. Fungaro, ACS omega, 2018, 3, 2618-2627.

430. A. Zamani, A. P. Marjani and Z. Mousavi, Green Processing and Synthesis, 2019, 8, 421-429.

431. G. E. J. Poinern and D. Fawcett, Harnessing Nanoscale Surface Interactions: Contemporary Synthesis, Applications and Theory, 2019. 
432. G. Gahlawat and A. R. Choudhury, RSC Adv., 2019, 9, 12944-12967.

433. A. Dzimitrowicz, S. Berent, A. Motyka, P. Jamroz, K. Kurcbach, W. Sledz and P. Pohl, Arabian Journal of Chemistry, 2019, 12, 4795-4805.

434. R. P. Ghosh, D. Fawcett, B. S. Sharma and E. J. G. Poinern, Materials, 2017, 10.

435. K. Vijayaraghavan, S. P. K. Nalini, N. U. Prakash and D. Madhankumar, Colloids Surf., B, 2012, 94, 114117.

436. C. Jayaseelan, A. A. Rahuman, G. Rajakumar, A. Vishnu Kirthi, T. Santhoshkumar, S. Marimuthu, A. Bagavan, C. Kamaraj, A. A. Zahir and G. Elango, Parasitol. Res., 2011, 109, 185-194.

437. T. Santhoshkumar, A. A. Rahuman, G. Rajakumar, S. Marimuthu, A. Bagavan, C. Jayaseelan, A. A. Zahir, G. Elango and C. Kamaraj, Parasitol. Res., 2011, 108, 693-702.

438. M. Govindarajan, M. Rajeswary, K. Veerakumar, U. Muthukumaran, S. L. Hoti, H. Mehlhorn, D. R. Barnard and G. Benelli, Parasitol. Res., 2016, 115, 723-733.

439. M. Govindarajan, M. Rajeswary, K. Veerakumar, U. Muthukumaran, S. L. Hoti and G. Benelli, Exp. Parasitol., 2016, 161, 40-47.

440. D. S. Sheny, J. Mathew and D. Philip, Spectrochim. Acta, Part A, 2012, 97, 306-310.

441. S. P. Dubey, M. Lahtinen and M. Sillanpää, Process Biochem., 2010, 45, 1065-1071.

442. S. M. Ghoreishi, M. Behpour and M. Khayatkashani, Phys. E, 2011, 44, 97-104.

443. M. Irfan, T. Ahmad, M. Moniruzzaman, S. Bhattacharjee and B. Abdullah, Arabian J. Chem., 2020, 13, 75-85.

444. J. Ying, Y. Zheng, H. Zhang and L. Fu, Rev. Mex. Ing. Quim., 2020, 19, 585-592.

445. B. Şahin, A. Aygün, H. Gündüz, K. Şahin, E. Demir, S. Akocak and F. Şen, Colloids Surf., B, 2018, 163, 119-124.

446. N. S. Al-Radadi, Arabian J. Chem., 2019, 12, 330-349.

447. A. A. Olajire, G. O. Adeyeye and R. A. Yusuf, J. Cluster Sci., 2017, 28, 1565-1578.

448. V. Vilas, D. Philip and J. Mathew, Mater. Chem. Phys., 2016, 170, 1-11.

449. K. Tahir, S. Nazir, A. Ahmad, B. Li, S. A. Ali Shah, A. U. Khan, G. M. Khan, Q. U. Khan, Z. U. Haq Khan and F. U. Khan, RSC Adv., 2016, 6, 85903-85916.

450. A. J. Kora and L. Rastogi, Ind. Crops Prod., 2016, 81, 1-10.

451. B. Siripireddy and B. K. Mandal, Adv. Powder Technol., 2017, 28, 785-797.

452. N. Sachudanandam, D. Shakila, K. Geetha and A. Dinesh Karthik, IOSR J Pharm, 2017, 2, 01-06.

453. P. Kumari, H. Kumar, J. Kumar, M. Sohail, K. Singh and K. Prasad, Int. J. Nano Dimens., 2019, 10, 320329.

454. D. Hassan, A. T. Khalil, J. Saleem, A. Diallo, S. Khamlich, Z. K. Shinwari and M. Maaza, Artif. Cells, Nanomed., Biotechnol., 2018, 46, 693-707.

455. A. Izadi, R. Safaeijavan, E. Moniri and S. A. Alavi, Int. J. Bio-Inorg. Hybrid Nanomater., 2018, 7, 71-78.

456. I. Bibi, N. Nazar, S. Ata, M. Sultan, A. Ali, A. Abbas, K. Jilani, S. Kamal, F. M. Sarim, M. I. Khan, F. Jalal and M. Iqbal, J. Mater. Res. Technol., 2019, 8, 6115-6124.

457. R. Dobrucka, Iran. J. Pharm. Res., 2017, 16, 756-762.

458. R. D. A. Jalill, Journal, 2018, 12, 678-687.

459. S. Marimuthu, A. A. Rahuman, C. Jayaseelan, A. V. Kirthi, T. Santhoshkumar, K. Velayutham, A. Bagavan, C. Kamaraj, G. Elango, M. Iyappan, C. Siva, L. Karthik and K. V. B. Rao, Asian Pac. J. Trop. Med., 2013, 6, 682-688.

460. A. TermehYousefi, S. Bagheri, K. Shinji, J. Rouhi, M. Rusop Mahmood and S. Ikeda, BioMed Res. Int., 2014, 2014.

461. Z. A. Hamid, A. A. Azim, F. A. Mouez and S. S. A. Rehim, J. Anal. Appl. Pyrolysis, 2017, 126, 218-229.

462. A. Al-Jumaili, P. Mulvey, A. Kumar, K. Prasad, K. Bazaka, J. Warner and M. V. Jacob, Sci. Rep., 2019, 9, 1-16.

463. A. J. Santos, L. T. S. Pina, J. G. Galvão, G. G. G. Trindade, R. K. V. Nunes, J. S. Santos, C. P. Santos, J. K. M. C. Gonsalves, A. A. M. Lira, S. C. H. Cavalcanti, R. L. C. Santos, V. H. V. Sarmento and R. S. Nunes, Appl. Clay Sci., 2020, 185, 105394. 
464. S. Azizi, R. Mohamad, R. A. Rahim, A. B. Moghaddam, M. Moniri, A. Ariff, W. Z. Saad and F. Namvab, Appl. Surf. Sci., 2016, 384, 517-524.

465. S. Allahvaisi, K. T. Jahromi, S. Imani and M. Khanjani, J. Plant Prot. Res., 2017, 57, 72-80.

466. L. Lin, Y. Dai and H. Cui, Carbohydrate polymers, 2017, 178, 131-140.

467. K. Munhuweyi, O. J. Caleb, A. J. van Reenen and U. L. Opara, LWT, 2018, 87, 413-422.

468. Z. Zhang, X. Wang, M. Gao, Y. Zhao and Y. Chen, Cellulose, 2020, 1-13.

469. J. R. R. Amado, A. L. Prada, J. G. Diaz, R. N. P. Souto, J. C. E. Arranz and T. P. de Souza, Environmental Science and Pollution Research, 2020, 1-14.

470. P. Alam, M. J. Ansari, M. K. Anwer, M. Raish, Y. K. T. Kamal and F. Shakeel, Artificial cells, nanomedicine, and biotechnology, 2017, 45, 591-597.

471. P. J. P. Espitia, C. A. Fuenmayor and C. G. Otoni, Compr. Rev. Food Sci. Food Saf., 2019, 18, 264-285.

472. H. Hashemi Gahruie, E. Ziaee, M. H. Eskandari and S. M. H. Hosseini, Carbohydrate Polymers, 2017, 166, 93-103.

473. R. Moghimi, L. Ghaderi, H. Rafati, A. Aliahmadi and D. J. McClements, Food Chemistry, 2016, 194, 410415.

474. H. Hazrati, M. J. Saharkhiz, M. Niakousari and M. Moein, Ecotoxicology and Environmental Safety, 2017, 142, 423-430.

475. V. Ghosh, A. Mukherjee and N. Chandrasekaran, Asian J. Chem., 2013, 25, S321.

476. O. Campolo, A. Cherif, M. Ricupero, G. Siscaro, K. Grissa-Lebdi, A. Russo, L. M. Cucci, P. Di Pietro, C. Satriano and N. Desneux, Scientific reports, 2017, 7, 1-10.

477. J. K. U. Ling, Y. S. Hii, J. Jeevanandam, Y. S. Chan and M. K. Danquah, in Phytochemistry: An in-silico and in-vitro Update, Springer Singapore, 2019, vol. 1, pp. 315-330.

478. J. O. W. González, E. N. Jesser, C. A. Yeguerman, A. A. Ferrero and B. F. Band, Environmental Science and Pollution Research, 2017, 24, 17006-17015.

479. S. P. de Matos, L. G. Lucca and L. S. Koester, Talanta, 2019, 195, 204-214.

480. H. Chen, W. Wang, J. C. Martin, A. J. Oliphant, P. A. Doerr, J. F. Xu, K. M. DeBorn, C. Chen and L. Sun, ACS Sustainable Chem. Eng., 2013, 1, 254-259.

481. V. H. Le, C. N. H. Thuc and H. H. Thuc, Nanoscale Res. Lett., 2013, 8, 58.

482. S. Bose, M. A. Ganayee, B. Mondal, A. Baidya, S. Chennu, J. S. Mohanty and T. Pradeep, ACS Sustainable Chem. Eng., 2018, 6, 6203-6210.

483. S. Sekar, T. A. Aqueel Ahmed, I. A. Inamdar, Y. Lee, H. Im, Y. D. Kim and S. Lee, Nanomaterials, 2019, 9.

484. D. P. Wong, R. Suriyaprabha, R. Yuvakumar, V. Rajendran, Y.-T. Chen, B.-J. Hwang, L.-C. Chen and K.H. Chen, J. Mater. Chem. A, 2014, 2, 13437-13441.

485. Y. Zhang, X. Song, P. Zhang, H. Gao, C. Ou and X. Kong, Chemosphere, 2020, 245, 125587.

486. A. Olad, H. Gharekhani, A. Mirmohseni and A. Bybordi, Polym. Bull., 2017, 74, 3353-3377.

487. V.-w. Ramasamy, KSCE J. Civ. Eng., 2012, 16, 93-102.

488. S. Wagner, A. Gondikas, E. Neubauer, T. Hofmann and F. von der Kammer, Angew. Chem., Int. Ed., 2014, 53, 12398-12419.

489. J. Jeevanandam, A. Barhoum, Y. S. Chan, A. Dufresne and M. K. Danquah, Beilstein J. Nanotechnol., 2018, 9, 1050-1074.

490. A. Rahman, S. Kumar and T. Nawaz, in Microalgae Cultivation for Biofuels Production, Elsevier, 2020, pp. 265-279.

491. I. Fierascu, I. C. Fierascu, R. I. Brazdis, A. M. Baroi, T. Fistos and R. C. Fierascu, Materials, 2020, 13, 574.

492. S. Soman and J. G. Ray, Recent Trends in Nanomedicine and Tissue Engineering, 2017, 249.

493. Y.-W. Huang, M. Cambre and H.-J. Lee, Int. J. Mol. Sci., 2017, 18, 2702.

494. M. Ovais, A. T. Khalil, N. U. Islam, I. Ahmad, M. Ayaz, M. Saravanan, Z. K. Shinwari and S. Mukherjee, Appl. Microbiol. Biotechnol., 2018, 102, 6799-6814.

495. K. Gudikandula and S. Charya Maringanti, J. Exp. Nanosci., 2016, 11, 714-721.

496. A. Kędziora, K. Gorzelańczyk and G. Bugla-Płoskońska, Biol. Int., 2013, 53, 67-76.

497. J. Overmann and A. H. Scholz, Trends Microbiol., 2017, 25, 85-88. 
498. A. Abdelmoteleb, B. Valdez-Salas, M. Carrillo-Beltran, D. D. Hernandez and D. González-Mendoza, Iran. J. Sci. Technol. A, 2018, 42, 457-463. 